\title{
Effects of subclinical hyperthyroidism on bone and heart
}

Citation for published version (APA):

Mudde, A. H. (1993). Effects of subclinical hyperthyroidism on bone and heart. [Doctoral Thesis, Maastricht University]. Rijksuniversiteit Limburg. https://doi.org/10.26481/dis.19930902am

Document status and date:

Published: 01/01/1993

DOI:

10.26481/dis.19930902am

Document Version:

Publisher's PDF, also known as Version of record

\section{Please check the document version of this publication:}

- A submitted manuscript is the version of the article upon submission and before peer-review. There can be important differences between the submitted version and the official published version of record.

People interested in the research are advised to contact the author for the final version of the publication, or visit the DOI to the publisher's website.

- The final author version and the galley proof are versions of the publication after peer review.

- The final published version features the final layout of the paper including the volume, issue and page numbers.

Link to publication

\footnotetext{
General rights rights.

- You may freely distribute the URL identifying the publication in the public portal. please follow below link for the End User Agreement:

www.umlib.nl/taverne-license

Take down policy

If you believe that this document breaches copyright please contact us at:

repository@maastrichtuniversity.nl

providing details and we will investigate your claim.
}

Copyright and moral rights for the publications made accessible in the public portal are retained by the authors and/or other copyright owners and it is a condition of accessing publications that users recognise and abide by the legal requirements associated with these

- Users may download and print one copy of any publication from the public portal for the purpose of private study or research.

- You may not further distribute the material or use it for any profit-making activity or commercial gain

If the publication is distributed under the terms of Article $25 \mathrm{fa}$ of the Dutch Copyright Act, indicated by the "Taverne" license above, 


\section{EFFECTS OF SUBCLINICAL}

HYPERTHYROIDISM ON BONE AND HEART 
() AH MUDDE, DOETINCHEM 1993

\section{CIP DATA KONINKLIJKE BIBLIOTHEEK DEN HAAG}

Mudde, Aart Hendrik

Effects of subclinical hyperthyroidism on bone and heart / Aart Hendrik Mudde. - [S.I. : s.n.]. - III.

Thesis Maastricht. - With ref. - With summary in Dutch. ISBN 90-9006340-4

Subject headings: hyperthyroidism / osteoporosis

Produktion: Datawyse I Universitaire Pers Maastricht

The publication of this thesis was supported by grants from Organon Nederland bv and Novo Nordisk Farma bv, the Netherlands. 


\title{
EFFECTS OF SUBCLINICAL HYPERTHYROIDISM ON BONE AND HEART
}

\author{
Invloed van subklinische hyperthyreoïdie \\ op het bot en het hart
}

\author{
PROEFSCHRIFT \\ ter verkrijging van de graad van doctor \\ aan de Rijksuniversiteit Limburg te Maastricht, \\ op gezag van de Rector Magnificus, Professor Mr. M.J. Cohen, \\ volgens het besluit van het College van Dekanen, \\ in het openbaar te verdedigen \\ op donderdag 2 september 1993 om 16.00 uur \\ door
}

Aart Hendrik Mudde

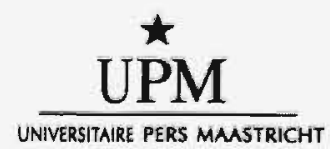


Promotor:

Prof.dr. A.C. Nieuwenhuijzen Kruseman

Beoordelingscommissie:

Prof.dr. J.L.H. Evers (voorzitter)

Dr. M.P. van Dieijen-Visser (De Weverziekenhuis, Heerlen)

Dr. J.W.F. Elte (St. Franciscus Ziekenhuis, Rotterdam)

Prof.dr. A.J. van der Linden

Dr. S.E. Papapoulos (Rijksuniversiteit Leiden, Leiden)

Dr. C. Vermeer

The studies described in this thesis have been performed in the Department of Internal Medicine, Slingeland Ziekenhuis, Doetinchem, The Netherlands. 


\section{Paranimfen:}

Dr. F.J.L. Reijnders

Drs. H. Drost

If you don't know where you are going, you will probably end up somewhere else.

Laurence J. Peter, 1969. 


\section{ABBREVIATIONS AND SYMBOLS}

$\begin{array}{ll}\text { ANOVA } & \text { Analysis Of Variance } \\ \text { BGP } & \text { Bone-Gla-Protein } \\ \text { BMC } & \text { Bone Mineral Content } \\ \text { BMD } & \text { Bone Mineral Density } \\ \text { DBMC/BW } & \text { Ratio of Distal Bone Mineral Content to Bone Width } \\ \Delta & \text { Delta = change in value of parameter } \\ \text { DEXA } & \text { Dual Energy X-ray Absorptiometry } \\ \text { ECG } & \text { Electro Cardiogram } \\ \text { EG } & \text { Euthyroid goitre } \\ \text { FT4 } & \text { Free Thyroxine } \\ \text { FTI } & \text { Free Thyroxine Index } \\ \text { Gla } & \text { Gamma-carboxyglutamate } \\ \text { 125I } & \text { 125-Isotope of Iodine } \\ \text { ICMA } & \text { Immuno-Chemilumino-Metric-Assay } \\ \text { IEMA } & \text { Immuno-Enzymmometric-Assay } \\ \text { IFMA } & \text { Immuno-Fluorometric-Assay } \\ \text { IMA } & \text { Immuno-Metric-Assay } \\ \text { IRMA } & \text { Immuno-Radio-Metric-Assay } \\ \text { LDL cholesterol } & \text { Low Density Lipoprotein fraction of cholesterol } \\ \text { Log } & \text { Logarithm } \\ \text { L-thyroxine } & \text { Levothyroxine } \\ \text { LVET } & \text { Left Ventricular Ejection Time } \\ \text { N } & \text { Number } \\ \text { P } & \text { Probability } \\ \text { PBMC/BW } & \text { Ratio of Proximal Bone Mineral Content to Bone Width } \\ \text { PEP } & \text { Pre-Ejection-Period } \\ \text { Pr } & \text { Prevalence } \\ \text { PTH } & \text { Parathyroid Hormone } \\ \text { RIA } & \text { Radio-Immuno-Assay } \\ \text { SD } & \text { Standard Deviation } \\ \text { Se } & \text { Sensitivity } \\ \text { SEM } & \text { Standard Error of the Mean } \\ \text { SHBG } & \text { Sex Hormone Binding Globuline } \\ \text { SHG } & \text { Subclinical Hyperthyroid Goitre } \\ \text { Sp } & \text { Specificity } \\ \text { SPA } & \text { Single Photon Absorptiometry } \\ \text { T3 } & \text { Triiodothyronine } \\ \text { T4 } & \text { Thyroxine } \\ \text { 99m Tc } & \text { 99 Metastabile Isotope of Technetium } \\ \text { TRH } & \text { Thyrotrop(h)in Releasing Hormone } \\ \text { TSH } & \text { Versus Stimulating Hormone } \\ \text { Vs } & \end{array}$




\section{CONTENTS}

1. INTRODUCTION

Aim and outline of the study $\quad 9$

1.1 Aim of the study 10

1.2 The concept of subclinical hyperthyroidism 10

1.3 TSH-assays 11

1.4 Thyroid hormones and bone metabolism $\quad 12$

1.5 Osteocalcin 14

1.6 Thyroid hormones and the heart 15

1.7 Design of the study 16

2. TSH-IRMA AS FIRST-LINE THYROID FUNCTION TEST IN SUSPECTED HYPERTHYROIDISM

3. RELATIONS BETWEEN OSTEOCALCIN, FOREARM BONE MINERAL DENSITY, THYROID FUNCTION, AGE AND BODY MASS IN HEALTHY WOMEN

4. PERIPHERAL BONE DENSITY IN WOMEN WITH UNTREATED MULTINODULAR GOITRE

5. BONE TURNOVER IN WOMEN WITH SUBCLINICAL HYPERTHYROID MULTINODULAR GOITRE

6. SYSTOLIC TIME INTERVALS AND HEART RATE IN WOMEN WITH UNTREATED MULTINODULAR GOITRE

7. BONE METABOLISM DURING THYROSTATIC TREATMENT OF SUBCLINICAL HYPERTHYROIDISM 
8. GENERAL DISCUSSION 85

8.1 Introduction 86

8.2 TSH and thyroid hormones 86

8.3 Some metabolic variables $\quad 88$

8.4 Bone turnover $\quad 88$

8.5 Bone density 90

8.6 The Heart 94

8.7 Thyrostatic treatment 95

8.8 Conclusions 96

9. SUMMARY 110

$\begin{array}{ll}\text { SAMENVATTING } & 113\end{array}$

$\begin{array}{ll}\text { NAWOORD } & 117\end{array}$

$\begin{array}{ll}\text { CURRICULUM VITAE } & 119\end{array}$ 
Chapter 1

\section{INTRODUCTION}

AIM AND OUTLINE OF THE STUDY 


\subsection{AIM OF THE STUDY}

A substantial proportion of subjects with clinically euthyroid goitre expose suppressed serum TSH levels together with normal serum levels of thyroid hormones. The objective of this study was to explore some clinical consequences of this socalled "subclinical hyperthyroidism".

\subsection{THE CONCEPT OF SUBCLINICAL HYPERTHYROIDISM}

By definition thyrotoxicosis appears when the level of thyroid hormones in target tissues exceeds the individuals demands (Wiersinga and Krenning, 1988). There is a tight feedback between the thyroid gland and the pituitary, which is illustrated by a close inverse relationship between serum TSH and serum T4 (Spencer et al., 1990). In overt thyrotoxicosis elevated serum levels of thyroid hormones are combined with a flat TSH response after stimulation by TRH (Ormston et al., 1971).

The condition characterized by TRH-resistant suppression of TSH together with normal serum levels of thyroid hormones is defined as "preclinical" or "subclinical" thyrotoxicosis (Evered et al., 1974, Gemsenjäger et al., 1976, Gemsenjäger et al., 1983). Subclinical thyrotoxicosis may be exogenous as a consequence of L-thyroxine treatment, or it may arise spontaneously (Ross, 1991b). This endogenous subclinical hyperthyroidism is most common in multinodular goitre (Tenerz et al., 1990). In this condition varying degrees of functional autonomy within the thyroid gland have been established by the absence of suppressibility of the uptake of radioactive iodine after T3 administration (Miller and Block, 1970, Smeulers et al., 1977, Wiarda et al., 1978). Multinodular goitre is functionally a graded condition in which euthyroidism may slowly progress through a state of autonomy to hyperthyroidism (Miller and Block, 1970, Studer et al., 1978, Studer et al., 1985, Elte et al., 1990, Berghout et al., 1990). This process takes many years (Elte et al., 1990). The functional state of autonomy in multinodular goitre is thus identical with "preclinical" or "subclinical" hyperthyroidism (Elte et al., 1982).

In the seventies much confusion has arised from discrepancies between T3-suppressibility and the results of TRH-testing in subclinical hyperthyroidism (Elte, 1977, Smeulers et al., 1977, Emrich and Bähre, 1978). The wide availability of more sensitive TSH-assays in the beginning of the eighties have given a new impulse to the outlining and investigation of subclinical thyrotoxicosis. 


\subsection{TSH-ASSAYS}

In the eighties the sensitive immunometric assays (IMA's) for TSH have rapidly replaced the single antibody radio-immuno assays (RIA's) in clinical practice. The improved sensitivity of these assays largely results from the "sandwich"principle, in which two anti-TSH antibodies, usually monoclonal, are employed (Nicoloff and Spencer, 1990). The first antibody, bound to a solid phase, is directed at the specific subunit of TSH and selectively extracts TSH. The bound TSH is further quantified by a labeled antibody. The label employed could either be a radioactive molecule $\left({ }^{125} \mathrm{I}\right)$, as in the immuno-radiometric assays (IRMA's), a fluorophor (immuno-fluorometric assay (IFMA)), an enzyme (immuno- enzymmometric assay, (IEMA)) or a chemiluminescent molecule (immuno-chemiluminometric assay (ICMA)) (Nicoloff and Spencer, 1990, Hashimoto et al, 1991).

A Nomenclature Committee of the American Thyroid Association has stated that a minimal requirement for the predicate "sensitive" of a TSH assay should be that the serum from clinically hyperthyroid patients will give results that are more than three log SD below the mean value found in serum from normal subjects (Larsen et al., 1987). Extended criteria for a sensitive TSH assay to be used as a first line thyroid function test have been proposed by one of the members of the Committee (Klee and Hay, 1987):

1) A sensitive TSH assay should have less than $1 \%$ overlap between the variation of the lower reference value limit and the assay detection limit.

2) At least $95 \%$ of patients with a subnormal TSH response to TRH stimulation should have basal TSH values below the lower normal value limit.

3) At least $95 \%$ of patients who have a normal TSH response to TRH stimulation should have a detectable basal TSH concentration.

4) At least $95 \%$ of hyperthyroid subjects should have values below the assay detection limit.

5) At least $95 \%$ of clinical euthyroid subjects should have a detectable basal TSH concentration.

Further discrimination between the TSH assays has been performed on the base of the detection limits of the various assays (Wood et al., 1985, Kreutzer et al., 1986, Wilke and Utley, 1988, Spencer et al., 1990). From this point of view TSH-RIA's are "first generation" assays. Each new generation of TSH assays is demarkated from the previous one by a 10-fold increase in functional sensitivity (Spencer et al., 1990). Up to now 3 generations of TSH assays have been defined.

In euthyroidism and various thyroid disorders, including thyroid autonomy, basal TSH values, measured with a sensitive assay, appear to be highly predic- 
tive for the outcome of TRH-tests (Seth et al., 1984, Caldwell et al., 1985, Gow et al., 1986, Wiersinga et al.,1986, Lind et al., 1988, John et al., 1989, v. Hamersvelt et al., 1989, Ross et al., 1989a). However, basal TSH may be misleading in several conditions, like pituitary disease, depression, major nonthyroidal illness, usage of several medications and in eldery people (Krenning and Hennemann, 1986, Hennemann et al., 1987, Larsen et al., 1987, Ehrmann et al., 1989, Bartalena et al., 1990, Nicoloff and Spencer, 1990, Surks et al., 1990, Szaboles et al., 1990, Ross et al., 1990, Sawin et al., 1991, DeGroot et al., 1992).

In multinodular goitre a substantial proportion of subjects is detected with suppressed basal TSH values and normal serum levels of thyroid hormones (Gibold et al, 1986, Caldwell et al., 1987, Lind et al., 1988, Ross et al., 1989a, Tenerz et al., 1990) The prevalence of subclinical hyperthyroidism in multinodular goitre, however, is not well established; some reported figures are rather high, ranging from 15 to 55\% (Gemsenjäger et al., 1976, Elte et al., 1977, Emrich and Bähre, 1978, Berghout et al., 1990). These figures, however, are based on hospital surveillances, which are most probably biased by selection. The prevalence of subclinical hyperthyroidism in more randomly selected populations is estimated at about $2 \%$, being higher in eldery than in younger people (Tenerz et al., 1990, Parle et al., 1991).

\subsection{THYROID HORMONES AND BONE METABOLISM}

In 1891 a 23 years old women, named Rosalie Gebus, has been described by Von Recklinghausen with severe decalcification of the bones due to hyperthyroidism (Von Recklinghausen, 1891). This is probably the first description of the association between osteoporosis and hyperthyroidism. In 1937 Snapper has described 2 patients with only mild hyperthyroidism and severe painful osteoporosis, which improved after subtotal thyroidectomy (Snapper, 1937).

Histomorphometric studies of bone in hyperthyroidism have revealed increased osteoclastic as well as osteoblastic activity both in cortical and in trabecular bone (Meunier et al., 1972, Melsen and Mosekilde, 1977, Eriksen et al., 1985). The mineralization rate in thyrotoxic bone is increased and the lag time between osteoblastic apposition and osteoid mineralization is decreased, resulting in a decrease in osteoid seam width (Eriksen et al., 1985). Reconstruction of the remodeling sequences have revealed a marked shortening of the bone remodeling cycle and an increased activation frequency of remodeling cycles in hyperthyroidism (Eriksen, 1986). These data indicate that the coupling of bone formation and resorption in hyperthyroidism is undisturbed, and that hyper- 
thyroid bone disease is predominantly characterized by increased bone turnover. Relative to the osteoclasts the osteoblasts, however, are supposed to be less active, resulting in a negative balance between bone formation and resorption (Meunier et al., 1972, Melsen and Mosekilde 1977, Eriksen et al., 1985). From histomorphometric observations Meunier et al. (1972) have concluded that the impact of the bony manifestations in hyperthyroidism is related more to the duration rather than to the severity of the thyrotoxicosis.

The increased bone turnover in hyperthyroidism is associated with an increase in the serum concentration of alkaline phosphatase (Mosekilde et al., 1978, Cooper et al., 1979, Bijlsma et al., 1983, Hyldstrup et al., 1988, Tibi et al., 1989) and in the urinary excretion of hydroxyproline (Kivirikko et al., 1965, Siersbaek-Nielsen et al., 1971, Mosekilde et al., 1978, Hendriks et al., 1979, Bijlsma et al., 1983). The renal tubular resorption of calcium in hyperthyroidism may be decreased (Mosekilde et al., 1977), which, together with an increased efflux of calcium from bone (Hendriks et al., 1977), may result in hypercalciuria. Serum PTH levels in hyperthyroidism are often in the low-normal range, probably as a result of the slight increase in serum calcium due to the effect of thyroid hormones on calcium resorption from bone (Mosekilde et al., 1977, Tibi et al., 1989, Ross et al., 1989b). The observed decline in serum 1,25dihydroxyvitamin D3 concentrations, with unaltered 25- hydroxyvitamin D3 concentrations, in hyperthyroidism is probably also mediated by feedback regulation, induced by the slight increase in serum calcium and the suppressed PTH. (Bouillon et al., 1980, Jastrup et al., 1982, Peerenboom et al., 1984). The decline in 1,25-dihydroxyvitamin D3 formation results in decreased intestinal calcium absorption in hyperthyroid patients (Peerenboom et al., 1984). A direct effect on bone resorption of both $\mathrm{T} 4$ and $\mathrm{T} 3$ has been documented in vitro by calcium kinetic studies, histology and hydroxyproline concentrations in cultured fetal rat bones (Mundy et al., 1976). The probability of the existence of a nuclear thyroid hormonal receptor in osteoblasts in human is supported by its demonstration in osteoblastlike osteosarcoma cells in vitro (Rizolli et al., 1986, Sato et al., 1987).

The introduction of reliable methods of noninvasive measurement of bone density has given a new dimension to the investigation of hyperthyroid bone disease. Decreased bone density in hyperthyroidism has been documented by single and dual photon absorptiometry and by dual energy X-ray absorptiometry (DEXA) both in the peripheral and in the axial skeleton (Fraser, 1971, Linde and Friis, 1979, Krølner et al.,1983, Toh et al., 1985, Lee et al., 1990, Wakasugi et al., 1993). An increased fracture risk in relation to decreased forearm bone density in hyperthyroidism has been documented already 20 years ago (Fraser et al., 1971). 
Recently new biochemical parameters of bone turnover have become available, with greater sensitivity and specificity than the classical parameters like alkaline phosphatase and hydroxyproline. One of the first of these parameters was osteocalcin, which is extensively explored in relation to subclinical hyperthyroidism in this study.

\subsection{OSTEOCALCIN}

Osteocalcin is a calcium binding protein that contains three residues of the vitamin $\mathrm{K}$ dependent amino-acid, gamma-carboxyglutamic acid (Price et al., 1980a, Vermeer, 1990). This protein has been discovered first in chicken bone (Hauschka et al., 1975) and in bovine bone (Price et al., 1976), followed by its identification in human bone (Vermeulen et al., 1989). Osteocalcin, also called bone Gla-protein (BGP), is produced by osteoblasts (Nishimoto et al., 1980, Kaplan et al., 1985). 1,25-Dihydroxyvitamin D3 is the main stimulator of osteocalcin production (Beresford et al., 1984, Morrison et al., 1989, Lian et al., 1989, Markose et al., 1990, Nielsen et al., 1991). Thyroid hormones, however, also appear to influence osteocalcin metabolism. A direct effect of $\mathrm{T} 3$ on osteocalcin secretion has been documented in vitro (Rizolli et al., 1986). Osteocalcin probably plays a major role in the process of intercellular interaction between osteoblasts and osteoclasts (Glowacki et al., 1991, DeFranco et al., 1991).

A bovine radio-immuno assay that cross-reacts with human osteocalcin has been developed in the late seventies (Price and Nishimoto, 1980). This has been followed by a radio-immuno assay against a synthetic human osteocalcin fraction (Jüppner et al., 1986), but only recently a monoclonal antibody raised against human osteocalcin has been developed (Ohta et al., 1991, Kanzaki et al., 1992). Most of the clinical studies available on osteocalcin up to now are performed with (polyclonal) radio-immuno assays against bovine osteocalcin.

Serum osteocalcin levels vary with sex and aging (Delmas et al., 1983a, Epstein et al., 1984, Delmas et al., 1986, Duda et al., 1988, Worsfold et al., 1988, Ruffie et al., 1989, Vanderschueren et al., 1990, Tarallo et al., 1990, Orwoll et al., 1990). A diurnal fluctuation of serum osteocalcin in humans, with maximum levels during the night and lowest levels in the morning, is well documented (Gundberg et al., 1985, Nielsen et al., 1990a, Pietschmann et al., 1990, Nielsen et al., 1992). A seasonal variation in osteocalcin has been reported in some studies (Thomsen et al., 1989, Nielsen et al., 1990b), but these data have not been supported by others (Overgaard et al., 1988, Vanderschueren et al., 1991). 
Serum osteocalcin levels are influenced by several other factors, like vitamin K status and alcohol-intake (Knapen et al., 1989, Nielsen et al., 1990c). Increased serum osteocalcin levels in renal failure are probably due to both decreased osteocalcin clearence and increased bone turnover (Delmas et al., 1983b, Farrugia et al., 1991). A considerable discrepancy exists between the normal reference limits of serum osteocalcin, given by different investigators, which makes comparison of absolute values of osteocalcin in reported clinical studies impossible (Delmas et al., 1983a, Epstein et al., 1984, Delmas et al., 1986, Duda et al., 1988, Worsfold et al., 1988, Ruffie et al., 1989, Vanderschueren et al., 1990, Tarallo et al., 1990, Orwoll et al., 1990). This might partly be due to structural variation in osteocalcin which might influence the antibody binding and partly to differences in assay-performance (Jüppner et al., 1986, Knapen et al., 1989, Delmas et al., 1990, Tracy et al., 1990). Therefore, it has been advocated in an "Assay Standardization Report on osteocalcin" to express individual values of osteocalcin as a percentage of serum osteocalcin in an appropriate population of normal individuals (Delmas et al., 1990).

Although basicly a parameter of osteoblastic function, osteocalcin has been shown to be a good parameter of bone turnover in steady state situations in which coupling between osteoblastic and osteolastic activity is intact (Delmas et al., 1990). In hyperthyroidism the serum osteocalcin concentration is correlated both with the serum alkaline phosphatase concentration and the urinary hydroxyproline-excretion (Garrel et al., 1986, Martinez et al., 1986, Popelier et al., 1990). This indicates that in this condition the serum osteocalcin concentration reflects the rate of bone turnover, which is increased in hyperthyroidism (Lukert et al, 1986, Garrel et al., 1986, Martinez et al., 1986, Popelier et al., 1990, Lee et al., 1990). The elevated levels of serum osteocalcin in hyperthyroidism coincide with reduced bone density (Lee et al., 1990, Wakasugi et al., 1993).

\subsection{THYROID HORMONES AND THE HEART}

Thyroid hormones have profound effects on the cardiac function. These effects are mediated both by direct and indirect mechanisms. Animal studies, some of which have been summerized by Oppenheimer (1991), have documented the expression of genes coding for the thyroid hormone receptor in cardiac tissue. Recently the thyroid hormone receptor has been characterized in a human cell line (Weinberger et al., 1986).

Thyroid hormones have a chronotrope influence by a direct effect on sinus node function. This has been demonstrated in vivo by the observation that in 
hyperthyroid patients the resting heart rate remains elevated after complete autonomic blockade with propranolol plus atropine (Valcavi et al., 1992).

Myocardiac contractility is enhanced under the influence of thyroid hormones (Fitzsimons et al., 1990). Clinically this is reflected by a decreased isovolumetric contraction time (time between mitral valve closure and aortic valve opening or beginning of carotid pulse) and a decreased pre-ejection period ( $\mathrm{PEP}=$ time between electric activation and aortic valve opening, respectively beginning of carotid pulse) in hyperthyroidism, as has been first demonstrated by simultaneous recording of carotid pulse, phonocardiogram and electrocardiogram (ECG) (Amidi et al., 1968, Parisi et al., 1974), and later by simultanous recordings of echocardiography and ECG (Lewis et al., 1979, Friedman et al., 1982, Tseng et al., 1989). These phenomena are unaltered by $\beta$-blockade (Grossman et al., 1971, Lien and Aanderund, 1982).

The left ventricular ejection time (LVET = time between aortic valve opening and closure) in hyperthyroidism may be shortened. Because of the opposite effects of thyroid hormones on PEP and LVET the ratio between PEP and LVET gives a more pronounced expression of the altered cardic performance in thyroid disease (Lewis et al., 1979, Tseng et al,, 1989). Correction for increased heart rate of the declined PEP/LVET ratio does not essentially alter the findings in hyperthyroidism (Tseng et al., 1989). PEP/LVET ratios have been shown to reflect the thyroid functional status over a wide range of thyroid function from hypothyroidism to hyperthyroidism (Crowley et al., 1977, Tseng et al., 1989, Price et al., 1991).

Thyroid hormone excess also alters diastolic performance, resulting in a shortened isovolumetric relaxation time, and an increased velocity of diastolic filling (Friedman et al., 1982, Mintz et al., 1991).

Part of the altered cardiac performance of thyroid hormone excess may be due to altered catecholaminergic function as well, but much confusion about the extend and pathways of this possibility still remains (Levey et al., 1990).

\subsection{DESIGN OF THE STUDY}

Most of the studies on the pathophysiologic effects of sublinical thyrotoxicosis have been performed in L-thyroxine treated subjects. The present study deals with untreated spontaneous (endogenous) subclinical hyperthyroidism. The investigations are focused on two target organs for thyroid hormones with different metabolic and functional characteristics, i.e. the bone, in which changing metabolic influences are expressed slowly and the heart, in which the functional status can alter very quickly. 
Multinodular goitre was defined as the subject of interest, as in this condition endogenous subclinical hyperthyroidism may exist for many years. The study was confined to females, because of sexual differences in bone metabolism and the predominance of women over men both in the prevalence of multinodular goitre and in the clinical consequenses of bone loss. The existence of nodularity in the thyroid was documented by $99 \mathrm{~m} \mathrm{Tc}$ scanning.

Biochemical determinations in serum of parameters of thyroid function and bone turnover were performed with commercially available assays; detection limits, intra- and interassay variations were determined in our own laboratory. The results of these determinations are presented in the following chapters. As osteocalcin appeared to be temperature sensitive (table 1) handling of blood samples was performed under cooled conditions.

\section{Table 1}

Osteocalcin values in 2 healthy volunteers under different temperature conditions.

\begin{tabular}{|c|c|c|c|c|}
\hline $\begin{array}{l}A \text { and } B \\
A^{\prime} \text { and } B^{\prime}\end{array}$ & \multicolumn{4}{|c|}{$\begin{array}{l}\text { : aliquots between determinations stored } \\
\text { in a refrigerator at }-20^{\circ} \mathrm{C} \text {. } \\
\text { : aliquots between determinations stored } \\
\text { at room temperature. }\end{array}$} \\
\hline \multirow[t]{2}{*}{ TIME } & \multicolumn{4}{|c|}{ OSTEOCALCIN $(\mu \mathrm{g} / \mathrm{l})$} \\
\hline & A & $A^{\prime}$ & B & $B^{\prime}$ \\
\hline $30 \mathrm{~min}$. & 11 & 10.2 & 7.8 & 7.4 \\
\hline $60 \mathrm{~min}$. & 10.6 & 9.9 & 7.7 & 7.8 \\
\hline $120 \mathrm{~min}$ & 10.8 & 9.4 & 7.7 & 6.8 \\
\hline $180 \mathrm{~min}$ & 10.7 & 9.6 & 7.6 & 6.9 \\
\hline $360 \mathrm{~min}$. & 10.3 & 8.7 & 7.4 & 6.1 \\
\hline
\end{tabular}

In Chapter 2 the value of a second generation TSH assay is explored as a first line thyroid function test in a population with suspected hyperthyroidism.

In Chapter 3 the variation with age and body mass of serum osteocalcin and bone density in 125 healthy females is described. Interdependent correlations between these parameters and thyroid function parameters were explored by multiple regression analysis. Bone density was measured in the forearm by single photon absorptiometry (SPA). This method has been approved by the combined American and European Consensus Development Conference as a 
reliable method for the measurement of bone density with a good predictive value for subsequent fractures of all types (Conference Report, 1991).

In Chapter 4 a cross-sectional study is described of age corrected values of forearm bone density in 23 women with untreated multinodular goitre and subclinical hyperthyroidism compared with data obtained in 54 euthyroid women with multinodular goitres.

In Chapter 5 the results of determinations of osteocalcin, corrected for age, and of alkaline phosphatase in these subjects are described.

In Chapter 6 data of PEP/LVET ratios and heart rates are described in women with subclinical hyperthyroid multinodular goitres in comparison with women with euthyroid multinodular goitres.

In Chapter 7 some data are presented regarding bone metabolism and forearm bone density in a longitudinal follow-up of 8 subclinical hyperthyroid women during thyrostatic treatment in comparison with 8 untreated women with the same condition.

In Chapter 8 the studies described in this thesis are discussed.

In Chapter 9 all studies are summarized.

References of this Chapter are listed in Chapter 8. 


\section{Chapter 2}

\section{TSH-IRMA AS FIRST-LINE THYROID FUNCTION TEST IN SUSPECTED HYPERTHYROIDISM}

A.H. Mudde, A.J. Bastiaanse, H. Jonkers

Published (in Dutch) in: Ned Tijdschr Geneeskd, 1987; 131: 2364-2368. Original title: TSH-IRMA als eerste diagnosticum bij vermoeden van hyperthyreoïdie. 
The value of the very sensitive immuno-radiometric assay for TSH (TSH-IRMA) as first-line thyroid function test was evaluated in 36 patients with suspected hyperthyroidism. On the basis of elevated serum thyroxine concentration and subnormal response of TSH to 200 micrograms intravenous TRH, as measured by radio-immuno assay (TSH-RIA), 14 patients were classified as having hyperthyroidism. The basal TSH-IRMA concentration appears reliably to predict the response of TSH to TRH. Moreover, discrimination between normal basal TSH levels in euthyroidism and subnormal TSH levels in hyperthyroidism is possible with this IRMA.

TSH-IRMA can serve as a satisfying first-line test for suspected hyperthyroidism. The diagnosis of hyperthyroidism is very unlikely in case of a normal value. A subnormal value indicates autonomous thyroid function. In that case determination of thyroid hormone concentration may confirm the diagnosis of hyperthyroidism. 
In the past years several new thyroid function tests have become available. The disadvantages of the free thyroxine index (FTI), as deducted from the total serum thyroxine (T4) concentration and the triiodothyronine-resine-uptake, have induced the development of new tests for the determination of serum free T4 (FT4) concentrations. Except for the rare case of thyroid stimulating hormone (TSH)-producing pituitary tumors, hyperthyroidism is characterized by suppression of TSH release. The usual radio-immuno assays for determination of TSH (TSH-RIA's), however, are not sensitive enough to distinguish between euthyroidism and hyperthyroidism. In contrast, discrimination between eu- and hyperthyroidism may be possible with the recently developed immunoradiometric assays for TSH (TSH-IRMA's) (1).

We investigated the value of the TSH-IRMA in the first-line evaluation of suspected hyperthyroidism in a setting of an out-patient Clinic.

\section{SUBJECTS AND METHODS}

During a 5 months period all subjects refered to the out-patient Clinic were tested for FTI, FT4, thyrotropin releasing hormone (TRH)-test and TSH-IRMA. Serum was stored at a temperature of $-20^{\circ} \mathrm{C}$ for determination of $\mathrm{T} 3$ when the initial determinations gave incompatible results.

The total number of subjects was 36 ( 28 females and 8 males), aging between $16-83$ years (mean 51 years). Eleven subjects were using drugs ( $\beta$-blockers, $n$ $=4$; oral contraceptives, $n=3$; digoxine, $n=3$; tetracyclic antidepressive medication, $\mathrm{n}=2$; disopyramide, $\mathrm{n}=1$; isosorbide-dinitrate, $\mathrm{n}=1$; a diuretic, $\mathrm{n}$ $=1$; hydralazine, $\mathrm{n}=1$; ranitidine, $\mathrm{n}=1$; acenocumarol, $\mathrm{n}=1$; domperidone, $\mathrm{n}$ $=1$ and insulin, $n=1) . A^{99 m}$ Tc-thyroid scan was performed in all subjects with suspected (multi)nodular goitre, De Quervain's subacute thyroiditis, or thyrotoxicosis without goitre or exophthalmus. Antibodies against thyroid microsomes and against colloid were determined according to clinical indications (absense of goitre or diffuse goitre, with or without exophthalmus). Following this protocol a "classifying" diagnosis of thyroid disease was made in 22 subjects: multinodular goitre in 12, auto-immune thyroiditis in 6 , De Quervain's subacute thyroiditis in 2, solitary autonomous thyroid nodule in 1 and goitre related to puberty in 1 .

Fasting blood samples were taken between 8.00 and 9.00 a.m.. After centrifugation aliquots of serum were frozen at $-20^{\circ} \mathrm{C}$. Serum concentrations of total-T4 were determined by a double antibody-RIA. FTI was calculated from 
total T4 x T3-resine-uptake. The FTI-reference interval ( $95 \% \pm 2 \mathrm{SD})$, determined in our own laboratory in 100 healthy adults, was: $14.7-52.4$. FT4 was determined by the "SPAC-FT4-fraction test" (Mallinckrodt Diagnostica, reference values according to the manufacturer $7.7-23.2 \mathrm{pmol} / \mathrm{l})$. TSH-RIA was determined by a double-antibody-RIA-method (Diagnostic Products Corporation); clinical lower limit: $1.0 \mathrm{mU} /$. TRH testing was performed by intravenous injection of $200 \mu \mathrm{g}$ TRH (Roche). Serum concentrations of basal TSH and values 20 minutes after injection of TRH were determined by RIA. The TSH response to TRH was considered subnormal when the increase of TSH was less than $1 \mathrm{mU} / \mathrm{l}(\Delta \mathrm{TSH}-\mathrm{RIA}<1 \mathrm{mU} / \mathrm{l})$ and normal at values of $\Delta \mathrm{TSH} \geq 1 \mathrm{mU} / \mathrm{l}$ (1).

TSH-IRMA determinations were performed with a commercialy available immuno-radiometric assay against human TSH (CIS, France). An analytical evaluation of this assay has recently been described (2). Although we determined the detection limit of this assay at $0.07 \mathrm{mU} / 1$ (concentration 0 standard + $2 \mathrm{SD}$ ), we used a cut-off value of $0.1 \mathrm{mU} / \mathrm{l}$ to avoid overlap between the clinical lower limit and the detection limit of the assay. The intra-assay-variations at TSH concentrations of $0.8,2.1$ and $7.4 \mathrm{mU} / 1$ were $7.3 \%, 3.9 \%$ and $2.9 \%$, respectively $(\mathbf{n}=10)$. The inter-assay-variations at TSH concentrations of 0.4 , 2.2 and $10.5 \mathrm{mU} / \mathrm{h}$ were $8.0 \%, 6.5 \%$ and $6.1 \%$, respectively $(\mathrm{n}=29)$.

The diagnosis of hyperthyroidism was confirmed according to the following criteria: (a) subnormal response of TSH to injection of TRH and (b) FTI > 52.4 and/or FT4 $>23.2 \mathrm{pmol} / \mathrm{l}$. The diagnosis of hyperthyroidism was rejected when the response of TSH to TRH was normal, or when at a subnormal response of TSH to TRH both FTI and the serum concentration of FT4 were normal. In the last situation the serum concentration of total $\mathrm{T} 3$ was determined. Because in no case this resulted in a diagnosis of "T3-thyrotoxicosis", T3-data are not further considered here. Note that in this strategy the determination of TSH by IRMA was not used as a criterium for the diagnosis of hyperthyroidism.

According to Bayes theorema the following definitions were made (3):

\begin{tabular}{lllll}
\hline & FTI & $\begin{array}{l}\text { FT4 } \\
(\mathrm{pmol} / \mathrm{l})\end{array}$ & $\begin{array}{l}\text { TSH-RIA } \\
(\mathrm{mU} / \mathrm{l})\end{array}$ & $\begin{array}{l}\text { TSH-IRMA } \\
(\mathrm{mU} / \mathrm{l})\end{array}$ \\
\hline positive test result & $>52.4$ & $>23.2$ & $<1.0$ & $<0.1$ \\
negative test result & $\leq 52.4$ & $\leq 23.2$ & $\geq 1.0$ & $\geq 0.1$ \\
\hline
\end{tabular}

The total number of subjects with positive, respectively negative test results $=\mathrm{S}+$, respectively $\mathrm{S}-$. The total number of subjects with subnormal, respective- 
ly normal responses of TSH to TRH $=\mathrm{T}+$, respectively $\mathrm{T}-$. The total number of subjects with, respectively without hyperthyroidism $=\mathrm{H}+$, respectively $\mathrm{H}$ -

The sensitivity (Se) of the different tests for the outcome of the TRH-test was defined as the probability $(\mathrm{P})$ of a positive test result when there was a subnormal response of TSH to TRH. In formula: $\mathrm{Se}=\mathrm{P}(\mathrm{S}+\mathrm{IT}+)$. The specificity $(\mathrm{Sp})$ of the different tests for the outcome of the TRH-test was defined as the probability of a negative test result when there was a normal response of TSH to TRH: $\mathrm{Sp}=\mathrm{P}(\mathrm{S}-\mathrm{TT}-)$. Likewise, related to the diagnosis of hyperthyroidism, sensitivity and specificity were defined as: $\mathrm{Se}=\mathrm{P}(\mathrm{S}+\mathrm{IH}+)$ and $\mathrm{Sp}=\mathrm{P}(\mathrm{S}-\mathrm{IH}-)$, respectively. Taking into account the prevalences $(\mathrm{Pr})$ of subjects with subnormal responses of TSH to TRH, respectively existence of hyperthyroidism in the study group $(\mathrm{Pr}=\mathrm{T}+$, resp. $\mathrm{H}+\mathrm{l}$ total number of subjects $)$, the positive predictive value $(\mathrm{PV}+)$ of a test result was defined as:

$$
\frac{S e \times P r}{S e \times P r+(1-S p)(1-P r)}
$$

The negative predictive value (PV-) was defined as:

$$
\frac{S p(1-P r)}{S p \times(1-P r)+(1-S e) P r} \text {. }
$$

The relation between $\triangle$ TSH-RIA and basal TSH-IRMA was calculated by linear regression analysis, not considering values below the lower limits of the assays.

\section{RESULTS}

\section{TRH test}

Seventeen subjects had a subnormal response of TSH to TRH (Pr $=0.47$ ). Sixteen of them had serum concentrations of TSH-IRMA $<0.1 \mathrm{mU} /$, which implies a sensitivity of TSH-IRMA for the TRH-test of 0.94 .

All of the remaining 19 subjects with a normal response of TSH on TRH had serum concentrations of TSH-IRMA $\geq 0.1 \mathrm{mU} / \mathrm{l}(\mathrm{Sp}=1)$ (table 1). There appeared to be a good linear correlation between TSH-IRMA and TSH-RIA ( $y$ $=0.13 x+0.13 ; r=0.897 ; P<0.001$; (fig. 1$)$ ). As a consequence of the high sensitivity and specificity of the TSH-IRMA this assay had higher positive and negative predictive values than the other tests (table 2). 
Table 1

Determinations in serum of the free-thyroxine-index (FTI), free thyroxine (FT4) concentration and TSH concentration measured by radio-immunoassay (TSH-RIA) and immunoradiometricassay (TSH-IRMA) in 36 subjects suspected for hyper-thyroidism.

\begin{tabular}{|c|c|c|c|c|c|c|c|}
\hline Subject & sex & $\begin{array}{l}\text { age } \\
\text { (years) }\end{array}$ & diagn.* & FTI & $\begin{array}{r}\text { FT4 } \\
(\mathrm{pmol} / \mathrm{l})\end{array}$ & $\begin{array}{r}\text { TSH-IRMA } \\
(\mathrm{mU} / \mathrm{l})\end{array}$ & $\begin{array}{r}\text { TSH-RIA } \\
(\mathrm{mU} / \mathrm{l})\end{array}$ \\
\hline
\end{tabular}

Subnormal response of TSH to TRH ( $\triangle T S H-R I A<1.0 \mathrm{mUll})$

$\begin{array}{lllllllr}\text { A } & \text { m } & 61 & \text { AN } & 49 & 30.2 & <0.1 & <1.0 \\ \text { B } & \text { f } & 41 & \text { MG } & 80 & 31.4 & <0.1 & 1.2 \\ \text { C } & \text { f } & 58 & \text { MG } & 42 & 23.9 & <0.1 & <1.0 \\ \text { D } & \text { m } & 34 & \text { AI } & 51 & 24.1 & <0.1 & <1.0 \\ \text { E } & \text { f } & 52 & \text { AI } & 102 & 68.5 & <0.1 & 1.0 \\ \text { F } & \text { m } & 34 & \text { AI } & 87 & 54.4 & <0.1 & <1.0 \\ \text { G } & \text { f } & 52 & \text { MG } & 60 & 25.6 & <0.1 & 1.1 \\ \text { H } & \text { f } & 78 & \text { MG } & 77 & 40.5 & <0.1 & 1.3 \\ \text { J } & \text { f } & 42 & \text { QUE } & 58 & 28.2 & <0.1 & <1.0 \\ \text { K } & \text { m } & 40 & \text { AI } & 93 & 45.8 & <0.1 & <1.0 \\ \text { L } & \text { m } & 68 & \text { MG } & 44 & 26.2 & <0.1 & <1.0 \\ \text { M } & \text { f } & 41 & \text { MG } & 27 & 12.4 & 0.25 & <1.0 \\ \text { N } & \text { f } & 65 & \text { MG } & 52 & 28.9 & <0.1 & 1.0 \\ \text { O } & \text { f } & 43 & \text { QUE } & 44 & 21.4 & <0.1 & <1.0 \\ \text { P } & \text { f } & 66 & \text { MG } & 55 & 26.9 & <0.1 & <1.0 \\ \text { Q } & \text { f } & 54 & \text { MG } & 37 & 19.9 & <0.1 & 1.0 \\ \text { R } & \text { f } & 16 & \text { AI } & 136 & 74.6 & <0.1 & <1.0\end{array}$

Normal response of TSH to TRH ( $\triangle T S H-R I A \geq 1.0 \mathrm{mUll}$ )

\begin{tabular}{lllllllr} 
S & f & 79 & MG & 28 & 15.2 & 2.0 & 3.4 \\
T & m & 39 & NT & 26 & 12.5 & 1.8 & 2.8 \\
U & f & 49 & MG & 28 & 13.9 & 4.4 & 6.8 \\
V & f & 24 & NT & 42 & 17.9 & 3.5 & 3.6 \\
W & f & 65 & MG & 54 & 22.5 & 0.9 & 1.5 \\
X & f & 20 & NT & 34 & 15.2 & 2.1 & 2.5 \\
Y & f & 50 & NT & 25 & 12.7 & 0.6 & $<1.0$ \\
Z & f & 65 & NT & 41 & 18.6 & 0.7 & 1.7 \\
AA & f & 71 & NT & 42 & 17.0 & 1.3 & 1.8 \\
BB & f & 17 & PUB & 42 & 16.1 & 1.6 & 2.5 \\
CC & f & 76 & NT & 42 & 20.8 & 1.8 & 3.0 \\
DD & f & 83 & NT & 52 & 25.1 & 0.4 & 1.3 \\
EE & f & 22 & NT & 21 & 9.4 & 2.0 & 2.3 \\
FF & f & 69 & NT & 43 & 19.2 & 1.0 & 1.8 \\
GG & f & 43 & NT & 36 & 15.2 & 1.0 & 1.6 \\
HH & f & 63 & NT & 45 & 20.6 & 2.1 & 3.4 \\
JJ & m & 68 & NT & 32 & 16.2 & 1.0 & 1.4 \\
KK & m & 62 & NT & 33 & 16.7 & 0.2 & 1.1 \\
LL & f & 27 & AI & 25 & 10.8 & 0.8 & 6.8 \\
\hline
\end{tabular}

* Abbreviations: $\mathrm{AN}=$ autonomic nodule, $\mathrm{MG}=$ multinodular goitre, $\mathrm{AI}=$ auto-immune- 


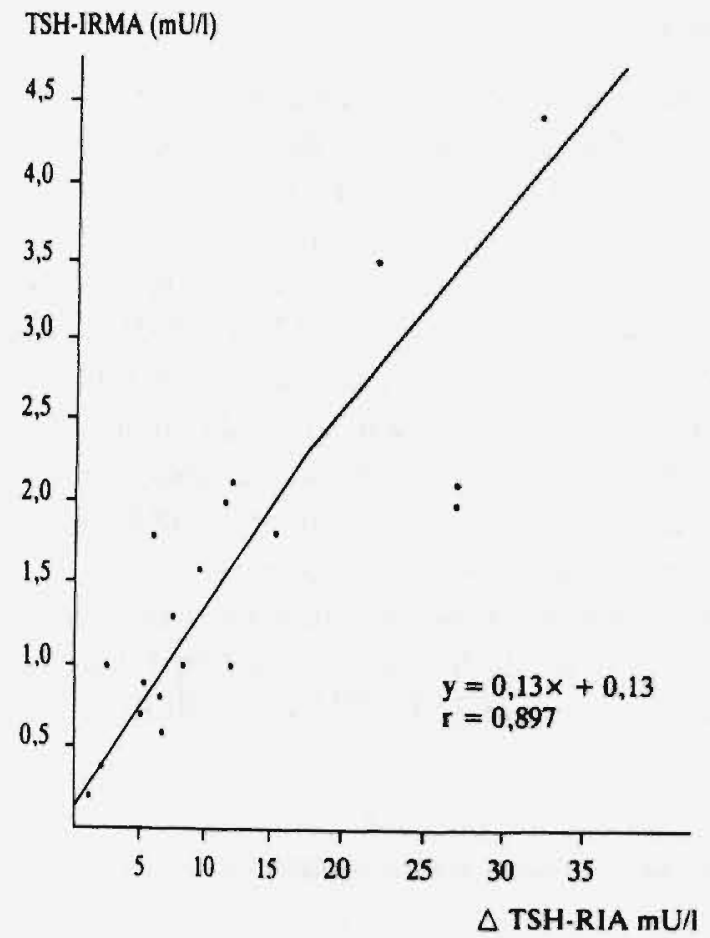

\section{Figure 1}

Relation between the basal serum concentration of TSH-IRMA and the TSH-RLA response to $200 \mu \mathrm{g}$ TRH intravaneously ( $\triangle$ TSH-RIA)

\section{Table 2}

Predictive values of different hormonal analyses related to the thyrotropin releasing hormone (TRH)-test.

\begin{tabular}{lllll}
\hline & FTI & FT4 & TSH-IRMA & TSH-RIA \\
\hline Sensitivity & 0.53 & 0.82 & 0.94 & 0.65 \\
Specificity & 0.95 & 0.95 & 1 & 0.95 \\
Positive predictive value & 0.89 & 0.94 & 1 & 0.92 \\
Negative predictive value & 0.69 & 0.86 & 0.95 & 0.75 \\
\hline
\end{tabular}




\section{Hyperthyroidism}

Following the above defined criteria 14 subjects were considered thyrotoxic $(\mathrm{Pr}$ $=0.39$ ). In the 11 subjects using drugs there were no discrepancies between the different test results. These subjects are not considered separately in the presented data. In all hyperthyroid subjects serum concentrations of TSHIRMA were $<0.1 \mathrm{mU} / 1$. In two subjects showing a basal TSH-IRMA $<0.1 \mathrm{mU} / 1$ combined with a subnormal response of TSH to TRH, the diagnosis of hyperthyroidism was rejected because of normal values of both FTI and of FT4. One of these had De Quervain's subacute thyroiditis (subject 0 ), the other had a multinodular goitre (subject Q). In the former subject a serum determination of FTI, performed in the same laboratory on request of the primary physician, had revealed an elevated value (64) 3 weeks before.

In none of the subjects showing serum concentrations of TSH-IRMA $\geq 0.1$ $\mathrm{mU} / \mathrm{l}$ a diagnosis of hyperthyroidism was confirmed. The positive, respectively negative predictive values of TSH-IRMA and TSH-RIA are depicted in table 3.

\section{Table 3}

Predictive values of different thyroid stimulating hormone(TSH)-assays related to the diagnosis of hyperthyroidism.

\begin{tabular}{lll}
\hline & TSH-IRMA & TSH-RIA \\
\hline Sensitivity & 1 & 0.64 \\
Specificity & 0.91 & 0.86 \\
Positive predictive value & 0.88 & 0.74 \\
Negative predictive value & 1 & 0.63 \\
\hline
\end{tabular}

\section{DISCUSSION}

Several groups of investigators have assigned a central role to the TSH-IRMA in the strategy of thyroid function testing $(1,4,5)$. It should be noted, however, that the results of the different studies, including this one, are related to the composition of the patient groups and to the cut-off values of the different tests. In this study the prevalence of hyperthyroidism was high, because the subjects were selected for clinical suspicion of hyperthyroidism. The predictive values of the different tests are dependent on the prevalence of disease. Sensitivity and specificity are highly determined by the cut-off values of the different tests. In this study the variation coefficients of the different assays were not considered 
in the calculations. Recently Klee and Hay have stressed the importance of differentiating between the detection limit of the assay and the lower limit of normal values in the evaluation of different TSH-assays (6). For this reason we defined the cut-off value of TSH-IRMA at $0.1 \mathrm{mU} / \mathrm{l}$ while the detection limit of the assay was $0.07 \mathrm{mU} / \mathrm{l}$.

Comparison of both TSH-assays reveals that, in contrast to the RIA method, the TSH-IRMA gives reliable results in the low range, resulting in a much better positive predictive value for the outcome of the TRH test. Moreover, there was a significant correlation between basal TSH-IRMA and the response of TSH to TRH measured by RIA (fig. 1). This finding is in agreement with data emerging from other studies in which both basal and $\triangle \mathrm{TSH}$ have been determined by RIA or IRMA, respectively $(7,8)$.

The improved sensitivity of the TSH-IRMA in comparison to the TSH-RIA is also advantageous in the diagnosis of hyperthyroidism. In our study population no case of hyperthyroidism was found at TSH levels $\geq 0.1 \mathrm{mU} / \mathrm{l}$. It thus appears suitable to reject a diagnosis of primary hyperthyroidism on a basal TSH value determined by this IRMA, which is not possible with the RIA method (PV-: 1 and 0.63, respectively). To confirm the diagnosis of hyperthyroidism, however, further diagnostic tests are needed. This is illustrated by the finding that a basal TSH value $<0.1 \mathrm{mU} / 1$ more reliably predicts a positive test outcome of a TRH-test $(\mathrm{PV}+=1)$ than the existence of hyperthyroidism $(\mathrm{PV}+=0.88)$. In other words a basal TSH $<0.1 \mathrm{mU} / \mathrm{l}$ is highly predictive for the existence of autonomic thyroid function, as in "subclinical hyperthyroidism" in the case of multinodular goitre (patient Q) and in the early recovering phase of hyperthyroidism in De Quervain's subacute thyroiditis (patient 0).

For further testing several thyroid hormone-assays are available. Comparison of FT4 with the FTI revealed that in the group of subjects showing a subnormal response of TSH to TRH the serum concentration of FT4 was elevated more often than the FTI (in 14 and 9 subjects, respectively). The diagnosis of hyperthyroidism thus was confirmed more often on the base of an elevated value of FT4 than of the FTI. While both FT4 and the FTI were included in the criteria for confirmation as well as for rejection of the diagnosis of hyperthyroidism, it is not possible to calculate predictive values of these determinations for the diagnosis of hyperthyroidism. However, the possibility that FT4 would be falsely elevated more often than FTI, is unlikely, while both tests gave only once false positive results (subjects DD and W, respectively) in the 19 subjects showing a normal response of TSH to TRH (indicating euthyroidism by definition). In daily clinical practice we prefer FT4 rather than FTI, because FT4 determinations are not influenced by variations in the serum concentrations 
of thyroxine-binding globulin and because of the satisfying experiences with this assay reported by others (9).

In conclusion we agree with others that the sensitive TSH-IRMA is an important acquisition in the diagnostic arsenal of hyperthyroidism (4-6). It is important that the lower limit of the normal range can be distinguished from the detection limit of the assay. For the TSH-assay used by us a discrimination value of $0.1 \mathrm{mU} / \mathrm{l}$ appears to be valid in clinical practice. When hyperthyroidism is suspected TSH-IRMA may be used as first-line test. At TSH-IRMA values $\geq$ $0.1 \mathrm{mU} / \mathrm{h}$ hyperthyroidism is very unlikely. Values of TSH-IRMA $<0.1 \mathrm{mU} / \mathrm{A}$ indicatie autonomic thyroid function. A supplemental thyroid hormone determination is required to confirm the diagnosis of hyperthyroidism. This strategy is shown in fig. 2.

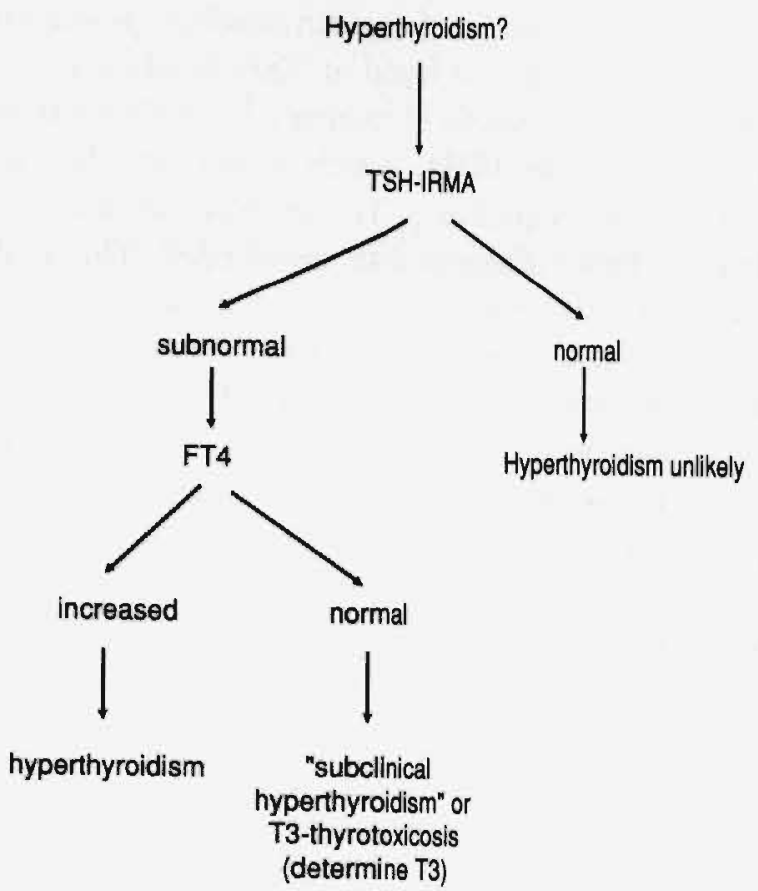

\section{Figure 2}

Diagram for the diagnostic work-up of hyperthyroidism. 


\section{REFERENCES}

1. Seth J, Kellett HA, Caldwell G, et al. A sensitive inmmunoradiometric assay for serum thyroid stimulating hormone: a replacement for the thyrotrophin releasing hormone-test? Br Med J 1984; 289: 1334-1336.

2. Kreutzer HJH, Tertoolen JFW, Thijssen JHH, Kinderen PJ der, Koppeschaar HPF. Analytical evaluation of four sensitive assays of thyrotropin, including effects of variations in patient sampling. Clin Chem 1986; 32: 2085-2090.

3. Balla JI, Tansek R, Elstein A. Bayesian diagnosis, in presence of pre-existing disease. Lancet 1985; i: 326-329.

4. Caldwell G, Gow SM, Sweeting VM, et al. A new strategy for thyroid function testing. Lancet 1985; i: 1117-1119.

5. Hopton MR, Harrop JS. Immunoradiometric assay of thyrotropin as a "first line" thyroid function test in the routine laboratory. Clin Chem 1986; 32: 691-693.

6. Klee GG, Hay ID. Assessment of sensitive thyrotropin assays for an expanded role in thyroid function testing: proposed criteria for analytic performance and clinical utility. $J$ Clin Endocrinol Metab 1987; 64: 461-471.

7. Wide L, Dahlberg PA. Quality requirements of basal S-TSH assays in predicting a S-TSH response to TRH. Scand J Clin Lab Invest 1980; 40(suppl 155): 101-110.

8. Seth J, Beckett G. Diagnosis of hyperthyroidism: the newer biochemical tests. J Clin Endocrinol Metab 1985; 14: 373-396.

9. Plebani M, Perobelli L, Burline A. A new method (SPAC ET) for free thyroxin in serum evaluated. Clin Chem 1986; 32: 680-683. 


\section{Chapter 3}

\section{RELATIONS BETWEEN OSTEOCALCIN, FOREARM BONE MINERAL DENSITY, THYROID FUNCTION, AGE AND BODY MASS IN HEALTHY WOMEN}

A.H. Mudde, FJ.L. Reijnders, H. Jonkers, A J. Bastiaanse, A.C. Nieuwenhuijzen Kruseman

Submitted for publication. 
In a cross-sectional study in 125 healthy females, aged between 21 and 75 years, the influence of age, body weight, body mass index and 2 seasons in relation to thyroid function on serum osteocalcin levels were analyzed. Moreover, body weight, body mass index and serum concentrations of osteocalcin and thyroid function parameters were analyzed in relation to forearm bone mineral density.

Serum concentrations of osteocalcin and thyroid function parameters were not different in the two periods of the year. The serum concentration of osteocalcin was independently correlated with age ${ }^{(1)}$ and body mass index ${ }^{(2)}$ (multiple $r=0.39, P^{(1)}<$ $0.0001, \mathrm{P}^{(2)}=0.013$ ). No correlations were found between osteocalcin and thyroid function parameters. Inverse correlations between osteocalcin and both distal and proximal forearm bone mineral density were determined by age-related variations in these variables. Forearm bone mineral density was not correlated with thyroid function parameters.

In conclusion the value of osteocalcin as a parameter of bone mineral density is questionable since the correlation between osteocalcin and forearm bone mineral density appears to be determined by age-related variations in both variables. Body mass index appears to be inversely correlated with bone turnover, but not with forearm bone mineral density. Variation in thyroid function within the normal range is neither correlated with bone turnover, nor with forearm bone mineral density. 
In healthy women parameters of bone turnover, like osteocalcin, and bone mineral density are determined by hormonal influences and by several other factors, like age, body composition and possibly seasonal variation (1 - 11). The influence of thyroid function on these parameters has recently attracted renewed attention because of possible adverse effects of mild thyroid hormone excess on bone metabolism $(12$ - 14). Information about the relations between serum osteocalcin concentration, bone mineral density and thyroid function in euthyroidism is nevertheless scanty. Analysis of these relations, however, is complicated, while thyroid function itself may be interrelated with age, body weight, body mass index and season $(15-17)$. For this reason we performed the present study in which we investigated these non-hormonal determinants of osteocalcin and forearm bone mineral density in relation to thyroid function in 125 healthy females. Moreover the value of osteocalcin as a parameter of bone mineral density was evaluated.

\section{MATERIAL AND METHODS}

One hundred and twenty five healthy women (median (range) age 42 (21 - 75) years) were recruted from the hospital staff and from patients attending the Internal or the Gynaecologic out-patient Clinic for minor medical problems, known to have no influence on bone density or thyroid function. There were 78 premenopausal (median (range) age $36(21-53)$ years) and 47 postmenopausal (median (range) age 59 (40-75) years) women. Informed consent was obtained from every subject and the study was approved by the hospital's ethical committee. Blood sampling was performed between 08.00 and 10.00 a.m. From each patient one sample was taken between April and September (summer period) and one sample between October and March (winter period). The mean $( \pm S D)$ interval between the two measurements was $6.8( \pm 2.1)$ months. Serum osteocalcin was determined by a radio-immuno assay using a rabbit antibovine osteocalcin antibody (CIS, France). The intra- and interassay coefficients of variation of this assay in the normal range were $1.7 \%$ and $6.3 \%$, respectively. Serum TSH was determined by an immuno-radiometric assay (CIS, France). The intra- and interassay coefficients of variation of this assay in the normal range were $3.9 \%$ and $6.5 \%$, respectively. Serum free T4 (FT4) was determined by the SPAC-FT4 fraction test (Byk-Sangtec Diagnostica, Germany). The intraand inter-assay coefficients of variation of this assay in the normal range were $6.7 \%$ and $7.4 \%$, respectively. Serum total T3 was determined by a double 
antibody radio-immuno assay (Euro/DPC, Great Britain). The intra- and interassay coefficients of variation of this assay in the normal range were $2.5 \%$ and $2.7 \%$ respectively. Bone mineral density (BMD) was measured in the nondominant forearm by single-photon absorptiometrie (Nuclear Data ND1100 A, U.S.A.). BMD-measurements were expressed in arbitrary units per square centimeter $\left(\mathrm{U} / \mathrm{cm}^{2}\right)$. The reproducibility of this method was assessed by 5 repeated measurements in 5 healthy volunteers within two weeks, resulting in coefficients of variation for the distal BMD and for the proximal BMD of $3.1 \%$ and $1.9 \%$, respectively.

Analysis of the data was performed using a statistical computer program (GB-stat, Dynamic Microsystems, Inc., U.S.A). Correlations were analyzed with repeated stepwise multiple linear regression analysis, in which the sequence of introduction of the variables in the equation was alternated, in order to detect interdependency of variables. To avoid entering variables that were highly interrelated, correlations with distal and proximal BMD and with body weight and body mass index were analyzed separately. Independent correlations between two variables were further described with the best fitting simple regression analysis. Differences between mean $( \pm S D$ ) or median (range) values were compared with the unpaired Students t test, or with the Mann Whitney's $\mathrm{U}$ test when appropriate. $\mathbf{P}<0.05$ was regarded as statistical significant.

\section{RESULTS}

\section{Descriptive data}

Body weight and body mass index were normaly distributed with mean ( \pm SD) values of $70.4 \pm 13.9 \mathrm{~kg}$ and $25.7 \pm 4.9\left(\mathrm{~kg} / \mathrm{m}^{2}\right)$, respectively. Serum osteocalcin and thyroid function parameters were not different in the two periods of the year during which the samples were collected (table 1). Therefore, the values of the samples taken in the period that the BMD measurements were done, were used for the further analyses.

\section{Correlates of osteocalcin}

In the stepwise multiple regression analysis osteocalcin appeared to be indepently correlated with age and body mass index, the significance of the correlation with age being much higher than with body mass index (osteocalcin $=9.774571+0.080023$ age $^{(1)}-0.12621$ body mass index ${ }^{(2)} ;$ multiple $\mathrm{r}=0.39$; $\left.\mathrm{P}^{(1)}<0.0001, \mathrm{P}^{(2)}=0.013\right)$. The relation of osteocalcin with age was further 
Table 1

Serum osteocalcin and thyroid function parameters in 125 healthy females in two seasons

\begin{tabular}{llll}
\hline variable & summer & winter & p-vatue \\
\hline osteocalcin $(\mathrm{ug} / \mathrm{l})$ & $9.7 \pm 2.9$ & $10.3 \pm 2.6$ & 0.15 \\
TSH $(\mathrm{mU} / \mathrm{l})$ & $1.45(0.1-3.9)$ & $1.35(0.27-4.9)$ & 0.28 \\
FT4 (pmol/h) & $12.2 \pm 2.1$ & $12.6 \pm 1.9$ & 0.87 \\
Total T3 $(\mathrm{nmol} /)^{2}$ & $2.1 \pm 0.4$ & $2.0 \pm 0.4$ & 0.29 \\
\hline
\end{tabular}

values as mean ( $\pm S D$ ) or median (range); ${ }^{a} n=67$

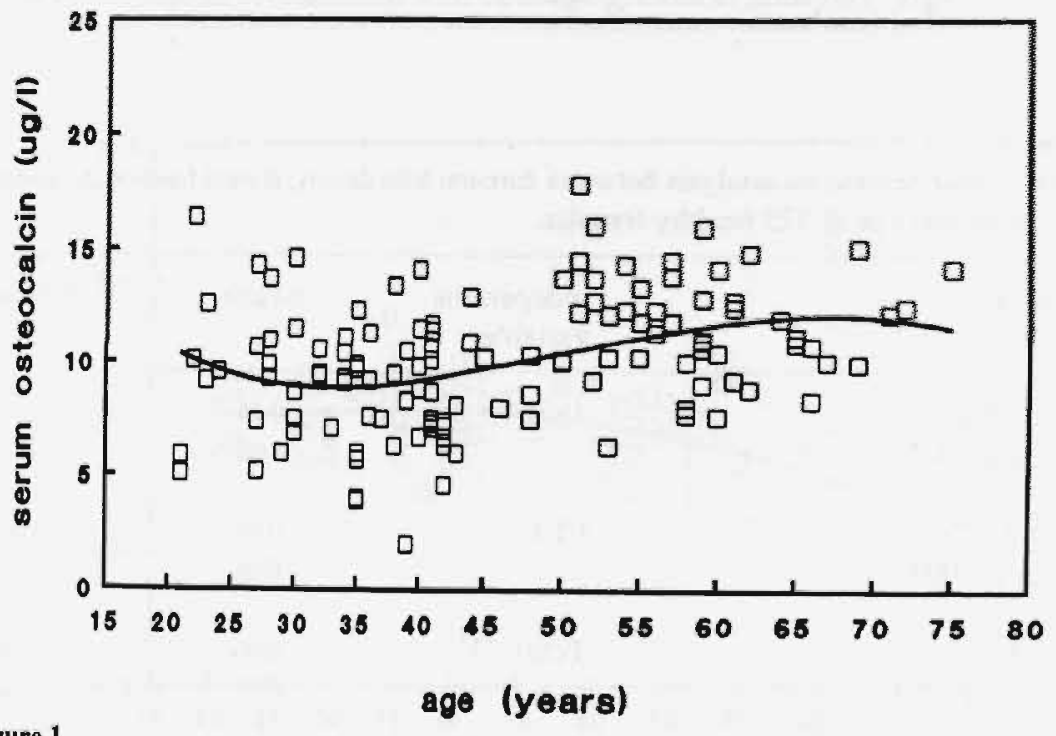

Figure 1

Relation between serum osteocalcin and age in 125 healthy females. $(y=23.86536-1.080274 x$ $+0.024269 x^{2}-0.000161 x^{3} ; r=0.39 ; P=0.0002$ ).

substantiated with cubic regression analysis (fig 1). Univariate analysis did not show any significant correlations between either osteocalcin and weight $(\mathrm{r}=$ $0.15 ; \mathrm{P}=0.09)$ or between osteocalcin and TSH $(\mathrm{r}=-0.03 ; \mathrm{P}=0.74)$, osteocalcin and FT4 $(r=0.14 ; P=0.13)$ or osteocalcin and total T3 $(r=0.10 ; P$ $=0.31$ ). When distal and proximal BMD respectively where introduced as first step in the multiple regression equation osteocalcin revealed inverse correlations with both of these variables $(\mathrm{r}=-0.23 ; \mathrm{P}=0.0093$ and $\mathrm{r}=-0.27 ; \mathrm{P}=$ 
Table 2

Multiple regression analysis between serum osteocalcin as dependent variable and forearm bone density, body mass index and age as independent variables in 125 healthy females.

\begin{tabular}{llll}
\hline $\begin{array}{l}\text { Dependent } \\
\text { variable }\end{array}$ & $\begin{array}{l}\text { Independent } \\
\text { variable }\end{array}$ & $\begin{array}{l}\text { multiple } \\
\text { r-value }\end{array}$ & P-value \\
\hline & $\begin{array}{l}\text { distal BMD } \\
\text { body mass index } \\
\text { osteocalcin }\end{array}$ & 0.40 & $\begin{array}{l}0.37 \\
\text { age }\end{array}$ \\
osteocalcin & $\begin{array}{l}\text { proximal BMD } \\
\text { body mass index } \\
\text { age }\end{array}$ & 0.0131 \\
& & 0.0011 \\
& & & 0.22 \\
& & 0.0146 \\
\hline
\end{tabular}

Table 3

Simple linear regression analysis between forearm bone density, thyroid function parameters, body mass and age in 125 healthy females.

\begin{tabular}{llll}
\hline $\begin{array}{l}\text { Dependent } \\
\text { variable }\end{array}$ & $\begin{array}{l}\text { Independent } \\
\text { variable }\end{array}$ & r-value & P-value \\
\hline $\begin{array}{llll}\text { distal BMD } \\
\text { proximal BMD }\end{array}$ & TSH & 0.15 & 0.09 \\
distal BMD & & 0.18 & 0.04 \\
proximal BMD & FT4 & -0.04 & 0.65 \\
distal BMD & & -0.08 & 0.38 \\
proximal BMD & Total T3 & \\
distal BMD & & -0.06 & 0.56 \\
proximal BD & body weight & 0.01 & 0.92 \\
$\begin{array}{l}\text { distal BMD } \\
\text { proximal BMD }\end{array}$ & & 0.07 & 0.42 \\
distal BMD & body mass index & -0.08 & 0.49 \\
proximal BMD & & -0.05 & 0.38 \\
\hline a $=67$ & age & -0.50 & 0.55 \\
\hline
\end{tabular}


0.0022 , respectively). The significance of these correlations, however, was lost when age was introduced as next step in the regression equation (table 2).

\section{Correlates of bone mineral denstiy}

Stepwise multiple regression analysis revealed a tendency to a correlation between distal BMD and TSH and a weak correlation between proximal BMD and TSH, when these parameters were introduced as first step in the equation (table 3). The significance of this correlation, however, was lost when age was introduced as next step in the equation. None of the other variables was correlated with forearm BMD (table 3). The correlation between forearm BMD and age was further substantiated with cubic regression analysis (figs. 2 and 3 ).

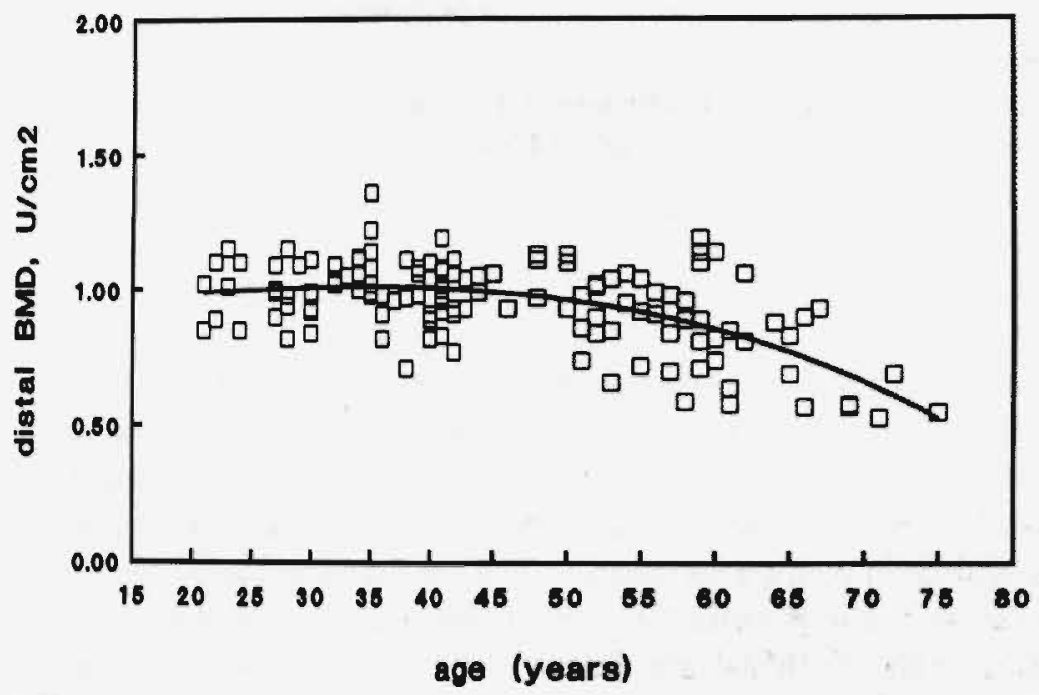

Figure 2

Relation between distal BMD and age in 125 healthy females. $(y=0.974144-0.002408 x+$ $\left.0.000227 x^{2}-0.000004^{* 3} ; r=0.59 ; P<0.0001\right)$. 


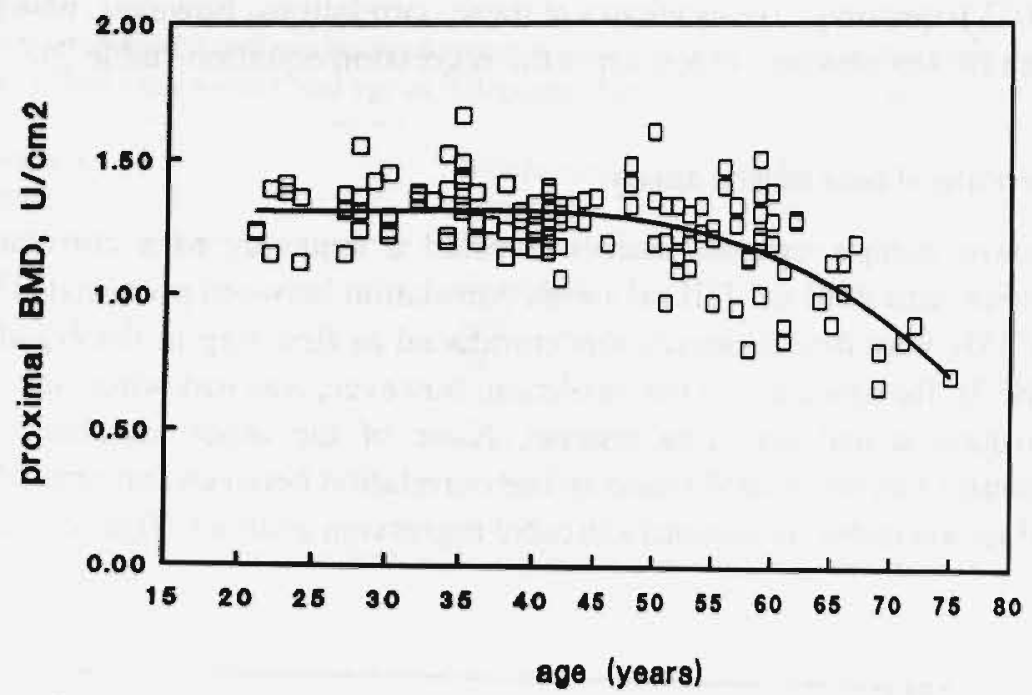

\section{Figure 3}

Relation between proximal BMD and age in 125 healthy females. $(y=1.506425-0.020131 x$ $\left.+0.000674 x^{2}-0.000007 x^{3} ; r=0.65 ; P<0.0001\right)$.

\section{DISCUSSION}

A seasonal variation in serum osteocalcin levels has recently been described (8), but this observation is not supported by the present and other studies $(9,18)$. Although absolute values in serum osteocalcin in relation to age have differed widely between various studies, most of the data have indicated that serum osteocalcin in women increases around the menopausal age (2 - 6). The present data show a slight decline in serum osteocalcin in early adult life, reaching a nadir in the fourth decade, followed by an increase around the age of fifty, which tends to reach a plateau phase in the following decades. The relative contribution of menopause to this age-related variation in osteocalcin cannot be assessed in this cross-sectional study, while age and years since menopause are closely interrelated.

Osteocalcin is produced by osteoblasts $(19,20)$. The most important impulse for osteocalcin production is 1,25 -dihydroxyvitamin $\mathrm{D} 3$, as was shown both in vitro and in vivo $(19,21,22)$. In osteoblastlike osteosarcoma-cells in rats, however, a direct effect of T3 on osteocalcin release has been documented (23). Conflicting data are reported on the correlation between serum osteocalcin and thyroid function parameters in thyroid disease. Garrel et al. (24) have reported a positive correlation between serum osteocalcin and serum $\mathrm{T} 3$ in subjects with 
hyperthyroidism. In contrast, other studies, both in overt thyroid hormone excess and in euthyroid and subclinical thyrotoxic goitre have not established a correlation between serum concentrations of osteocalcin and thyroid hormones $(4,25,26)$. An inverse correlation between osteocalcin and TSH, however, has been reported in goitre disease and in subjects taking L-thyroxine medication $(14,26)$. Comparison of these data, is difficult because of differences in study populations and selection criteria. In the present study we could not establish a correlation between serum osteocalcin and any of the thyroid function parameters in 125 euthyroid healthy females. Assuming that osteocalcin is a sensitive marker of bone turnover this implies that there is no indication that bone turnover is influenced by the level of thyroid function within the euthyroid range.

Several investigators have studied osteocalcin in relation to $\operatorname{BMD}(3,25,27$ -29). Johansen et al. (28) have shown that the actual serum osteocalcin level is correlated with future loss of bone. In hyperthyroidism serum osteocalcin has been reported to correlate negatively with the Z-score of spinal BMD (25). Several studies, however, have indicated that biochemical parameters, including osteocalcin, have a poor predictive value for the actual BMD $(3,28,29)$. Our data are in agreement with this opinion, showing that the correlation between osteocalcin and BMD in healthy females is determined by age-related changes in both parameters. The age-related distribution of forearm BMD in the present study shows a pattern similar to previously reported Dutch studies using the same method, although the absolute levels may be slightly different $(30,31)$.

Forearm BMD is reported to correlate inversely with both body weight (32) and body mass index (33). Recent studies, however, have indicated that body fat is a more stronger determinant of BMD than these variables $(10,11)$. In our study population neither body weight nor body mass index was correlated with forearm BMD. In contrast, body mass index appeared to be inversely correlated with bone turnover reflected by the serum osteocalcin level. This is in agreement with data of Ribot et al. (33) showing a negative influence of obesity on postmenopausal osteocalcin levels. The absence of a correlation between body mass index and BMD, despite the inverse correlation between body mass index and osteocalcin, may be declared by the non-weight bearing function of the forearm.

Thyroid hormone excess may result in decreased bone density as was shown both in overt and in subclinical thyrotoxicosis $(12,13,25)$. Our present data show that there is no independent correlation between forearm BMD and thyroid function parameters in euthyroid healthy females, although a tendency to lower BMD with lower serum TSH levels was observed. 
In summary in our study of 125 healthy females serum osteocalcin concentration was highly correlated with age, showing a decline in adult life, reaching a nadir in the fourth decade and than increasing around the menopausal age to reach a postmenopausal plateau phase. Since the correlation between osteocalcin and forearm BMD is determined by age-related variatons in both variables the value of osteocalcin as a parameter of BMD is questionable. Body mass index was independently inversely correlated with bone turnover, reflected by the serum osteocalcin concentration, but not with forearm BMD. We were unable to show any influence of variation in thyroid function within the normal range on either bone turnover or forearm BMD. 
1. Price PA, Parthemore JG, Deftos LJ. New biochemical marker fore bone metabolism. Measurements by radioimmunoassay of bone Gla-protein in the plasma of normal subjects and patients with bone disease. J Clin Invest 1980; 66: 878- 883.

2. Delmas PD, Stenner D, Wahner HW, Mann KG, Riggs BL. Increase in serum bone y-carboxyglutamic acid protein with aging in women. J Clin Invest 1983; 71: 1316-1321.

3. Epstein S, McClintock R, Bryce G, Poser J, Johnston jr CC, Hui S. Differences in serum bone Gla-protein with age and sex. Lancet 1984; I: $307-310$.

4. Duda jr RJ, O'Brien JF, Katzmann JA, Peterson JM, Mann KG, Riggs BL. Concurrent assays of circulating bone Gla-protein and bone alkaline phosphatase: effects of sex, age and metabolic bone disease. J Clin Endocrinol Metab 1988; 66: 955 - 957.

5. Worsfold M, Sharp ChrA, Davie MWJ. Serum osteocalcin and other indices of bone formation: An 8-decade population study in healthy men and women. Clin Chim Act 1988; 178: $225-236$.

6. Tarallo P, Henny J, Fournier B, Siest G. Plasma osteocalcin: Biological variations and reference limits. Scand J Clin Lab Invest 1990; 50: 649 - 655.

7. Nielsen HK, Brixen K, Mosekilde L. Diumal rhythm and 24-hour integrated concentrations of serum osteocalcin in normals: influence of age, sex, season and smoking habits. Calcif Tissue Int 1990; 47: 284-290

8. Nordin BE, Need AG, Chatterton BE, Horowitz M, Morris HA. The relative contributions of age and years since menopause to postmenopausal bone loss. J Clin Endocrinol Metabol 1990; 70: 83 - 88 .

9. Vanderschueren D, Gevers G, Dequeker J, et al. Seasonal variation in bone metabolism in young healthy subjects. Calcif Tissue Int 1991; 49: 84-89

10. Reid IR, Ames R, Evans MC, et al. Determinants of total body and regional bone mineral density in normal postmenopausal women - a key role for fat mass. J Clin Endocrinol Metab 1992; 75: 45 - 51 .

11. Compston JE, Bhambhami M, Laskey MA, Murphy S, Khaw KT. Body composition and bone mass in post-menopausal women. Clin Endocrinol 1992; 37: 426 - 431.

12. Ross DS, Neer RM, Ridgway EC, Daniels GH. Subclinical hyperthyroidism and reduced bone density as a possible result of prolonged suppression of the pituitary thyroid axis with L-thyroxine. Am J Med 1987; 82: 1167 - 1172.

13. Mudde AH, Reijnders FJ, Nieuwenhuijzen Kruseman AC. Peripheral bone density in women with untreated multinodular goitre. Clin Endocrinol 1992; 37: 35 - 39.

14. Faber J, Perrild H, Johansen JS. Bone Gla protein and sex hormone-binding globulin in nontoxic goiter: parameters for metabolic status at the tissue level. $J$ Clin Endocrinol Metab 1990; 70: 49 - 55 .

15. Hermann J, Rusche HJ, Kroll HJ, et al. Free triiodothy (T3) and thyroxine (T4) serum levels in old age. Horm Metab Res 1974; 6: 239 - 240.

16. Nishikawa M, Inada M, Naito K, et al. Age-related changes of 3,3'-diiodothyronine, 3',5'-diiodothyronine, and 3,5-diiodothyronine concentrations in man. J Clin Endocrinol Metab 1981; 52: 517- 522.

17. Smals AGH, Ross HA, Kloppenburg SWC. Seasonal variation in serum T3 and T4 levels in man. J Clin Endocrinol Metab 1977; 44: 998 - 1001. 
18. Overgaard K, Nilas L, Johansen JS, Christiansen C. Lack of seasonal variation in bone mass and biochemical estimates of bone turnover. Bone 1988; 9: 185-288

19. Beresford JN, Gallagher JA, Poser JW, Russell RGG. Production of osteocalcin by human bone cells in vitro. Effects of $1,25(\mathrm{OH})_{2} \mathrm{D} 3,24,25(\mathrm{OH})_{2} \mathrm{D} 3$, parathormone and glucocorticoids. Metab Bone Dis Rel Res 1984; 5: 229 - 234.

20. Kaplan GC, Eilon G, Poser JW, Jacobs JW. Constitutive biosynthesis of bone Gla-protein in a human osteosarcoma cell line. Endocrinol 1985; 117: 1235 - 1238.

21. Morrison NA, Shine J, Fragonas JC, Verkest V, McMenemy MC, Eisman JA. 1,25dihydroxyvitamin D-responsive element and glucocorticoïd repression in the osteocalcin gene. Science 1989; 246: 1158 - 1161

22. Nielsen HK, Brixen K, Kassem M, Mosekilde L. Acute effect of 1,25-dihydroxyvitamin D3, prednisone and 1,25-dihydroxyvitamin D3 plus prednisone on serum osteocalcin in normal individuals. J Bone Min Res 1991; 6: 435 - 441.

23. Rizolli R, Poser J, Burgi U. Nuclear thyroid hormone receptors in cultured bone cells. Metab 1986; 35: 71 - 74.

24. Garrel R, Delmas PD, Malaval L, Toumiaire J. Serum bone Gla-protein: A marker of bone turnover in hyperthyroidism. J Clin Endocrinol Metab 1986; 62: 1052 - 1055.

25. Lee MS, Kim SY, Lee MC, et al. Negative correlation between the change in bone mineral density and serum osteocalcin in patients with hyperthyroidism. J Clin Endocrinol Metab
1990; 70: 766 - 770.

26. Ross DS, Ardisson LJ, Nussbaum R, Meskell MJ. Serum osteocalcin in patients taking L-thyroxine who have subclinical hyperthyroidism. J Clin Endocrinol Metab 1991; 72:
507-509. 27. Delmas PD, Wahner HW, Mann KG, Riggs B. Assessment of bone turnover in
postmenopausal osteoporosis by measurement of serum bone Gla-protein. J Lab Clin Med
1983; 102: $470-476$. $1983 ; 102: 470$ - 476.

28. Johansen JS, Riis BJ, Delmas PD, Christiansen C. Plasma BGP; an indicator of spontaneous bone loss and of the effect of oestrogen treatment in postmenopausal women. Eur
J Clin Invest 1988; 18: 191 - 195.

29. Rapado A, De la Piedra C, Torres R. BGP (osteocalcin, bone Gla-protein) in involutional osteoporosis. Clin Rheumatol 1989; 8 suppl: 30 - 34 .

30. Barentsen R, Raymakers JA, Landman JO, Duursma SA. Bone mineral content of the forearm in healthy Dutch women. Maturitas 1988; 10: $231-241$.

31. Van Berkum FNR, Pols HAP, Kooij PPM, Birkenhäger JC. Peripheral and axial bone mass in Dutch women. Relations to age and menopausal state. Neth J Med 1988; 32: 226

32. Slemenda ChW, Hui SL, Williams ChJ, Christian JC, Meaney FJ, Johnston Jr. CC. Bone mass and anthropometric measurements in adult female. Bone Min 1990; 11: $101-109$.

33. Van Beresteijn ECh, van Laarhoven JPRM, Smals AGH. Body weight and/or endogenous estradiol as determinants of cortical bone mass and bone loss in healthy early postmenopausal women. Acta Endocrinol 1992; 127: 226 - 230.

34. Ribot C, Tremollieres F, Pouilles JM, Bonneu M, Germain F, Louvet JP. Obesity and postmenopausal bone loss: the influence of obesity on vertebral density and bone tumover
in postmenopausal women. Bone $1987 ; 8: 327-331$. . 


\section{Chapter 4}

\section{PERIPHERAL BONE DENSITY IN WOMEN WITH UNTREATED MULTINODULAR GOITRE.}

A.H. Mudde, F.J.L. Reijnders and A.C. Nieuwenhuijzen Kruseman

Published in: Clinical Endocrinology 1992; 37: 35-39. 
OBJECTIVES: We wished to determine whether women with multinodular goitre and spontaneous subclinical hyperthyroidism have decreased bone density.

DESIGN AND SUBJECTS: Bone density was measured at the distal and proximal forearm. Data were expressed as Z-scores relative to the mean values out of 125 control subjects matched for age and menopause. The Z-scores of 23 women with subclinical hyperthyroid goitre (TSH $<0.1 \mathrm{mU} / \mathrm{l}$ and normal values of FT4 and total T3) and of 54 women with euthyroid goitre were compared.

MEASUREMENTS: Bone density was measured by single photon absorptiometry. TSH was measured by IRMA, FT4 by RIA.

RESULTS: Relative to the euthyroid goitre subjects the mean \pm SEM Z-scores of both the distal and proximal forearm density were lower $(-0.69 \pm 0.17$ vs $-0.1 \pm 0.18, P<0.05$ and $-0.5 \pm 0.18$ vs $0.07 \pm 0.18, P<0.05$, respectively). Median (range) FT4 in the subclinical hyperthyroid goitre subjects was significantly higher than in the euthyroid goitre subjects $(15.6(11-23.2) \mathrm{pmol} / \mathrm{l}$ vs 11.9 (8.3 - 18.3) $\mathrm{pmol} / 1, \mathrm{P}<0.001$ ), although still within the normal range. FT4 correlated inversely with Z-scores of both distal and proximal forearm bone density in the subjects with subclinical hyperthyroidism $(r=-0.42, P<0.05$ and $r=-0.45, P<0.05$, respectively), but not in the euthyroid goitre subjects.

CONCLUSION: These findings indicate that women with untreated multinodular goitre and subclinical hyperthyroidism have reduced bone density in the forearm. 


\section{INTRODUCTION}

Hyperthyroidism is a well known cause of osteoporosis (Fraser et al., 1971; Bayley et al., 1980; Lee et al., 1990). Recent studies have shown that long-term suppressive treatment with L-thyroxine may reduce bone density (Ross et al., 1987; Paul et al., 1988). These reports suggest that even small increases in thyroid hormone levels may contribute to loss of bone density. To investigate the possibility that spontaneous subclinical hyperthyroidism (suppressed TSH in combination with normal thyroid hormone levels) can interfere with bone density we measured peripheral bone density in women with untreated multinodular goitre and laboratory tests consistent with subclinical hyperthyroidism. In accordance with our earlier finding that TSH values $<0.1 \mathrm{mU} / \mathrm{l}$ have a high predictive value (p.v. $=1$ ) for a flat TSH-response in a TRH-test (Mudde et al., 1987) we considered TSH values below $0.1 \mathrm{mU} / \mathrm{A}$ as suppressed. The data obtained from the bone density measurements in the subjects with subclinical hyperthyroidism related to controls matched for age and menopause were compared to age and menopause-corrected data obtained from euthyroid subjects with goitres.

\section{SUBJECTS AND METHODS}

\section{Subjects}

Subjects were selected from adult women under 70 years attending the outpatient Clinic, meeting the following criteria: multinodular goitre, confirmed by

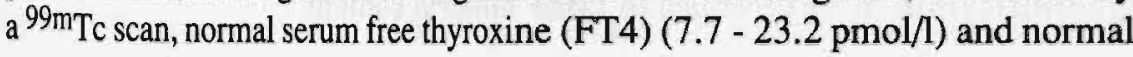
or suppressed serum TSH (TSH $<3.5 \mathrm{mU} / \mathrm{l}$ ). If the serum TSH was suppressed (TSH $<0.1 \mathrm{mU} / \mathrm{l})$ serum triidothyronine was determined to exclude "T3thyrotoxicosis".

Excluded were subjects with coexisting disease or treatment known to influence thyroid or bone metabolism or with a past history of thyroid dysfunction. Subjects who had been treated with radioactive iodine or by thyroid surgery were excluded as well.

The ages of all subjects were determined to the nearest month. The subjects were divided into two groups. Group I consisted of 23 (six pre- and 17 postmenopausal) subjects with subclinical hyperthyroidism, median age (range) $57.2(37-70.7)$ years. The post-menopausal subgroup ranged from 1.6 to 23.7 years since the menopause. The mean \pm SEM body weight was $67.9 \pm 1.8 \mathrm{~kg}$. 
Group II consisted of 54 ( 29 pre- and 25 post-menopausal) euthyroid goitre subjects, median age (range) 48.6 (24 - 69.8) years. The post-menopausal subgroup ranged from 1.5 to 22.5 years since the menopause. The mean \pm SEM body weight was $71.3 \mathrm{~kg} \pm 1.5 \mathrm{~kg}$.

One hundred and twenty-five female control subjects ( 78 pre- and 47 postmenopausal) between 20 and 75 years were recruited from the hospital staff and from patients with minor medical problems, known to have no influence on bone density or thyroid function, attending the Internal or the Gynaecology out-patient Clinic. The mean \pm SEM body weight of the control group was 70.3 $\pm 1.2 \mathrm{~kg}$

\section{Methods}

Bone mineral content (BMC) was measured in the non-dominant forearm by single photon absorptiometry (Nuclear Data NDI 1100 A, USA). Measurements are reported as the ratio of $\mathrm{BMC}$ to bone width (DBMC/BW and PBMC/BW for the distal and proximal site respectively) and are expressed in arbitrary units. Reproducibility of the method was assessed by five repeated measurements in five healthy volunteers within 2 weeks. The coefficients of variation of $\mathrm{DMBC} / \mathrm{BW}$ and $\mathrm{PBMC} / \mathrm{BW}$ were 3.1 and $1.9 \%$ respectively.

Serum FT4 was determined by the SPAC-FT4-fraction test (BYK-Sangtec Diagnostica, Germany). Serum TSH was determined by IRMA (CIS, France). Intra-assay variations at TSH concentrations of $0.4,2.2$ and $10.5 \mathrm{mU} / 1$ were 8.0, 6.5 and $6.1 \%$ respectively. The detection limit of the TSH-assay was $0.02 \mathrm{mU} / \mathrm{l}$.

\section{Quantification of differences in bone mineral content}

In premenopausal subjects the BMC of each goitre subject was paired with the mean BMC (called "reference BMC") of premenopausal control subjects of the same age ( \pm 2.5 years) as the subject under investigation. The differences between the observed values of BMCs for each subjects and the reference BMC were divided by the SD of the reference BMC to obtain age specific Z-scores of BMCs (Parfitt, 1990). In post-menopausal subjects the number of years since the menopause was used instead of chronological age to calculate Z-scores. Subjects were considered as post-menopausal if the last uterine bleeding was at least one year before. In those post-menopausal subjects whose years since menopause were less than 3.5 years, Z-scores were calculated from data obtained from pre- and post-menopausal controls respectively, in the way as
described above. 
Data from the groups are expressed as mean \pm SEM, or median (range) when not normally distributed. Differences between groups were compared by unpaired Student's t-test and Wilcoxon's rank sum test when appropriate. Twotailed P-values below 0.05 were considered statistically significant. Pearson's correlation coefficient for linear regression was used to determine the relationship between two variables.

\section{RESULTS}

In the total group of subclinical hyperthyroid goitre subjects (group I) the $\mathrm{DBMC} / \mathrm{BW}$ vs the DBMC/BW in the age matched controls $(\mathrm{n}=95)$ was $0.78 \pm$ 0.03 vs $0.93 \pm 0.02(\mathrm{P}<0.01)$. The $\mathrm{PBMC} / \mathrm{BW}$ in group $\mathrm{I}$ vs the $\mathrm{PBMC} / \mathrm{BW}$ in the age matched controls $(n=95)$ was $1.09 \pm 0.04$ vs $1.22 \pm 0.02(P<0.01)$. In the total group of euthyroid goitre subjects (group II) the DBMC/BW vs the $\mathrm{DBMC} / \mathrm{BW}$ in the age matched controls $(\mathrm{n}=125)$ was $0.95 \pm 0.02$ vs $0.95 \pm$ 0.01 (NS). The PBMC/BW in group II vs the $\mathrm{PBMC} / \mathrm{BW}$ in the age matched controls $(n=125)$ was $1.25 \pm 0.02$ vs $1.24 \pm 0.02$ (NS).

Individual values of Z-scores of BMCs of the goitre subjects are shown in Figs. 1 and 2. The Z-scores of both $\mathrm{DBMC} / \mathrm{BW}$ and $\mathrm{PBMC} / \mathrm{BW}$ in group I were significantly lower than in group II as shown in Table 1. No correlations between Z-scores of BMCs and age were found in either group (data not shown).

Serum FT4 in group I was significantly higher than in group II as shown in Table 1. In group I there was an inverse correlation between FT4 and Z-score of $\mathrm{DBMC} / \mathrm{BW}(\mathrm{r}=-0.42, \mathrm{P}<0.05)$ and between FT4 and Z-score of PBMC/BW $(r=-0.45, P<0.05)$ (Figs. 3 and 4$)$. In group II and the healthy controls there was neither correlation between FT4 and BMCs nor between TSH and BMCs (data not shown). 


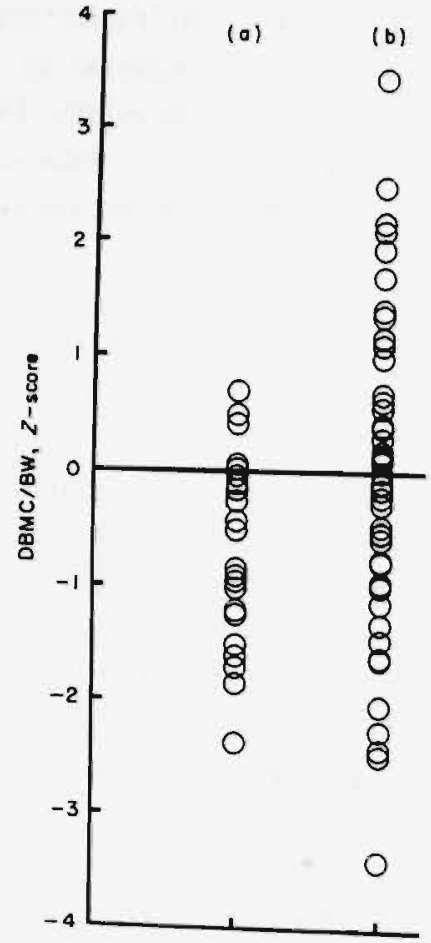

\section{Figure 1}

Bone mineral content to bone width ratio in distal forearm of (a), subclinical hyperthyroid and (b), euthyroid goitre subjects.

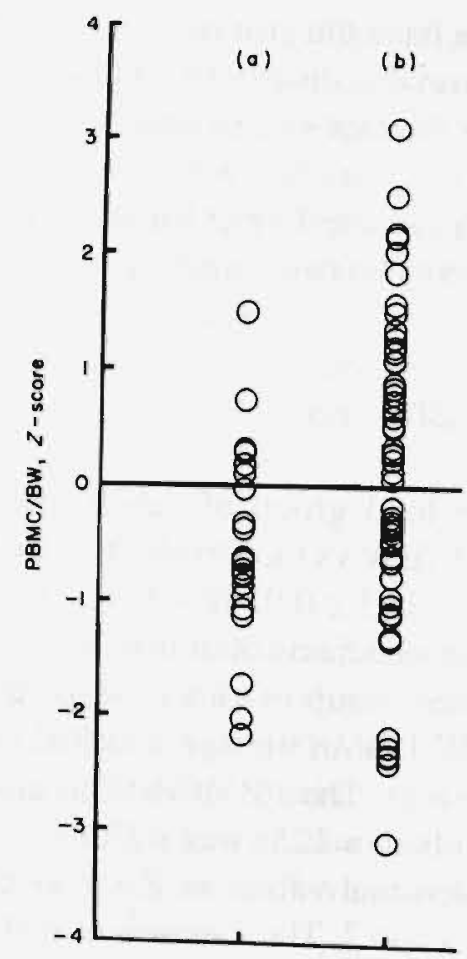

Figure 2

Bone mineral content to bone width ratio in proximal forearm of (a), subclinical hyperthyroid and (b), euthyroid goitre subjects.

\section{Table 1}

Thyroid function and bone mineral content in euthyroid (EG) and subclinical hyperthyroid
(SHG) subjects with goitre.

\begin{tabular}{llll}
\hline & EG & SHG & P-value \\
\hline FT4 (pmol/l) & $11.9(8.3-18.3)$ & $15.6(11.0-23.2)$ & $<0.001$ \\
TSH (mU/n) & $1.0(0.1-2.7)$ & $<0.1$ & \\
BMC (Z-score) & & & \\
distal & $-0.1 \pm 0.18$ & $-0.69 \pm 0.17$ & 0.027 \\
proximal & $0.07 \pm 0.18$ & $-0.5 \pm 0.18$ & 0.032 \\
\hline
\end{tabular}

Values median (range) or mean $\pm \mathrm{SEM}$. 


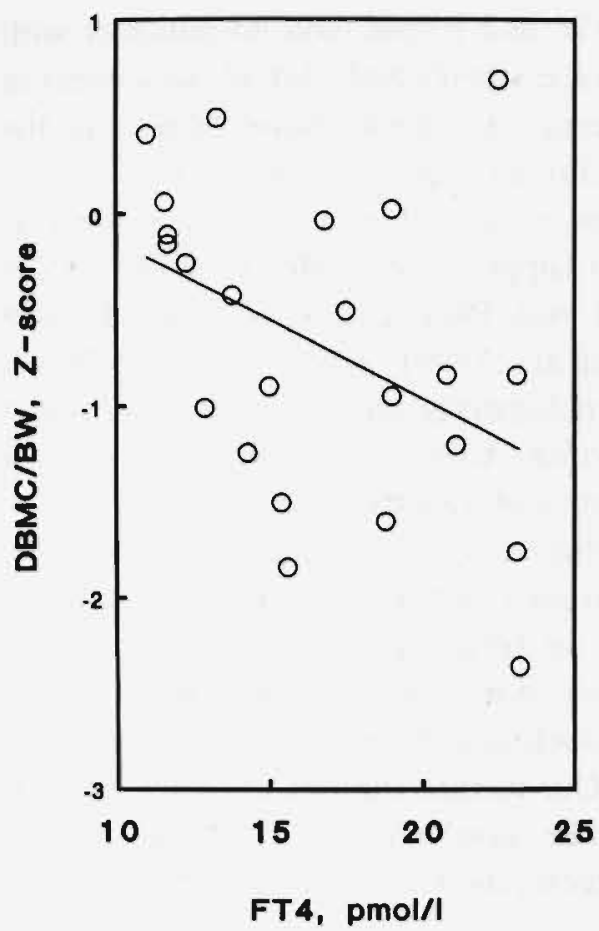

Figure 3

Relation of free thyroxine level to distal bone mineral content to width ratio in subclinical hyperthyroid goitre subjects $(y=0.67$ $0.08 x ; r=-0.42 ; P<0.05$ ).

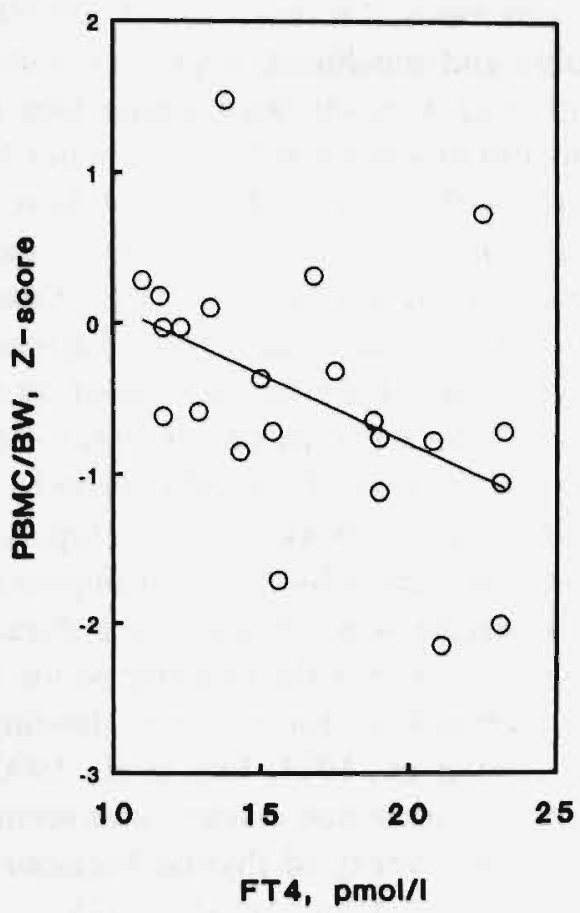

Figure 4

Relation of free thyroxine level to proximal bone mineral content to width ratio in subclinical hyperthyroid goitre subjects $(y=1$ $0.09 x ; r=-0.45 ; P<0.05$ ).

\section{DISCUSSION}

The differences in absolute values of BMCs between groups is biased by differing numbers of subjects at different ages. Transformation of bone mineral density to Z-scores has proved to be an efficient technique for quantification of differences in bone density between groups (Parfitt, 1990). As possible differences in bone mass due to thyroid dysfunction could be partly mediated by the influence of thyroid hormones on body mass, we did not match the control subjects for body weight. 
The mean Z-scores of both DBMC/BW and PBMC/BW in subjects with goitre and subclinical hyperthyroidism were significantly lower than those in euthyroid subjects with goitre. Our finding of reduced bone density at the forearm in women with spontaneous subclinical hyperthyroidism may be compared with recent studies which have shown reduced bone density in subjects with subclinical hyperthyroidism due to suppressive treatment with thyroid hormones (Diamond et al., 1991; Kung \& Pun, 1991; Paul et al., 1988; Ross et al., 1987; Stall et al., 1990; Taelman et al., 1990). Some studies however suggest that this could be caused by overt hyperthyroidism in the past, rather than by the actual treatment with L-thyroxine (Adlin et al., 1991; Greenspan et al., 1991). None of our subjects had a history of hyperthyroidism.

Ross and co-workers (1987) reported that the decreased bone density in the non-dominant radius in premenopausal women treated with excessive doses of L-thyroxine was related to the duration of treatment, rather than to the Lthyroxine dose or the resulting serum levels of thyroid hormones. In particular, in multinodular goitre a long-standing subclinical hyperthyroidism may exist (Evered et al., 1974; Elte et al., 1990). Our results support the view that the degree of reduction in bone mass seems to be correlated with the duration rather than the severity of thyroid hormone excess, as was shown before in hyperthyroidism (Meunier et al., 1972).

The median FT4 in the subjects with goitre and subclinical hyperthyroidism, although still in the normal range, was higher than that in euthyroid subjects with goitre. This is in accordance with studies that show that subjects with low TSH and normal T3 and T4 have slightly elevated levels of FT4 when compared with subjects with TSH within the normal range (Caldwell et al., 1985; 0'Malley et al., 1989). FT4 correlated inversely with the Z-scores of both $\mathrm{DBMC} / \mathrm{BW}$ and PBMC/BW in the patients with goitre and suppressed TSH. A similar correlation was reported between the free thyroxine index and Z-score of bone mass of the femoral neck in L-thyroxine treated subjects (Kung \& Pun, 1991). In both euthyroid goitre subjects and the control subjects in our study there was no correlation between FT4 and Z-scores of BMCs or TSH and $\mathrm{Z}$-scores of BMCs, indicating that in the normal range of TSH different levels of FT4 have no impact on bone mass at the forearm. Our data indicate that normal TSH represents euthyroidism at the level of bone and suppressed TSH represents "tissue thyrotoxicosis" at the level of bone with an increasing effect on forearm bone density with rising titres of FT4.

In conclusion, women with untreated multinodular goitre and spontaneous subclinical hyperthyroidism have reduced bone density at both the distal and proximal forearm in comparison with euthyroid goitre subjects. The reduction 
in bone density correlates with FT4 levels. Our results suggest that antithyroid treatment in subclinical hyperthyroidism may be beneficial, although the effect of this treatment on bone density has yet to be established.

\section{Acknowledgements}

We are indebted to the personnel of "de interne functieafdeling" for their assistance in performing the bone density measurements and to Dr. C. Johnston, Surgeon Commander in the Royal Navy, for his critical comments on the manuscript. 


\section{REFERENCES}

Adlin E.V., Maurer A.H., Marks A.D. \& Channick B.J. (1991) Bone mineral density in postmenopausal women treated with L-thyroxine. American Joumal of Medicine, 90 , 360-366.

Bayley T.A., Harrison J.E., McNeill K.G. \& Memagh J.R. (1980) Effect of thyrotoxicosis and its treatment on bone mineral and muscle mass. Joumal of Clinical Endocrinology and Metabolism, 50, 916-922.

Caldwell G., Gow S.M. Sweeting V.M., Kellett H.A. Beckett G.J. \& Seth J. (1985) A new strategy for thyroid function testing. Lancet, $i, 1117-1119$.

Diamond T, Nery L. \& Hales I. (1991) A therapeutic dilemma: Suppressive doses of thyroxine significantly reduce bone mineral measurements in both premenopausal and postmenopausal women with thyroid carcinoma. Journal of Clinical Endocrinoloy and Metabolism, 72, 1184-1188.

Elte J.W.F., Bussemaker J.K. \& Haak A. (1990) The natural history of euthyroid multinodular goitre. Postgraduate Medical Journal, 66, 186-190.

Evered D.C., Clark F. \& Petersen V.B. (1974) Thyroid function in euthyroid subjects with autonomous thyroid nodules. Clinical Endocrinology, 3, 149-154.

Fraser S.A., Anderson J.B., Smith D.A. \& Wilson G.M. (1971) Osteoporosis and fractures following thyrotoxicosis. Lancet, i, 981-983.

Greenspan S.L., Greenspan F.S. Resnick N.M., Block J.E., Friedlander A.L. \& Genant H.K. (1991) Skeletal integrity in premenopausal and postmenopausal women receiving longterm L-thyroxine therapy. American Journal of Medicine, 91, 5-14.

Kung A.W.C. \& Pun K.K. (1991) Bone Mineral Density in Premenopausal women receiving long-term physiological doses of levothyroxine. Joumal of the American Medical Association, 265, 2688-2691.

Lee M.S., Kim S.Y., Lee M.C., Cho B.Y., Lee H.K., Koh C.S. \& Min H.K. (1990). Negative correlation between the change in bone mineral density and serum osteocalcin in patients with hyperthyroidism. Journal of Clinical Endocrinology and Metabolism, 70, 766-770.

Meunier P.J., Bianchi G.G.S., Edouard C.M., Eng B.S., Bernard J.C., Coupron P. \& Vignon G.E. (1972) Bony manifestations of thyrotoxicosis. Orthopedic Clinics of North America, 3, 745-774.

Mudde A.H., Bastiaanse A.J. \& Jonkers H. (1987) TSH-IRMA als eerste diagnosticum bij vermoeden van hyperthyroïdie. Nederlands Tijdschrift van Geneeskunde, 131, 23642368.

O'Malley B.P., Rosenthal F.D., Exley A., Farconer-Smith J.F., Mahabir J. \& Woods K.L. (1989) Low serum TSH with normal total thyroid hormone levels: an indicator of free T4 excess. Clinical Endocrinology, 30, 627-634.

Parfitt A. (1990) Interpretation of bone densitometry measurements: disadvantages of a percentage scale and a discussion of some alternatives. Journal of Bone and Mineral Research, 5, 537-540.

Paul T.P., Kerrigan J. Kelly A.M., Braverman L.E. \& Baran D.T. (1988) Long-term Lthyroxine therapy is associated with decreased hip bone density in premenopausal women. Joumal of the American Medical Association, 259, 3137-3141. 
Ross D.S., Neer R.M., Ridgway E.C. \& Daniels G.H. (1987) Subclinical hyperthyroidism and reduced bone density as a possible result of prolonged suppression of the pituitarythyroid asis with L-thyroxine. American Journal of Medicine, 82, 1167-1172.

Stall G.M., Harris S., Sokoll L.J. \& Dawson-Hughes B. (1990) Accelerated bone loss in hypothyroid patients overtreated with L-thyroxine. Annals of Internal Medicine, 113, 265-26.

Taelman P., Kaufman J.M., Janssens X., Vandecauter H. \& Vermeulen A. (1990) Reduced forearm bone mineral content and biochemical evidence of increased bone turnover in women with euthyroid goitre treated with thyroid hormone. Clinical Endocrinology, 33, 107-117. 


\section{Chapter 5}

\section{BONE TURNOVER IN WOMEN WITH SUBCLINICAL HYPERTHYROID MULTINODULAR GOITRE}

A.H. Mudde, F.J.L. Reijnders, H. Jonkers, A.J. Bastiaanse, A.C. Nieuwenhuijzen Kruseman.

Submitted for publication 
In 77 consecutively selected women with nontoxic multinodular goitre 23 subjects had subclinical hyperthyroidism as defined by suppressed basal serum TSH values (TSH $<0.1 \mathrm{mU} /$ ) in combination with normal serum thyroid hormone levels. These subjects had a significantly higher median age and serum FT4 than the remaining 54 euthyroid goitre subjects $(57$ (37-71) vs 48.5 (24 -69) years; $\mathrm{P}=0.0064$, resp. $16.9(11-23.2)$ vs $12.3(8.3-18.3) \mathrm{pmol} / \mathrm{l} ; \mathrm{P}=$ 0.01 ). Both median (range) serum osteocalcin and serum alkaline phosphatase were higher in the subclinical hyperthyroid than in the euthyroid goitre subjects (12.4 (6.7-19.6) vs $9.9(4.6-18.8) \mu \mathrm{g} / \mathrm{l}, \mathrm{P}$ $=0.01$, resp. 74 (42-95) vs $55(29-94) \mathrm{U} / \mathrm{l} ; \mathrm{P}=0.0034)$. Expression of osteocalcin values as Z-scores showed that the difference in osteocalcin was not due to the difference in age between the two groups. Both in the euthyroid and in the subclinical hyperthyroid goitre subjects osteocalcin was significantly correlated with alkaline phosphatase $(y=4.3998+0.0997 \mathrm{x} ; \mathrm{r}=0.51 ; \mathrm{P}<0.001$ and $y=5.4362+0.0997 x ; r=0.45 ; P=0.0313$, resp.). These data indicate that women with subclinical hyperthyroid multinodular goitre have increased bone turnover, which may indicate a risk for increased loss of bone. 
In a recent study we have shown that women with subclinical hyperthyroidism due to multinodular goitre have a decreased forearm bone mineral density (1). This may be due to increased bone turnover, as has been found in overt hyperthyroidism ( 2 - 4). Osteocalcin has been shown to be a useful parameter of bone turnover in metabolic bone disease $(5-8)$. We have previously reported preliminary results of serum osteocalcin measurements in women with multinodular goitre (9). Here we report extended data concerning osteocalcin and alkaline phosphatase measurements in women with untreated subclinical hyperthyroid multinodular goitres in comparison with data obtained in women with euthyroid goitres.

\section{SUBJECTS AND METHODS}

Details of the patient groups are described elsewhere (1). In short, consecutively selected women with untreated nontoxic multinodular goitre from the outpatient Clinics were divided in a group of 23 women with spontaneous subclinical hyperthyroidism (age ranging from 37 - 70 years) and a group of 54 euthyroid women (age ranging from $24-70$ years). There were 17 postmenopausal women in the subclinical hyperthyroid group (median (range) time since menopause $12.5(1.5$ - 24) years). There were 25 postmenopausal women in the euthyroid group (median (range) time since menopause 8 (1.5 23) years). Women with co-existing diseases or taking drugs known to influence thyroid, bone or liver metabolism were excluded. Subclinical hyperthyroidism was defined as suppressed basal serum TSH (TSH $<0.1 \mathrm{mU} / \mathrm{1})$ in combination with normal serum levels of FT4 and total T3. Serum T3 values were only determined in women with suppressed TSH to exclude T3thyrotoxicosis and are not further considered here. Osteocalcin was determined in cooled morning sampled serum, using a bovine RIA method (CIS, France). The intra- and interassay variations in the normal range were $1.7 \%$ and $6.3 \%$ respectively. In a study in healthy women we have found a significant correlation between the serum osteocalcin concentration and age $(y=23.8654$ $\left.1.0803 x+0.0243 x^{2}-0.0002 x^{3}, r=0.39 ; P=0.0002\right)$ with a mean ( $\pm S D$ ) serum osteocalcin concentration of $10.1 \pm 2.9 \mu \mathrm{g} / \mathrm{l}$ (details described in Chapter 3 ). We therefore corrected the individual data in the goitre subjects by calculating Z-scores in comparison with 125 healthy females, matched for age and menopause $( \pm 2,5$ years). 


$$
Z-\text { score }=\frac{\text { subjects value }- \text { mean reference value }}{\text { SD mean reference value }}
$$

Total serum alkaline phosphatase was determined by an auto-analyzer (Hitachi 717) using a routine calorimetric method with p-nitrofenyl- phosphate as substrate at a temperature of $30^{\circ} \mathrm{C}$. The reference range of serum alkaline phosphatase was $30-105$ U/l. Serum TSH, determined by a second generation IRMA (CIS, France), had intra-assay and interassay variations ranging from $3.9 \%$ to $10 \%$ in the normal and low range of TSH, respectively. Serum FT4 was determined by the "SPAC-FT4-fraction test" (Byk - Sangtec Diagnostica, Germany). The intra- and interassay variation in the normal range (7.7 - 23.2 $\mathrm{pmol} / \mathrm{l}$ ) were $6.7 \%$ and $8.7 \%$, respectively.

Data are expressed as median (range), unless otherwise stated. Differences between groups were compared with Mann - Whitney's U test. $\mathrm{P}<0.05$ was considered statistically significant. Pearson's correlation-coefficient for linear regression was used to determine the relationship between two variables.

\section{RESULTS}

The subjects with subclinical hyperthyroidism were significantly older than the euthyroid subjects (table 1). Median serum FT4 was significantly higher in subclinical hyperthyroid goitre subjects than in the subjects with euthyroid goitre, although all values were within the normal range (table 1). Both median serum osteocalcin and alkaline phosphatase were significantly higher in the subclinical hyperthyroid goitre subjects than in the subjects with euthyroid goitre (table 1). When the osteocalcin data were corrected for age and

\section{Table 1}

Median (range) of ages and biochemical parameters of bone turnover and thyroid function in women with subclinical hyperthyroid goitre (SHG) and euthyroid goitre (EG).

\begin{tabular}{|c|c|c|c|}
\hline & $\begin{array}{l}\text { SHG } \\
(n=23)\end{array}$ & $\begin{array}{l}\text { EG } \\
(n=54)\end{array}$ & $\mathrm{P}$ \\
\hline age (years) & $57(37-71)$ & $48.5(24-69)$ & 0.006 \\
\hline TSH $(\mathrm{mU} / \mathrm{l})$ & $<0.1$ & $1.0(0.1-2.7)$ & \\
\hline FT4 $(\mathrm{pmol} / \mathrm{l})$ & $16.9(11-23.2)$ & $12.3(8.3-18.3)$ & $<0.0001$ \\
\hline osteocalcin $(\mu \mathrm{g} / l)$ & $12.4(6.7-19.6)$ & $9.9(4.6-18.8)$ & 0.01 \\
\hline alkaline phosphatase (U/L) & $74(42-95)$ & $55(29-94)$ & 0.0034 \\
\hline
\end{tabular}


menopause the difference was significant as well ( $\mathrm{Z}$-score osteocalcin in subclinical hyperthyroid versus euthyroid women 0.33 (- 1.57 to 3.83 ) vs -0.16 (2.84 to 3.13 ) $\mathrm{P}=0.0225$ ) (fig. 1).

Both in the euthyroid and in the subclinical hyperthyroid subjects there was a significant correlation between serum osteocalcin and serum alkaline phosphatase (figs. 2 and 3). No correlations were found between either osteocalcin or alkaline phosphatase and thyroid function parameters (data not shown). When the data of both groups, however, were combined significant correlations between both the serum osteocalcin concentration and FT4 $(y=6.38+0.32 x, r$ $=0.36 ; \mathrm{P}=0.0015)$, and between the Z-score of osteocalcin and FT4 $(y=-1.81$ $+0.14 \mathrm{x}, \mathrm{r}=0.36 ; \mathrm{P}=0.0013$ ) were observed.

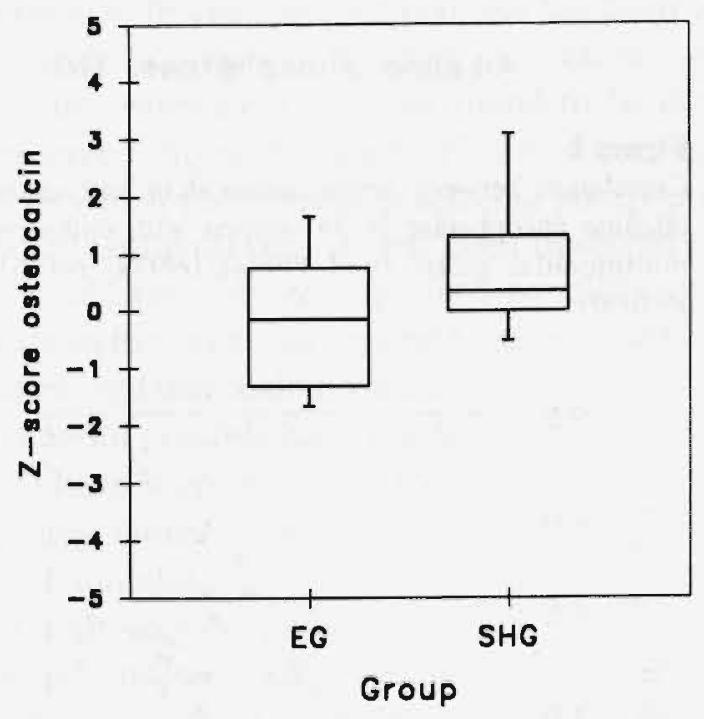

Figure 1

Box-plot (Median, 10th, 25th, 75th and 90th percentile) of the Z-scores of osteocalcin values in women with euthyroid goitre (EG) and subclinical hyperthyroid goitre (SHG). 


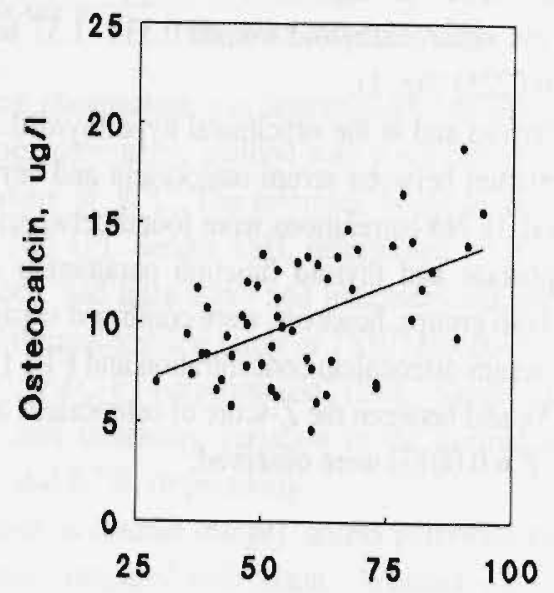

Alkaline phosphatase, U/I

\section{Figure 2}

Correlation between serum osteocalcin and serum alkaline phosphatase in 54 women with euthyroid multinodular goitre $(y=4.3998+0.0997 x ; r=0.51$; $\mathrm{P}<0.001)$.

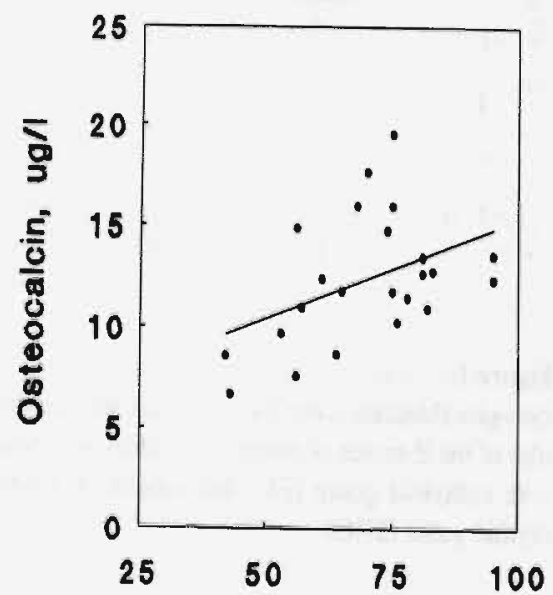

\section{Figure 3}

\section{Alkaline phosphatase, U/I}

Correlation between serum osteocalcin and serum alkaline phosphatase in 23 women with subclinical hyperthyroid multinodular goitre $(y=5.4362+$ $0.0997 x ; r=0.45 ; P=0.0313$ ). 
In overt hyperthyroidism bone turnover may be increased, which is biochemically indicated by increased levels of serum alkaline phosphatase, osteocalcin and urinary excretion of hydroxyproline and pyridinium cross-links (10 - 16). Histomorphometric studies have revealed that the major abnormality in hyperthyroid bone is an increased bone turnover rate. There are no signs of uncoupling between osteoblastic and osteoclastic activity $(2-4)$. Although basicly reflecting bone formation, osteocalcin may be regarded as a parameter of bone turnover if coupling between osteoblasts and osteoclasts is intact $(7,8)$.

Most of the information available about bone turnover in subclinical thyrotoxicosis is derived from L-thyroxine treated subjects. In some studies a slight increase in mean serum alkaline phosphatase in subclinical thyrotoxic subjects in comparison with age matched controls has been observed $(17,18)$. Individual values in these subjects, however, are mostly within the normal range $(17,18)$. Serum osteocalcin also has found to be elevated in subjects treated with suppressive L-thyroxine doses $(17,18)$. These data are at variance with other studies in which no increase in alkaline phosphatase or osteocalcin in exogenous subclinical thyrotoxicosis has been observed $(16,19-21)$. The discrepant results could possibly be explained by different matching procedures, or by variance in the extend of thyroid hormone excess. In some of these studies trends to increased osteocalcin values in L-thyroxine treated subclinical thyrotoxic subjects could possibly have reached significance if the rather small study groups would have been extended $(16,20)$.

In the present study untreated women with endogenous subclinical hyperthyroidism due to multinodular goitre had higher median values than euthyroid controls of both serum alkaline phosphatase and osteocalcin. The individual values of alkaline phosphatase, however, were all within the normal range. Because of age-and assay-related variations in normal osteocalcin values it has recently been advocated to express data of osteocalcin as a percentage of reference values in an appropriate population of normal individuals (22). Eliminating a possible bias by age-related differences in standard deviation of normal osteocalcin values we prefered, according to Duda et al. (23), to express the osteocalcin data as Z-scores rather than as percentages. Correction of the data in this way showed that there was still a difference in median osteocalcin between the subclinical hyperthyroid and euthyroid goitre subjects, which could therefore not be due to the difference in age between the two groups. Our findings are in agreement with those of Faber et al.(24) who have reported 
increased levels of both absolute and relative (as a percentage of age matched controls) osteocalcin values in spontaneous subclinical hyperthyroidism and confirm our pilot study (9).

In our preliminary data we have found a correlation between the serum osteocalcin and FT4 concentrations, when the data of euthyroid and subclinical hyperthyroid goitre subjects were grouped together (9). In the present study this relation was confirmed, but we could not find a correlation between osteocalcin and any of the thyroid function parameters in the separate groups. This is in agreement with most other studies in both overt and subclinical thyrotoxicosis $(13,15,17,18)$.In the healthy population serum osteocalcin and alkaline phosphatase are well correlated (25). The correlation between serum osteocalcin and alkaline phosphatase in the euthyroid goitre subjects in the present study is in agreement with these data. In some metabolic bone diseases, a discrepancy between serum osteocalcin and alkaline phosphatase may exist $(5,23)$. As total alkaline phosphatase may partly reflect an increased liver fraction in thyroid hormone excess $(10,12)$, osteocalcin may more accurately reflect the increased bone metabolism in this condition. Data in overt hyperthyroidism, however, indicate that in this condition no dissociation between these two parameters exists $(14,23-26)$. Our data show that in endogenous subclinical hyperthyroidism serum osteocalcin and alkaline phosphatase are correlated as well.

Biochemical parameters of bone metabolism, including osteocalcin, do not correlate very well with actual bone density (Chapter $3,27,28$ ). High osteocalcin values, however, may indicate future bone loss (29). Since subclinical hyperthyroidism in multinodular goitre may exist for many years (30) our data of increased osteocalcin values in women with subclinical hyperthyroid multinodular goitre may indicate that these subjects are at risk for increased bone loss. This is in agreement with the decreased forearm bone density, which we have previously documented in this group of subjects (1).

In conclusion the results of thyroid function tests in women with endogenous subclinical hyperthyroidism due to multinodular goitre are suggestive for thyroid hormone excess as indicated by suppressed basal serum TSH levels and a slightly elevated median serum FT4 concentration in comparison with euthyroid goitre subjects. Our data indicate that these subjects have increased bone turnover in comparison with euthyroid goitre subjects, which may indicate a risk for increased loss of bone. 
1. Mudde AH, Reijnders FJL, Nieuwenhuijzen Kruseman AC. Peripheral bone density in women with untreated multinodular goitre. Clin Endocrinol, 1992; 37: 35-39.

2. Meunier PJ, Bianchi GG, Edouard CM, Bemard JC, Courpron P, Vignon GE. Bony manifestations of thyrotoxicosis. Orth Clin North Am, 1972; 3: 745-774.

3. Melsen $F$ and Mosekilde L. Morphometric and dynamic studies of bone changes in hyperthyroidism. Acta Path Microbiol Scand Sect A, 1977; 85: 141-150.

4. Eriksen EF, Mosekilde L, Melsen F. Trabecular bone remodeling and bone balance in hyperthyroidism. Bone 1985; 6: 421-428.

5. Price PA, Parthemore JG, Deftos LJ. New Biochemical Marker for bone metabolism. J Clin Invest, 1980; 66: 878-883.

6. Slovik DM, Gundberg CM, Neer RM, Lian JB. Clinical evaluation of bone turnover by serum osteocalcin measurements in a hospital setting. J Clin Endocrinol Metab, 1984; 59: 228-230.

7. Deftos LJ. Bone protein and peptide assays in the diagnosis and management of skeletal disease. Clin Chem, 1991; 37: 1143-1148.

8. Tohmé JK, Seibel MJ, Silverberg SJ, Robbins SP, Bilezikian Z. Biochemical markers of bonemetabolism. Z Rheumatol, 1991; 50: 133-141.

9. Mudde AH, Bastiaanse AJ, Jonkers $\mathrm{H}$. Is there a relationship between thyroid function and serum osteocalcin in women with multinodular goitre? A Preliminary report. Neth J Med, 1990; 37: 17-20.

10. Mosekilde L, Christensen SM, Melsen F, Schwartz Sørensen N. Effects of antithyroid treatment on calcium-phosphorus metabolism in hyperthyroidism. I: Chemical Quantities in serum and urine. Acta Endocrinol, 1978; 87: 743-750.

11. Linde $J$ and Friis Th. Osteoporosis in hyperthyroidism estimated by photon absorptiometry. Acta Endocrinol, 1979; 437-448.

12. Bijlsma JWJ, Duursma SA, Roelofs JMM, der Kinderen PJ Thyroid function and bone turnover. Acta Endocrinol, 1983; 104: 42-49.

13. Lukert BP, Higgins JC, Stoskoph MM. Serum osteocalcin is increased in patients with hyperthyroidism and decreased in patients receiving glucocorticoids. J Clin Endocrinol Metab, 1986; 62: 1056-1058.

14. Garrel DR, Delmas PD, Malaval L, Tourniaire J. Serum bone Gla protein: a marker of bone turnover in hyperthyroidism. J Clin Endocrinol Metab, 1986; 62: 1052-1055.

15. Lee MS, Kim SY, Lee MC, et al. Negative correlation between the change in bone mineral density and serum osteocalcin in patients with hyperthyroidism. J Clin Endocrinol Metab, 1989; 70: 766-770.

16. Harvey RD, McHardy KC, Reid IW et al. Measurement of bone collagen degradation in hyperthyroidism and during thyroxine replacement therapy using pyridinium cross-links as specific urinary markers. J Clin Endocrinol Metab 1991; 72: 1189-1194.

17. Taelman P, Kaufman JM, Janssens X, Vandecauter H, Vermeulen A. Reduced forearm bone mineral content and biochemical evidence of increased bone turnover in women with euthyroid goitre treated with thyroid hormone. Clin Endocrinol, 1990; 33: 107-117. 
18. Diamond T, Nery L, Hales I. A therapeutic dilemma: suppressive doses of thyroxine significantly reduce bone mineral measurements in both premenopausal and postmenopausal women with thyroid carcinoma. J Clin Endocrinol Metab, 1990; 72: 1184-1188.

19. Stall GM, Harris S, Sokoll LJ, Dawson-Hughes B. Accelerated bone loss in hypothyroid patients overtreated with L-thyroxine. Ann Intern Med, 1990; 113: 265-269.

20. Ross DS, Ardisson LJ, Nussbaum SR, Meskell MJ. Serum osteocalcin in patients taking L-thyroxine who have subclinical hyperthyroidism. J Clin Endocrinol Metab, 1991, 72:
507-509.

21. Lehmke J, Bogner U, Felsenberg D, Peters H, Schleusener H. Determination of bone mineral density by quantitative computed tomography and single photon absorptiometry in suclinical hyperthyroidism: a risk of early osteopaenia in post-menopausal women. Clin Endocrinol, 1992; 36: 511-517.

22. Delmas PD, Christiansen C, Mann KG, Price PA. Bone Gla protein (osteocalcin) assay standardization report. J Bone Min Res, 1990; 5: 5-11.

23. Duda RJ, O'Brien JF, Katzmann JA, Peterson JM, Mann KG, Riggs BL. Concurrent assays of circulating bone Gla-protein and bone alkaline phosphatase: effects of sex, age, and metabolic bone disease. J Clin Endocrinol Metab, 1988; 66: 951-957.

24. Faber J, Perrild H, Johansen JS. Bone gla protein and sex hormone-binding globulin in nontoxic goiter: parameters for metabolic status at the tissue level. J Clin Endocrinol Metab, 1990; 70: 49-55.

25. Popelier M, Jollivet B, Fouquet, et al. Etude du metabolisme phospho-calcique dans l'hyperthyroïdie. Press Méd 1990; 19: 705 - 708

26. Martinez ME, Herranz L, de Pedro G, Pallardo LF. Osteocalcin levels in patients with hyper- and hypothyroidism. Horm Metabol Res 1986; 18: 212 - 214

27. Epstein S, McClintock R, Bryce G, Poser J, Johnston CC Jr, Hui S. Differences in serum bone Gla protein with age and sex. The Lancet, 1984; i: 307-310.

28. Rapado A, de la Piedra C, Torres R, BGP (osteocalcin, bone-Gla-protein) in involutional osteoporosis. Clin Rheumatol, 1989; 8 suppl: $30-34$

29. Johansen JS, Riis BJ, Delman PD, Christiansen C. Plasma BGP: an indicator of spontaneous bone loss and of the effect of oestrogen treatment in postmenopausal women. Eur J Clin Invest, 1988; 18: 191-195.

30. Elte JWF, Bussemaker JK, Haak A. The natural history of euthyroid multinodular goitre. 


\section{Chapter 6}

\section{SYSTOLIC TIME INTERVALS AND HEART RATE IN WOMEN WITH UNTREATED MULTINODULAR GOITRE}

A.H.Mudde, H. Drost, A.C. Nieuwenhuijzen Kruseman.

Submitted for publication. 
BACKGROUND: Overt hyperthyroidism has a profound effect on the cardiovascular system. More recently altered cardiac performance in subclinical thyrotoxicosis due to L-thyroxine treatment has been recognized. Cardiodynamic performance in endogenous subclinical hyperthyroidism is less well known. This study objected to determine the cardiac effects in this condition.

DESIGN: In a cross-sectional study systolic time intervals and heart rates in 27 women with untreated subclinical hyperthyroidism associated with multinodular goitre were compared to data obtained in 27 women with euthyroid multinodular goitres.

METHODS: Resting heart rates and systolic time intervals were defined as parameters of the cardiac function. Systolic time intervals, expressed as the ratio of the pre-ejection period (PEP) to the left ventricular ejection time (LVET), were obtained from simultaneous electrocardiographic and M-Mode echocardiographic tracings. TSH was measured by IRMA, thyroid hormones by RIA.

RESULTS: Median (range) FT4 in the subclinical hyperthyroid goitre subjects was higher than in the euthyroid goitre subjects (16.3 (10 - 23) $\mathrm{pmol} / \mathrm{l}$ vs $12.2(9.3-18.3) \mathrm{pmol} / \mathrm{l}, \mathrm{P}=0.0002)$, although individual values were all within the reference range. Mean $( \pm S D$ ) heart rate in the subclinical hyperthyroid goitre subjects was significantly higher than in the euthyroid goitre subjects $(89,7 \pm 12.9$ beats $/ \mathrm{min}$ vs $80.0 \pm 14.4$ beats $/ \mathrm{min} ; \mathrm{P}=0.0121)$. There was no difference between the mean ( \pm SD) PEP/LVET ratio in the subclinical hyperthyroid and euthyroid subjects $(0.266 \pm$ 0.049 vs $0.281 \pm 0.048, \mathrm{P}=0.25$ ).

CONCLUSIONS: In endogenous subclinical hyperthyroidism due to multinodular goitre resting heart rate is increased, without changes in PEP/LVET ratios. 
Overt hyperthyroidism has a profound effect on the cardiovascular system (1). Assessment of systolic time intervals, expressed as the ratio of the pre-ejection period (PEP) to the left ventricular ejection time (LVET), has proven its validity as an index of thyroid function (2 - 5). In overt hyperthyroidism PEP is shortened, while LVET is either unchanged or prolonged, resulting in a decreased ratio of PEP/LVET (2, 3, 5 - 7). More recently decreased PEP/LVET ratios have also been described both in subjects treated with excessive doses of L-thyroxine and in those with borderline thyrotoxicosis during antithyroid treatment of hyperthyroidism $(5,8-11)$. These reports refer to altered cardiodynamic function in subclinical thyrotoxic subjects under treated conditions. Data on cardiodynamic performance in endogenous subclinical hyperthyroidism, however, are scanty. We therefore conducted a cross-sectional study comparing PEP/LVET ratios and heart rates in women with untreated subclinical hyperthyroidism associated with multinodular goitre to data obtained in euthyroid women with multinodular goitres.

\section{SUBJECTS AND METHODS}

In a pilot study in 20 healthy females we have found a mean PEP/LVET ratio of 0.287 (range $0.233-0.317$ ). From this range and an expected difference in the PEP/LVET ratio of $0.035(5,9)$ we estimated that a sample size of 27 subjects in each group would be required for our study ( $\alpha$ error $=0.05, \beta$ error $=0.20$ ). The study subjects and controls were consecutively recruted from women attending the out-patient Clinic because of analysis of nodular goitre. The study group consisted of 27 women, aged between 28 and 75 years, with untreated multinodular goitre and subclinical hyperthyroidism. The control group consisted of 27 women, aged between 29 and 65 years, with untreated euthyroid multinodular goitre. Informed consent of the subjects and approval by the hospitals ethical committee were obtained. The existence of multinodular goitre was substantiated by ${ }^{99 \mathrm{~m}} \mathrm{Tc}$ scanning. Subclinical hyperthyroidism was defined as suppressed serum TSH levels (TSH $<0.1 \mathrm{mU} / 1$ ), in combination with normal (7.7 - $23.2 \mathrm{pmol} / \mathrm{l})$ serum free T4 (FT4) and normal (1.5 - $3.5 \mathrm{nmol} / \mathrm{l})$ total T3 values, according to the previously observed very high predictive value of the basal TSH-value for the outcome of the TRH-test (12). Total T3 was only determined when TSH was below $0.1 \mathrm{mU} / 1$ to exclude "T3-thyrotoxicosis". Subjects who had been treated for their thyroid disease, or with known cardiac disease (including disturbance in cardiac rhythm and the use of cardiovascular 
drugs) were excluded from the study.TSH was determined by an immunoradiometric assay (CIS, France). The intra-assay variations at TSH concentrations of 0.8 and $2.1 \mathrm{mU} / \mathrm{l}$ were $7.3 \%$ and $3.9 \%$, respectively. Inter-assay variations at TSH concentrations of 0.4 and $2.2 \mathrm{mU} / \mathrm{l}$ were $8.0 \%$ and $6.5 \%$ respectively. The detection limit of the TSH-assay was $0.02 \mathrm{mU} / \mathrm{l}$. Serum FT4 was determined by the SPAC-FT4 fraction test (Byk-Sangtec Diagnostica, Germany). The intra- and inter-assay variations in the normal range (7.7 - 23.2 $\mathrm{pmol} / 1$ ) were $6.7 \%$ and $7.4 \%$, respectively. Serum total $\mathrm{T} 3$ was determined by a radio-immunoassay method (Euro/DPC, Great Britain). The intra- and interassay variation in the normal range $(1.5-3.5 \mathrm{nmol} / \mathrm{l})$ were $2,5 \%$ and $2,7 \%$, respectively.

Systolic time intervals were measured, under stable temperature conditions with subjects in supine position after a 15 minutes period of rest, from simultaneous electrocardiographic and M-mode echocardiographic tracings obtained from a two-dimensional echocardiogram (Toshiba, SSH-160A) at a paper tracing speed of $100 \mathrm{~mm} / \mathrm{sec}$. PEP was the period from the initiation of the q-wave on the simultaneous ECG-tracing to aortic valve opening. LVET was the time between aortic valve opening and closure. All PEP/LVET results represent the mean values obtained from systolic time interval measurements in 3 cardiac cycles. Corrections for variations in heart rate were calculated according to Weissler's equation (13) to obtain PEPc/LVETc. Resting heart rates were recorded during these investigations. All cardiac measurements were performed by one of us (HD) without knowledge of the subjects thyroid function. The intra-observer variation of this method was $2.13 \%$.

Differences between groups were tested with unpaired Student's $t$ test or Mann Whitney's U test when appropriate. Correlations were analysed with Pearson's linear regression analysis. P-values below 0.05 were considered statistically significant.

\section{RESULTS}

Data on the thyroid function parameters are summarized in table 1. Median FT4 in the subclinical hyperthyroid subjects was significantly higher than in the euthyroid subjects, although all individual values were within the normal range (table 1). The subclinical hyperthyroid subjects had a significantly higher mean resting heart rate than the euthyroid controls (table 2). No significant difference was found between either mean PEP/LVET ratios or mean PEPc/LVETc ratios in the two groups (table 2). Individual values of PEP/LVET ratios and heart rate are depicted in figure 1. There was no significant correlation between thyroid 
Table 1

Thyroid function parameters in 27 subjects with euthyroid goitre (EG) and in 27 subjects with subclinical hyperthyroid goitre (SHG).

\begin{tabular}{llll}
\hline VARIABLE & EG & SHG & P \\
\hline TSH $(\mathrm{mU} / \mathrm{l})$ & $0.76(0.1-2.5)$ & $<0.1$ & \\
Total T3 (nmol/l) & & $2.6(1.9-3.5)$ & \\
FT4 (pmol/l) & $12.2(9.3-18.3)$ & $16.3(10-23.0)$ & 0.0002 \\
\hline
\end{tabular}

Data are expressed as median (range) values.

Table 2

Cardiac performance in 27 subjects with euthyroid goitre (EG) and in 27 subjects with subclinical hyperthyroid goitre (SHG).

\begin{tabular}{llll}
\hline VARIABLE & EG & SHG & P \\
\hline Heart rate(beats/min) & $80.0 \pm 14.4$ & $89.7 \pm 12.9$ & 0.0121 \\
PEP/LVET ratio & $0.281 \pm 0.048$ & $0.266 \pm 0.049$ & 0.25 \\
PEPc/LVETc ratio & $0.271 \pm 0.032$ & $0.259 \pm 0.032$ & 0.22 \\
\hline
\end{tabular}

Data are expressed as means $( \pm S D)$.

function parameters and systolic time intervals or heart rate, either in the study group or in the controls, although a non-significant tendency to higher heart rates at increasing serum FT4 values was documented in the subclinical hyperthyroid subjects $(r=0.37, P=0.06)$.

\section{DISCUSSION}

Systolic time intervals are reported to follow changes in thyroid function closely $(4,8,11)$. Institution of thyroid replacement therapy in hypothyroidism is followed by a decrease in PEP and an increase in LVET (4). Overtreatment of hypothyroid patients with L-thyroxine is common as indicated by slightly elevated thyroid hormone levels and suppressed TSH in many patients substituted with thyroid hormones $(5,10,14,15)$. In this medically induced borderline thyrotoxicosis significantly decreased PEP/LVET ratios are described $(5,9,10)$. Even subjects treated with L-thyroxine who combine suppressed TSH levels with normal thyroid hormone levels may have shortened 


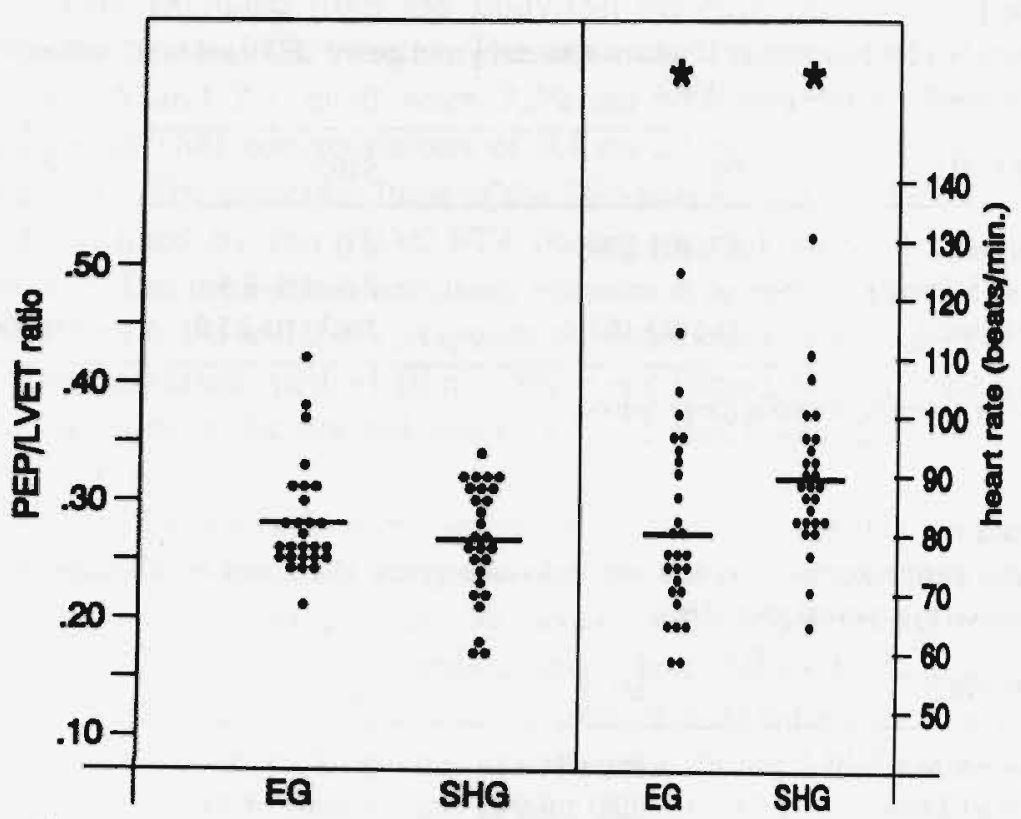

Figure 1

Individual data of PEP/LVET and heart rate in subjects with euthyroid goitre (EG) and in subjects with subclinical hyper-thyroid goitre (SHG). ${ }^{*} p=0.0121$

systolic time intervals (5). In our study of untreated women with multinodular goitre, however, we could not detect a significant difference in mean PEP/LVET ratio between subclinical hyperthyroid and euthyroid women, although there was a tendency to lower values in the former. Corrections for heart rate did not influence these results significantly. A possible explanation for the discrepancy between our results and those reported in subjects treated with L-thyroxine could be found in the consequences of the tightly individually tuned thyroid-pituitary feedback. Normally individual serum FT4 is restricted constantly within a narrow range, which is much smaller than indicated by the reference range for FT4 in the normal population. There seems to be an unique individual TSH setpoint relative to FT4 levels (16). Once FT4 exceeds the upper individual limit TSH becomes suppressed. Endogenous subclinical hyperthyroidism is a graded condition (17). The small difference in mean FT4 between the subclinical hyperthyroid subjects and the control subjects in our study suggests that a substantial proportion of the study group was in the very 
early stage of subclinical hyperthyroidism. Possibly the change in thyroid function in these subjects was more subtle than in those treated with $\mathrm{L}$ thyroxine, as reported in the studies mentioned before $(5,9,10)$.

In contrast to the lack of a significant difference in mean PEP/LVET ratio between the two groups, mean heart rate was significantly higher in the subjects with subclinical hyperthyroidism than in the euthyroid goitre subjects. Absolute values of heart rate were rather high, with frank sinus tachycardia occurring in both groups, suggesting psychological stress during the investigations. It seems unlikely, however, that this would have biased the results, because both groups were tested under the same conditions. Bell et al. (18) have previously described that L-thyroxine induced subclinical thyrotoxicosis affects heart rate more during sleep than at day-time. Boutin et al. (19) have found mean heart rate in endogenous subclinical hyperthyroid subjects half-way between that in euthyroid and hyperthyroid controls. Dosis reduction of L-thyroxine replacement therapy to the extent of which TSH irresponsiveness to TRH is restored, is accompanied by a fall in heart rate (15). It is likely that the increase in heart rate due to the slight thyroid hormone excess in endogenous subclinical hyperthyroidism is mediated by both direct and indirect effects. One of the earliest cardiovascular effects of thyrotoxicosis is a decrease in peripheral resistance. By reflex this could induce a cathecholamine mediated increase in cardiac output $(1,20)$. On the other hand, thyroid hormones directly increase the intrinsic activity of the sinus node (21).

In a recent study it has been shown that the severity of thyrotoxic symptoms does not correlate with thyroid hormone levels in overt hyperthyroidism, at least in Graves disease (22). In our study in multinodular goitre the increase in heart rate tended to parallel the serum FT4 levels in the subjects with subclinical hyperthyroidism, but the correlation between these parameters reached no statistical significance.

Suppression of the thyroid-pituitary axis may influence other organ systems as well as the cardiovascular system. In particular decreased bone density has been reported in subjects treated with suppressive doses of $L$-thyroxine $(23,24)$. We have recently described that also in women with untreated endogenous subclinical hyperthyroidism bone density is reduced (25). This, and the findings in the present study indicate that subjects with spontaneous suppressed TSH may have subtle symptoms of hyperthyroidism, although serum thyroid hormone levels are within the normal range. Moreover, these subjects seem to be at risk for developing atrial fibrilliation $(26,27)$. The cumulating evidence that subclinical hyperthyroidism may have harmful effects on target tissues advocates for thyrostatic treatment of this condition. The benificial effect of such a treatment, however, remains to be established. 
1. Klein I. Thyroid hormone and the cardiovascular system. Am J Med 1990; 88: 631 - 637.

2. Amidi M, Leon D F, de Groot W J, Kroetz F W, Leonard J J. Effect of thyroid state on myocardial contractility and ventricular ejection rate in man. Circulation 1968; 38: 229 . 239.

3. Parisi A F, Hamilton B P. Thomas C N, Mazzaferri E L. The short cardiac pre-ejection period. An index to thyrotoxicosis. Circulation 1974; 49:900 - 904.

4. Crowley W F Jr, Ridgway E C, Bough E W, Francis G S, Davids G H, Kourides I A, Myers G S, Maloof F. Noninvasive evaluation of cardiac function in hypothyroidism. N Engl J Med 1977; 296: 1 - 6.

5. Tseng K H, Walfish P G, Persaud J A, Gilbert B W. Concurrent aortic and mitral valve echocardiography permits measurement of systolic time intervals as an index of peripheral tissue thyroid function status. J Clin Endocrinol Metab 1989; 69: 633 - 638.

6. Burckhardt D, Staub J J, Kraenzlin M, Raeder E, Engel U, Cloppenburg P. The Systolic time intervals in thyroid dysfunction. Am Heart J 1978; 95: 187 - 196.

7. Lien $\mathrm{E}$, Aanderud S. Systolic time intervals in the evaluation of thyroid dysfunction. Acta Med Scand 1982; $211: 265$ - 268.

8. Jeric M, Banovac K, Baric L J, Sekso M. Estimation of systolic time intervals and timing of arterial sounds in hyperthyroidism during antithyroid medication. Acta Endocrinol 1982; $99: 50$ - 55 .

9. Jennings P E, O'Malley B P, Griffin K E, Northover B Rosenthal F D. Relevance of increased serum thyroxine concentrations associated with normal serum triiodothyronine values in hypothyroid patients receiving thyroxine: a case for "tissue thyrotoxicosis". B M J 1984; 289: 1645 - 1647.

10. Banovac K, Papic M, Bilsker, Zakarija M, McKenzie J M. Evidence of hyperthyroidism in apparently euthyroid patients treated with levothyroxine. Arch Intern Med 1989; 149: $809-812$.

11. Price D E, O'Malley B P, Northover B, Rosenthal F D. Changes in circulating thyroid hormone levels and systolic time intervals in acute hypothyroidism. Clin Endocrinol 1991; 35: $67-69$.

12. Mudde A H, Bastiaanse A J, Jonkers H. TSH-IRMA als eerste diagnosticum bij vermoeden van hyperthyreodie. Ned Tijdschr Geneeskd 1987; 131: 2364 - 2368.

13. Weissler A M, Harris W S, Schoenfeld C D. Systolic time intervals in heart failure in man. Circulation 1968; 2: 149 - 159.

14. Ross D S, Ardisson L J, Meskell M. Measurement of thyrotropin in clinical and subclinical hyperthyroidism using a new chemiluminescent assay. J Clin Endocrinol Metab 1989; 69: $684-688$.

15. Grund F M, Niewoehner C B. Hyperthyroxinemia in patients receiving thyroid replacement therapy. Arch Int Med 1989; 149: 921 - 924.

16. Nicoloff J T, Spencer C A. The use and misuse of the sensitive thyrotropin assays. J Clin Endocrinol Metab 1990; 71: 553 - 558.

17. Gemsenjäger E, Girard J. Preclinical hyperthyroidism - a graded condition. Acta Endocrinol 1983; 102: $521-526$. 
18. Bell G M, Sawers J S A, Forfar J C, Doig A, Toft A D. The effect of minor increments in plasma thyroxine on heart rate and urinary sodium excretion. Clin Endocrinol 1983; 18: $511-516$.

19. Boutin J M, Matte R, D'Amour P, Gilbert F, Havrankova J, Bélanger R, Chartrand R, Zakarija M. Characteristics of patients with normal T3 and T4 and a low response to TRH. Clin Endocrinol 1986; 25: 579-588.

20. TheilenEO, Wilson WR. Haemodynamic effects of peripheral vasoconstriction in normal and thyrotoxic subjects. J Appl Physiol 1967; 22: 207 - 210.

21. Valcavi R, Menozzi C, Roti E, Zini M, Lolli G, Roti S, Guiducci U, Portioli I. Sinus node function in hyperthyroid patients. J Clin Endocrinol Metab 1992: 75: 239 - 242.

22. Trzepacz P T, Klein I, Roberts M, Greenhouse J, Levey G S. Graves disease: an analysis of thyroid hormone levels and hyperthyroid signs and symptoms. Am J Med 1989; 87: $558-561$.

23. Ross DS, Neer RM, Ridgway EC, Daniels GH. Subclinical hyperthyroidism and reduced bone density as a possible result of prolonged suppression of the pituitary-thyroid axis with L-thyroxine. Am J Med 1987; 82: 1167-1172.

24. Diamond T, Nery L, Hales I. A therapeutic dilemma: Suppressive doses of thyroxine significantly reduce bone mineral measurements in both premenopausal and postmenopausal women with thyroid carcinoma. J Clin Endocrinol Metab 1991; 72: 1184 -1188 .

25. Mudde A H, Reijnders F J L, Nieuwenhuijzen Kruseman A C. Peripheral bone density in women with untreated multinodular goitre. Clin Endocrinol 1991; 37: 35 - 39.

26. Forfar J C, Miller H C, Toft A D. Occult thyrotoxicosis: a correctable cause of "idiopathic atrial fibrillation". Am J Cardiol 1979; 44: 9 - 12.

27. Tenerz $\AA$, Forberg $R$, Jansson $R$. Is a more active attitude warranted in patients with subclinical thyrotoxicosis? J Int Med 1990; 228: 229 - 233. 


\section{Chapter 7}

\section{BONE METABOLISM DURING THYROSTATIC TREATMENT OF SUBCLINICAL HYPERTHYROIDISM.}

A PRELIMINARY REPORT 


\section{INTRODUCTION}

Several reports have indicated that in subclinical thyrotoxicosis due to $\mathrm{L}$ thyroxine treatment bone turnover is increased and bone density is decreased $(1,2)$. Endogenous subclinical hyperthyroidism may also have adverse effects on bone $(3,4)$. It is not clear, however, whether the changes in bone metabolism are reversible if euthyroidism is restored. To evaluate this possibility we treated 8 subjects with endogenous subclinical hyperthyroid multinodular goitre for a period up to 24 months and followed bone turnover parameters and bone density measurements. To avoid the bias of menopause on parameters of bone metabolism only postmenopausal women were included for treatment, considering that this cathegory of subjects is at particular risk for developing osteoporosis. For comparison 8 untreated postmenopausal women with subclinical hyperthyroidism were followed as well. In this Chapter perliminary results of this still ongoing study are presented.

\section{SUBJECTS AND METHODS}

Sixteen postmenopausal women with subclinical hyperthyroid multinodular goitre were selected for this study. Subclinical hyperthyroidism was defined as a suppressed serum TSH concentration (TSH $<0.1 \mathrm{mU} /$ ) and FT4 and total T3 concentrations within the reference range. Eight out of these 16 subjects were randomly assigned to receive thyrostatic treatment. All subjects gave written informed consent and the study protocol was approved by the hospital's Ethical Committee. Treatment consisted of methimazole at a starting dose of $10 \mathrm{mg}$ three times daily. The dose was initially adjusted 6 and 12 weeks after the onset of treatment and at 3 months intervals thereafter to reach a serum TSH level between 1 and $3.5 \mathrm{mU} / 1$. The 8 untreated women were followed at 3 months intervals. The follow-up period was 24 months. In the treatment group followup was incomplete in 3 subjects at 9,15 and 21 months, respectively. In the control group follow-up was incomplete in 2 subjects at 24 months. There were no significant differences between the treatment and the control group. Details about the subjects are summarized in table 1.

Intra- and interassay variations of serum TSH, determined by a "second generation" immuno-radiometric assay (International CIS, France), ranged from 3.9 to $10.0 \%$ in the normal and low (TSH $<0.1 \mathrm{mU} /$ ) range, respectively. Serum FT4, determined by the "SPAC-FT4-fraction test" (Byk-Sangtec Diagnostica, Germany), had intra- and inter-assay variations in the normal range (7.7 $-23.2 \mathrm{pmol} / \mathrm{l}$ ) of $6.7 \%$ and $8.7 \%$, respectively. Serum total $\mathrm{T} 3$, determined by a 
Table 1

Clinical characteristics of 16 postmenopausal women with subclinical hyperthyroid multinodular goitre. Eight of these were treated with methimazole to reach euthyroidism.

\begin{tabular}{|c|c|c|}
\hline & $\begin{array}{l}\text { Treatment group } \\
(\mathrm{n}=8)\end{array}$ & $\begin{array}{l}\text { Control group } \\
(n=8)\end{array}$ \\
\hline Age, years & $61.6 \pm 2.7$ & $62.6 \pm 2.4$ \\
\hline FT4, pmol// & $16.7 \pm 0.4$ & $14.8 \pm 1.2$ \\
\hline $\mathrm{T} 3, \mathrm{nmol} / \mathrm{h}$ & $2.6 \pm 0.2$ & $2.7 \pm 0.1$ \\
\hline osteocalcin, $\mu \mathrm{g} / \mathrm{l}$ & $13.2 \pm 1.1$ & $13.6 \pm 0.7$ \\
\hline $\begin{array}{l}\text { alkaline phosphatase, } \mathrm{U} / \mathrm{l} \\
\text { urinary excretion of }\end{array}$ & $72 \pm 5$ & $80 \pm 4$ \\
\hline - hydroxyproline/creatinine, $\mu \mathrm{mol} / \mathrm{mmol}$ & $22.8 \pm 2.4$ & $20.4 \pm 2.4$ \\
\hline $\begin{array}{l}\text { - calcium } / \mathrm{creatinine}, \mathrm{mmol} / \mathrm{mmol} \\
\text { bone density, } \mathrm{U} / \mathrm{cm}^{2}\end{array}$ & $0.58 \pm 0.04$ & $0.49 \pm 0.07$ \\
\hline - distal & $0.74 \pm 0.04$ & $0.73 \pm 0.08$ \\
\hline - proximal & $1.05 \pm 0.04$ & $0.99 \pm 0.10$ \\
\hline
\end{tabular}

Data are expressed as mean values $\pm \mathrm{SEM}$.

double antibody radio-immuno assay (Euro/DPC. Great Britain), had intra- and inter-assay variations in the normal range $(1.5-3.5 \mathrm{nmol} / \mathrm{l})$ of $2.5 \%$ and $2.7 \%$, respectively. Intra- and inter-assay variations of serum osteocalcin, determined by a bovine radio-immuno assay (International CIS, France), ranged from $1.7 \%$ to $6.7 \%$,in the normal range $(3.5-16.2 \mathrm{ug} / 1)$. Total serum alkaline phosphatase was determined by an auto-analyzer (Hitachi 717, Boehringer Mannheim) using a routine calorimetric method. Urinary excretions of hydroxyproline and calcium were calculated as the means of two 24-hours collections, related to creatinine excretion, on a gelatine-restricted diet starting 2 days before the urine collections. Hydroxyproline was determined colorimetrically at lambda $=560$ nm (Hypronosticon, Organon Technika) after hydrolysis during 16 hours at $100^{\circ} \mathrm{C}$ and oxydation. The analytical coefficient of variation of hydroxyproline determinations was $13.4 \%$ in the normal range. Urinary calcium was determined colorimetrically at lambda $=546 \mathrm{~nm}$ (Hitachi 717, Boehringer Mannheim). Bone density was measured in the non-dominant forearm by single photon absorptiometry (Nuclear Data ND 1100 A, USA). Results are expressed in arbitrary units per square centimeter $\left(\mathrm{U} / \mathrm{cm}^{2}\right)$. The coefficients of variation of repeated measurements for the distal and proximal forearm bone density were $3.1 \%$ and $1.9 \%$, respectively. 
The results are presented as means \pm SEM of absolute values or percentages of base-line values. Differences between means were tested with ANOVA. The changes of the parameters against time were analyzed with the best fitting regression analysis. An assigned significance level of 0.05 was used.

\section{RESULTS}

\section{Treatment group}

In the group of treated subjects a significant $(P<0.01)$ decline in mean FT4 was observed onwards from 6 weeks after the onset with methimazole therapy (fig. 1). The mean TSH-value increased to the objected level, although some individual values rose to the hypothyroid range (fig.1). Three months after the onset of methimazole therapy 3 subjects still had serum TSH values $<0.1 \mathrm{mU} /$, which increased to the objected range thereafter. Urinary hydroxyproline excretion declined during treatment with methimazole. The best fitting correlation between the percentage of base-line value of urinary hydroxyproline/creatinine ratio against time since onset of treatment was obtained with hyperbolic regression analysis $(y=1 /(0.0104+0.0004 x), r=0.36 ; P<0.001)$ (fig. 2). Neither the serum osteocalcin concentration, nor the serum alkaline phosphatase concentration changed significantly during the observation period. Data of percentages of base-line osteocalcin values are depicted in figure 2 .

During treatment osteocalcin and alkaline phosphatase were significantly correlated (\% osteocalcin $=46.42+0.55$ (\% alkaline phosphatase), $\mathrm{r}=0.47 ; \mathrm{P}$ $<0.01)$. Urinary calcium excretion did not change during the treatment period (data not shown). Both distal and proximal forearm bone density remained stable during the observation period (figs. 3 and 4).

\section{Control group}

In the untreated subjects FT4 remained stable throughout the observation period (fig. 1). In none of the subjects a progression to overt hyperthyroidism was observed. All serum TSH values remained $<0.1 \mathrm{mU} / \mathrm{l}$ during the entire observation period. Serum osteocalcin and alkaline phosphatase and the urinary excretions of hydroxyproline and calcium did not change (data not shown). There was a time correlated negative trend in bone density, expressed as percentage from base-line value, which was significant for the distal site ( $\mathrm{y}=$ 


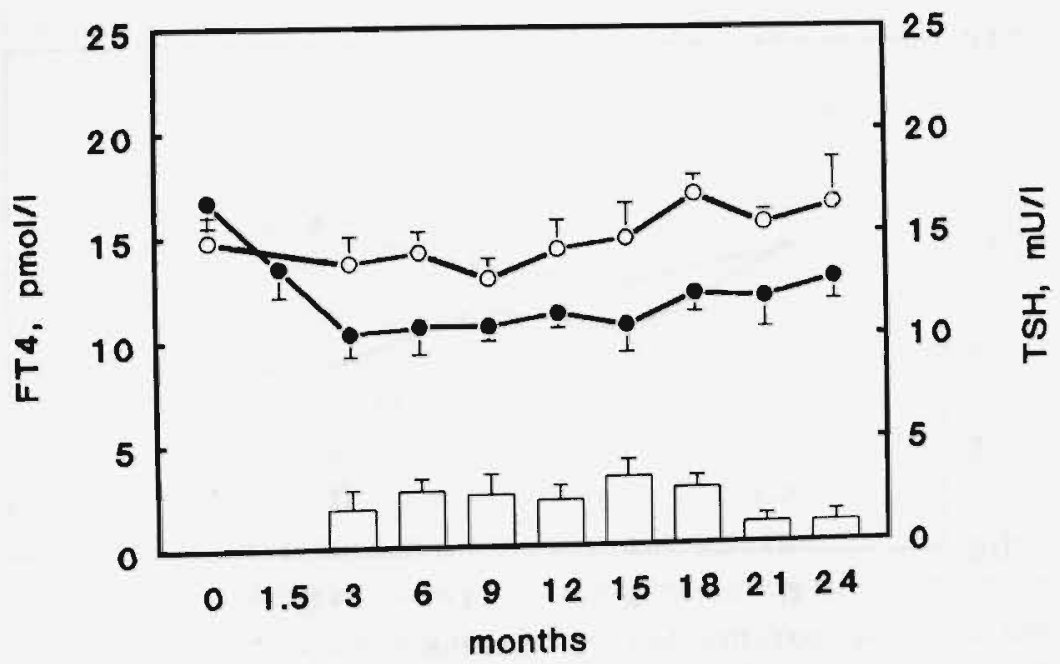

Figure 1

Mean $( \pm$ SEM) serum FT4 and TSH values in postmenopausal women with subclinical hyperthyroidism during treatment with methimazole (FT4: solid circles; TSH: bars) or no treatment (FT4: open circles). All FT4 values in treated women are different frome base-line $(\mathrm{P}<0.01)$.

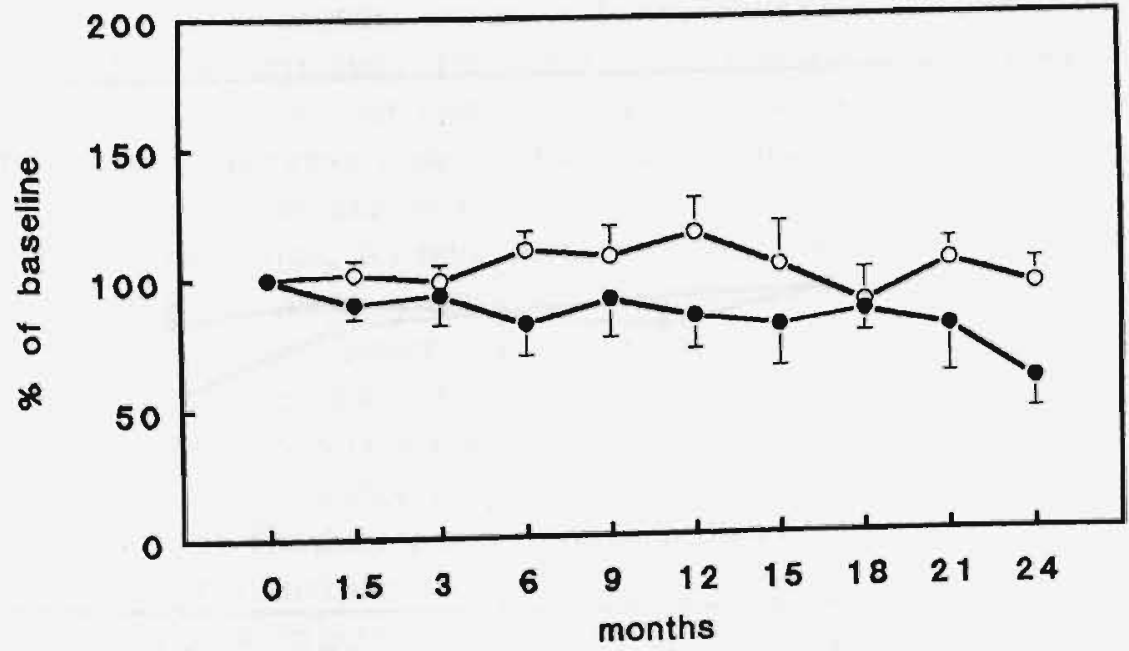

Figure 2

Mean ( \pm SEM) percentage of base-line concentration of serum osteocalcin (open circles) and 24 hours-urinary hydroxyproline/creatinine ratio (solid circles) in postmenopausal women with subclinical hyperthyroidism during treatment with methimazole. The regression of 24 hoursurinary hydroxyproline/creatinine ratio against time is significant $(y=1 /(0.0104+0.0004 x), r$ $=0.36 ; \mathrm{P}<0.001$ ). 


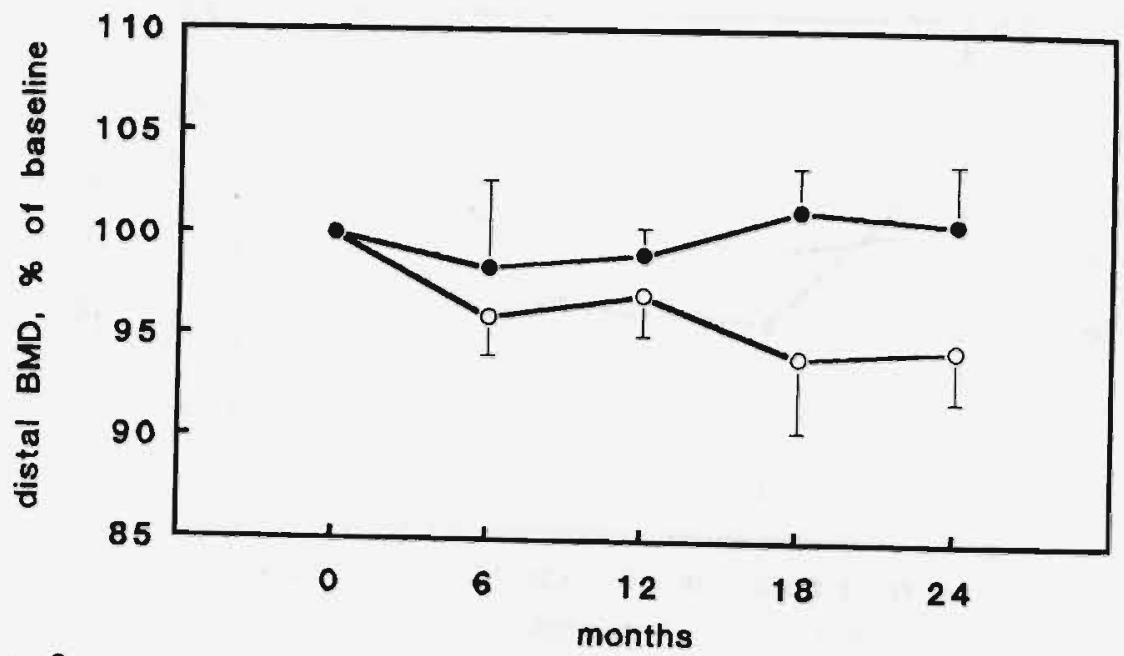

Figure 3

Mean ( \pm SEM) percentage of base-line bone density in distal forearm in postmenopausal women with subclinical hyperthyroidism during treatment with methimazole (solid circles) or no treatment (open circles). The regression of distal bone density against time in the untreated subjects (open circles) is significant $(y=1 /(0.0101+0.0000026 x), r=0.34 ; P<0.05)$.

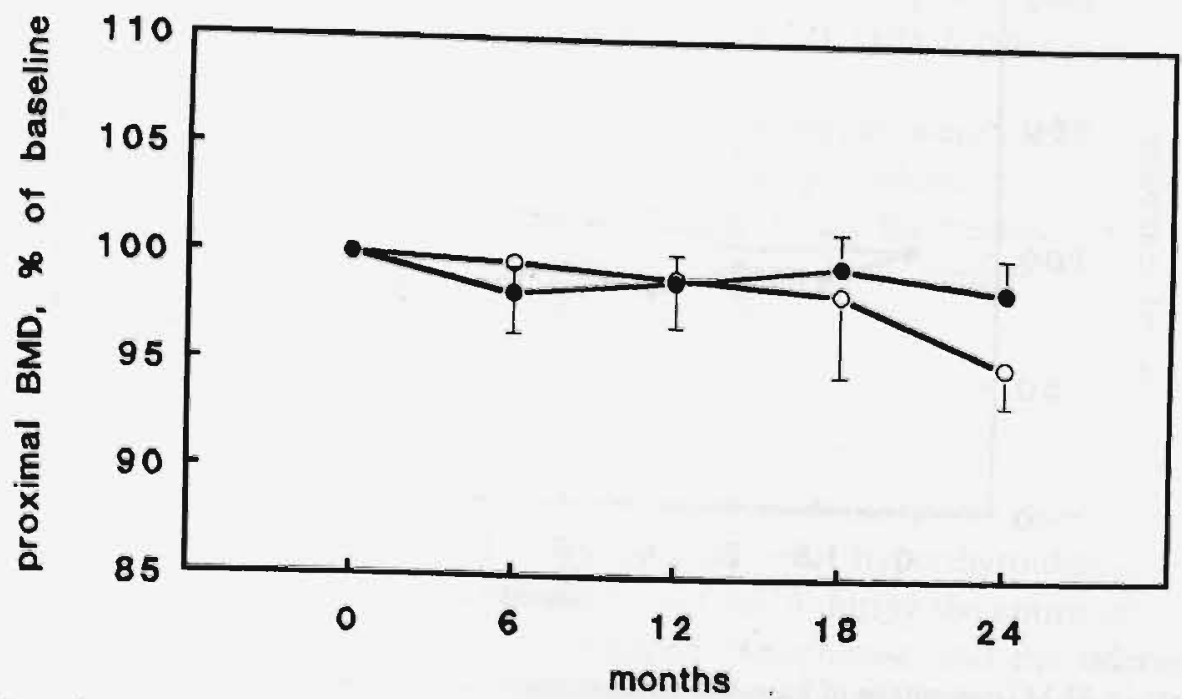

Figure 4

Mean $( \pm$ SEM) percentage of base-line bone density in proximal forearm in postmenopausal 


\section{DISCUSSION}

The cumulating evidence that exogenous subclinical thyrotoxicosis exerts undesirable effects on bone has forced monitoring of thyroid replacement therapy within a strict euthyroid range $(5,6)$. It is not known, however, whether thyrostatic treatment of spontaneous subclinical hyperthyroidism is benificial. Although the number of subjects in this study was too small to observe between-group differences, some interesting longitudinal observations have emerged from the available data.

Information on bone turnover during thyrostatic treatment is scanty. Some authors have described a rapid normalization of elevated osteocalcin levels in thyroid hormone excess when euthyroidism was restored $(7,8)$. In a recent study in a small group of subjects, however, a discrepancy was observed between a rapid decline in urinary excretion rates of pyridinium cross-links and unchanged elevated serum osteocalcin levels during the first 3 months after radioiodine therapy for hyperthyroidism (9). Another study, in children, has indicated that serum osteocalcin levels may remain elevated up to a year after the onset of thyrostatic treatment (10). Earlier observations on serum alkaline phosphatase levels in hyperthyroidism have shown that thyrostatic treatment induces an initial increase followed by a slow decline in serum levels of alkaline phosphatase (11 - 13). In contrast, urinary hydroxyproline excretion rapidly declines after institution of thyrostatic treatment $(11,12)$. Our present data in subclinical hyperthyroidism show that urinary hydroxyproline excretion was inversely correlated with time since onset of thyrostatic treatment $(P<0.05)$, while both serum osteocalcin and alkaline phosphatase levels remained unchanged during the observation period. As bone turnover follows an orderly chronological organisation of activation, resorption and formation, it is well recognized that it generally takes several months for therapeutic interventions to normalize the rate of bone tumover $(14-16)$. Although the frequency of bone remodeling cycles in thyroid excess is increased (16), in older adults it may take a full year for the remodeling balance to reach a new equilibrium after a therapeutic intervention (15). The discrepancy between the lack of change in the parameters of bone formation and the decline in urinary hydroxyproline excretion may indicate a dissociation between bone formation and bone resorption in favour of the former.

As in the untreated state (Chapter 5), serum osteocalcin and alkaline phosphatase concentrations were correlated during thyrostatic treatment.

In contrast to observations during treatment of overt hyperthyroidism $(11,12$, 17) urinary calcium excretion did not change during treatment of subclinical hyperthyroidism with methimazole in the present study. This may be due to an 
interfering effect of thyrostatic treatment on serum PTH levels, resulting in an altered urinary calcium excretion (18). This possibility was, however, not further explored in this study.

In the treated subjects no change in forearm bone density was noted during the observation period. The expected physiological loss of bone in these postmenopausal women seemed to be compensated by an unchanged bone formation activity in the face of a declined bone resorption rate. In contrast, the untreated group showed a steady decline in forearm bone density, which was significant for the distal site. Since the rate of physiological bone loss in postmenopausal women is highly dependent on years since menopause (19-21), we cannot indicate if the observed decline in bone density in these subjects was supraphysiological, as no data on bone loss in age matched euthyroid controls were available.

In conclusion thyrostatic treatment with methimazole in postmenopausal subclinical hyperthyroid women with multinodular goitre results in a decline in osteoclastic bone resorption with unaltered bone formation, as was judged by a significant decline in urinary hydroxyproline excretion, while the parameters of bone formation did not change. The benificial effect of thyrostatic treatment on bone was illustrated by a stable bone density during the treatment period, despite the postmenopausal status of the treated subjects. In contrast, a gradual loss of bone density was observed in untreated postmenopausal women with subclinical hyperthyroidism. The question whether bone density during thyrostatic treatment will be stabalized at a normal level for age and menopausal status in the long-run needs further investigation. 


\section{REFERENCES}

1. Ross D.S., Neer R.M., Ridgway E.C., Daniels G.H. Subclinical hyperthyroidism and reduced bone density as a possible result of prolonged suppression of the pituitary-thyroid axis with L-thyroxine. Am J Med, 1987; 82: 1167-1170.

2. Diamond T., Nery L., Hales I. A therapeutic dilemma: suppressive doses of thyroxine significantly reduce bone mineral measurements in both premenopausal and postmenopausal women with thyroid carcinoma. J Clin Endocrinol Metab, 1991; 72: 1184-1188.

3. Faber J., Perrild H., Johansen J.S. Bone Gla protein and sex hormone-binding globulin in nontoxic goitre: parameters for metabolic status at the tissue level. J Clin Endocrinol Metab, 1990; 70: 49-55.

4. Mudde A.H., Reijnders F.J.L., A.C. Nieuwenhuijzen Kruseman. Peripheral bone density in women with untreated multinodular goitre. Clin Endocrinol, 1992; 37: 35-39.

5. Burman K.D. Is long-term levothyroxine therapy safe? Arch Intern Med, 1990; 150: 2010-2013.

6. Ross D.S. Monitoring L-thyroxine therapy: lessons from the effects of L-thyroxine on bone density. Am J Med, 1991; 91: 1-4.

7. Garrel D.R., Delmas P.D., Malaval L., Toumiaire J. Serum bone Gla protein: a marker of bone tumover in hyperthyroidism. J Clin Endocrinol Metab, 1986; 62: 1052-1055.

8. Faber J., Perrild H., Johansen J.S. Serum bone Gla protein (BGP) during treatment of hyperthyroidism and hypothyroidism. Horm Metab Res, 1991; 23: 135-138.

9. Macleod J.M., McHardy K.C., Harvey R.D., et al. The early effects of radioidine therapy for hyperthyroidism on biochemical indices of bone turnover. Clin Endocrinol, 1993; 38: $49-53$.

10. Saggese G., Bertelloni S., Baroncelli G.I. Bone mineralization and calciotropic hormones in children with hyperthyroidism. Effects of methimazole therapy. J Endocrinol Invest, 1990; 13: 587-592.

11. Siersbaek-Nielsen K., Skovsted L., Mølholm Hansen J., Kristensen M., Korsgaard Christensen L. Hydroxyproline excretion in the urine and calcium metabolism during long-term treatment of thyrotoxicosis with propylthiouracil. Acta Med Scan, 1971; 189: 485-488.

12. Mosekilde L., Christensen S.M., Melsen F., Schwartz Sørensen N. Effects of antithyroid treatment on calcium-phosphorus metabolism in hyperthyroidism. I: Chemical quantities in serum and urine. Acta Endocrinol, 1978; 87: 743-750.

13. Cooper D.S., Kaplan M.M., Ridgway E.Ch., Maloof F., Daniels G.H. Alkaline phosphatase isoenzyme patterns in hyperthyroidism. Ann Int Med, 1979; 90: 164-168.

14. Frost H.M. Tetracycline-based histological analysis of bone remodeling. Calcif Tiss Res, 1969; 3: 211-237.

15. Heany R.P. Thinking straight about calcium. New Eng J Med, 1993; 328: 503-505.

16. Eriksen E.P. Normal and pathological remodeling of human trabecular bone: three dimensional recontruction of the remodeling sequence in normals and in metabolic bone disease. Endocr. Rev., 1986; 7: 379-410.

17. Bijlsma J.W.J., Duursma S.A., Roelofs J.M.M., der Kinderen P.J. Thyroid function and bone turnover. Acta Endocrinol, 1983; 104: 42-49. 
18. Ross D.S., Nussbaum S.R. Reciprocal changes in parathyroid hormone and thyroid function after radioiodine treatment of hyperthyroidism. J Clin Endocrinol Metab, 1989b; 68: 1216-1219.

19. Nilas L., Borg J., Gotfredsen A., Christiansen C. Comparison of single- and dualphoton absorptiometry in postmenopausal bone mineral loss. J Nucl Med, 1985; 26: 1257-1262.

20. Nordin B.E., Need A.C., Chatterton B.E., Horowitz, Morris. The relative contributions of age and years since menopause to postmenopausal bone loss. JClin Endocrinol Metab, 1990; 70: 83-88.

21. Hui S.L., Wiske P.S., Norton J.A. Johnston C.C.Jr. A prospective study of change in bone mass with age in postmenopausal women. J Chron Dis, 1982; 35: 715-725. 
| Chapter 8

GENERAL DISCUSSION 


\subsection{INTRODUCTION}

Subclinical hyperthyroidism is defined as a TRH-resistant TSH suppression, together with normal serum levels of thyroid hormones (Gemsenjäger et al, 1976). Recently an increased frequency of nervous symptoms has been observed in subjects with subclinical hyperthyroidism (Schlote et al., 1992). This Chapter focuses on the somatic aspects of subclinical hyperthyroidism. The results of the surveys described in this thesis will be discussed in relation to the available data in the literature.

\subsection{TSH AND THYROID HORMONES}

The development of immuno-radiometric TSH assays has contributed to a better discrimination between hyperthyroidism and euthyroidism. In comparison with the traditional TSH-RIA's these and other socalled "second generation" TSH assays have a markedly improved sensitivity, which has made the determination of the serum concentration of TSH a first line thyroid function test, at least in an outpatient setting. In hospitalized patients, frequently suffering from other diseases, this strategy may be less effective, mainly because of varying results of TSH determinations obtained in "non-thyroidal illness" (Ehrmann et al., 1989, Nicoloff and Spencer, 1990, Surks et al., 1990, DeGroot and Mayer, 1992). As was shown in Chapter 2 hyperthyroidism is almost definitely excluded if the serum TSH concentration, measured by a "second generation" IRMA, is above $0.1 \mathrm{mU} / 1$. A suppressed TSH (TSH $<0.1 \mathrm{mU} / \mathrm{l}$ ) appeared to be highly predictive for a blunted response of TSH to TRH, which finding is consistent with data reported in the literature on this subject (Seth et al., 1984, Gibold et al., 1986, Wiersinga et al., 1986, Caldwell et al., 1987). Wiersinga et al. (1986), however, have shown that in some subjects with a subnormal response of TSH to TRH, basal serum TSH concentrations, measured by IRMA, may not be fully suppressed. The reverse, intact TSH response to TRH at basal serum TSH levels $<0.1 \mathrm{mU} /$, may also occur, as has been shown with a "third generation" TSH assay (Spencer et al., 1990). The sensitivity of the "third generation" TSH assays is about 10-fold increased in comparison with the "second generation" assays. It is likely that with these recently developed "third generation" TSH assays the discrimination between suppressed and TRH-responsive TSH values can be made even better than with the "second generation" TSH assays. This would probably result in a better demarcation between euthyroidism and thyroid autonomy (Spencer et al., 1990, Hashimoto et al., 1991). According to Bayes theorem, however, the predictive 
value of a suppressed TSH level for overt hyperthyroidism is dependent of the prevalence of thyrotoxicosis in the population, as can also be drawn from the data in Chapter 2 and has been shown by others (Hennemann et al., 1987).

In multinodular goitre a substantial number of subjects is discovered with suppressed serum TSH levels and values for serum thyroid hormone concentrations within the normal range. The question arises whether these subjects should be regarded as "underway" to hyperthyroidism (i.e."subclinical" hyperthyroid) or as overt thyrotoxic. Within one individual the level of serum thyroid hormones is kept stable throughout life, within a range that is much smaller than the reference range in the healthy population (Larsen, 1982, Nicoloff and Spencer, 1990, Gambert, 1991). A minor increase in the physiological serum thyroid hormone levels causes suppression of TSH secretion (Larsen et al., 1982, Spencer et al, 1990). There seems to be an interindividually different setpoint of thyroid hormone levels at which TSH secretion becomes suppressed (Spencer et al., 1990, Nicoloff and Spencer, 1990). The level of serum thyroid hormones in subclinical hyperthyroidism is discussed in several studies. In the present survey (Chapter 4 and 5) and in other studies (Emrich and Bähre, 1978, Berghout et al., 1990, Parle et al, 1992) women with multinodular goitre and suppressed TSH appeared to have a slightly higher level of serum FT4 than euthyroid women with goitre. This argues not only for interindividual differences of TSH-sensitivity for thyroid hormones, but also suggests that the "normal" reference range of FT4 is smaller than usually considered. This seems to be confirmed by the range of FT4 which we observed in healthy women (Chapter 3). Some authors have reported a slightly elevated mean serum T3 level in subjects with subclinical hyperthyroidism (Evered et al., 1974, Smeulers et al., 1977, Emrich and Bähre, 1978). This has not been confirmed, however, by others (Gemsenjäger and Girard, 1983, Berghout et al., 1990). Berghout et al. (1990) have described that subjects with multinodular goitre have slightly higher serum total $\mathrm{T} 3$ values within the normal range than euthyroid subjects without goitre, but they did not find a difference between those with normal and those with suppressed TSH levels.

In conclusion subjects with multinodular goitre and subclinical hyperthyroidism may have serum thyroid hormone concentrations within the reference range, which are inadequately high for their individual needs, as is indicated by suppressed serum TSH levels and a slightly elevated median serum FT4 concentration. 
Circulating levels of thyroid hormones do not universally reflect cellular concentrations as was shown in vitro in rats (Obregon et al., 1979, Van Doorn et al., 1985) and made plausible in human studies (Larsen et al., 1982). Local conversion of T4 to T3 differs widely between the various target organs of thyroid hormones (Van Doorn et al., 1985). There is a remarkable difference in local production of $\mathrm{T} 3$ between the hypothalamus and anterior pituitary gland, both of which are involved in the feedback with the thyroid gland, although in both systems the local conversion is much higher than in most peripheral tissues, as was shown in rats (Van Doorn et al., 1985). Physiologically, circulating T4 seems to be more important than T3 in the feedback system (Larsen et al., 1982, Spencer et al., 1990). It is not known whether the intracellular level of T3 in subjects with suppressed TSH and normal circulating thyroid hormone levels is increased. Some metabolic aspects, however, suggest that this might indeed be the case.

Serum levels of sex hormone binding globulin (SHBG), which is supposed to be a marker of tissue activity of thyroid hormones, are elevated both in endogenous subclinical hyperthyroid subjects and in subjects treated with suppressive doses of L-thyroxine (Faber et al., 1990a, Faber et al., 1990b, Giagulli and Vermeulen, 1992). Serum levels of SHBG correlate with serum TSH concentrations (Faber et al., 1990b, Jarløv et al., 1992).

Increased serum levels of $5 \alpha$-androstane- $3 \alpha, 17 \beta$-diolglucuronide have been documented in postmenopausal women with suppressed TSH and normal serum thyroid hormone levels, indicating an increased thyroid induced $5 \alpha$-reductase activity in the liver in subclinical hyperthyroidism (Giagulli and Vermeulen, 1992).

Recently a decreased mean total serum cholesterol level has been described in subjects with suppressed TSH and normal thyroid hormone levels. (Parle et al., 1992). Serum LDL cholesterol levels, however, appeared to be unchanged.

In conclusion these data indicate that some biochemical markers of peripheral thyroid hormone activity are increased in subclinical hyperthyroidism.

\subsection{BONE TURNOVER}

In this survey serum osteocalcin levels, a parameter of bone turnover, were studied in relation to subclinical hyperthyroidism. In healthy women serum osteocalcin levels appeared to vary with age, showing a decline in adult life, 
which reached a nadir in the fourth decade, followed by an increase around the age of 50 years (Chapter 3). Although there is some variance in the data concerning age related changes in serum osteocalcin the pattern that was found in this study was not essentially different from most of the reported data (Delmas et al., 1983, Epstein et al., 1984, Worsfold et al., 1988, Duda et al., 1988, Tarallo et al., 1990, Vanderschueren et al., 1990). From these -transversal- observations it appears that the serum osteocalcin level increases in the perimenopausal period. In one of the earliest reports on serum osteocalcin levels in healthy females, however, a negative correlation between serum osteocalcin values and age was observed (Price et al., 1980b). Since osteocalcin is a vitamin $\mathrm{K}$ dependent protein this discrepancy might be due to a difference in vitamine $\mathrm{K}$ levels in these subjects. Data on the vitamin $\mathrm{K}$ status, however, are not available in these reports. Knapen et al. (1989) have shown that serum osteocalcin levels in apparently healthy postmenopausal women increase to higher than premenopausal values only after vitamin $\mathrm{K}$ administration.

The available data concerning serum osteocalcin levels in subclinical thyrotoxicosis are largely derived from subjects treated with suppressive doses of L-thyroxine. These data are not unequivocally. The discrepancy in results between some of these studies is reviewed in Chapter 5. In endogenous subclinical hyperthyroidism information about osteocalcin levels is scanty. In the present survey, in a cross-sectional study in 77 women with multinodular goitre, higher levels of serum osteocalcin were found in those with suppressed TSH than in the euthyroid subjects (Chapter 5). Expression of the data as Z-scores revealed that the increase in osteocalcin levels in women with subclinical hyperthyroid multinodular goitre in comparison with euthyroid goitre subjects was not due to age (Chapter 5). These data are in agreement with those of Faber et al. (1990b), which also have indicated that serum osteocalcin is elevated in spontaneous subclinical hyperthyroidism. Like Faber et al. (1990b) and Ross et al. (1991c) no correlation between osteocalcin (expressed as Z-scores) and serum thyroid hormones in women with subclinical hyperthyroid multinodular goitre could be established, although positive correlations between both absolute and relative (as Z-scores) osteocalcin values and FT4 were observed when the data of the subclinical hyperthyroid and euthyroid goitre subjects were pooled.

Most of the clinical studies on osteocalcin up to now have been performed with heterologeous immuno-assays. The recently developed immuno-assays raised against human osteocalcin probably may offer a more reliable quantitation of bone formation than the bovine assay we have used in the present study (Kanzaki et al., 1992). 
Not only osteocalcin, but also the median concentration of serum alkaline phosphatase appeared to be higher in women with subclinical hyperthyroid multinodular goitre than in women with euthyroid goitre, although individual values were all within the normal range (Chapter 5). Beside these indications of increased osteoblastic function in subclinical hyperthyroidism, recently an increased osteoclastic activity in postmenopausal women during suppressive L-thyroxine treatment was substantiated by the demonstration of increased urinary excretion of pyridinium cross-links in these subjects (Harvey et al., 1991). These indications of increased parameters of both osteoblastic and osteoclastic activity in subclinical thyrotoxicosis suggest an increased activation frequency of bone remodeling units in this condition. In overt thyrotoxicosis a negative balance between bone formation and resorption is supposed (Meunier et al., 1972, Melsen and Mosekilde, 1977, Eriksen et al., 1985). It should be noticed, however, that the data of Eriksen et al. (1985) were based on extrapolation of the appositional growth curve. The actually measured maximal completed wall thickness in thyrotoxic trabecular bone in this particular study, however, was not different from normal. Nevertheless, even if there would not be an imbalance between bone formation and resorption in a state of mild thyroid hormone excess, the increased bone turnover rate in subclinical hyperthyroidism would still result in accelerated loss of bone, since there is a physiological imbalance between osteoblastic apposition and osteoclastic resorption in older adult women (Parfitt 1979, Parfitt 1986).

In conclusion the data obtained in women with endogenous subclinical hyperthyroid multinodular goitre point to an increased bone turnover rate in this condition. A combination of measurements of human osteocalcin with te newer, more sensitive and specific parameters of osteoclastic activity, like tartrate resistant acid phosphatase (Lau et al. 1987, Stepán et al., 1989, Kraenzlin et al., 1990 ) and pyridinium crosslinks (Delmas et al., 1991, Hassaet al., 1992, Uebelhart et al., 1992, Harvey et al., 1992) would possibly offer more insight in the extend to which bone turnover is increased in subclinical hyperthyroidism.

\subsection{BONE DENSITY}

Fracture risk scores and assessments of clinical and biochemical parameters of bone density have not a high predictive value for the occurrence of fractures (Elders et al., 1989, Van Hemert et al., 1990). In contrast, direct measurement of bone density, as performed with single photon absorptiometry, is a reliable method to predict fracture risk (Hui et al., 1988, Hui et al., 1989, Melton et al., 1990, Johnston et al., 1991). In Chapter 4 we have shown that women with 
multinodular goitre who expose a suppressed TSH in combination with normal serum thyroid hormone levels have decreased Z-scores of forearm bone density in comparison with euthyroid goitre women. No other reports on bone density in endogenous subclinical hyperthyroidism are available up to now.

Recently, several editorials in main clinical journals have addressed the possible adverse effects of oversubstitution of thyroid hormones on bone density (Perry III et al., 1986, Burman, 1990, Franklyn and Sheppard, 1990, Baran and Braverman, 1991, Toft, 1991, Ross, 1991a). This commotion was induced by many recent papers concerning photon-absorptiometric determinations of bone density, indicating bone loss due to subclinical thyrotoxicosis induced by L-thyroxine therapy. In one of the first of these reports 3 case histories of L-thyroxine treated postmenopausal women with fractures and histologically confirmed osteoporosis have been described (Fallon et al., 1983). Actually, these subjects were substituted in a mild thyrotoxic range. Additional reports -some of which are summerized here- in subjects on L-thyroxine treatment have indicated that substitution to a level at which TSH becomes suppressed, may be harmful to bone metabolism, despite serum thyroid hormones are within the normal range. Ross et al. (1987) have described a significant inverse correlation between forearm bone density and years of L-thyroxine treatment in premenopausal women. The mean serum level of thyroid hormones in these subjects was only slightly above normal. A similar relation has been described between duration of suppressive L-thyroxine treatment and bone density in the calcaneus (Lehmke et al., 1992). There is still controversy about the extend to which bone is lost and the influence of menopause during oversubstitution of L-thyroxine to a level of suppressed TSH. Taelman et al. (1990) have reported a $20 \%$ reduction in both proximal and distal forearm bone density in postmenopausal women treated for 10 years with suppressive doses of $\mathrm{L}$ thyroxine. In contrast, in premenopausal women the reduction in proximal forearm bone density, was only $5 \%$, whereas distal forearm density was not reduced in these subjects. The course of treatment of the premenopausal subjects, however, was half the duration in the postmenopausal women. Kung and Pun (1991) have found significantly reduced bone densities in the femoral neck, trochanter, Wards triangle, forearm and pelvis, but not in the axial skeleton, in premenopausal women treated with L-thyroxine. The serum levels of both thyroid hormones and TSH in the treated subjects were comparable with agematched controls. The TSH-assay used in this particular study, however, was a RIA, making a good discrimination between euthyroidism and subclinical thyrotoxicosis in the study population impossible. Lehmke et al. (1992) have reported normal bone density in the forearm and axial skeleton in contrast to a reduced density in the calcaneus in L-thyroxine treated subclinical thyrotoxic 
premenopausal females. Comparable data of decreased peripheral bone density, but normal axial bone density have been described in L-thyroxine treated postmenopausal women (Paul et al., 1988, Lehmke et al., 1992). Chabert-Orsini et al. (1990) could not find either a decline in lumbar bone density in a mixed population of premenopausal and postmenopausal subclinical thyrotoxic women on L-thyrotoxine treatment. In contrast, more exaggerated loss of bone in the axial than in the peripheral skeleton has been described by others, both in pre- and postmenopausal women treated with L-thyroxine (Stall et al., 1990, Pioli et al., 1992). A different effect of thyroid hormone excess on cortical and trabecular bone may well be possible, as was suggested earlier by Meunier et al. (1972) based on histomorphometric studies. In other endocrine bone disease, like in hyperparathyroidism, also a differentiated effect on bone density has been observed (Silverberg et al., 1989). At this stage, however, the available data are too conflicting to decide which type of bone is preferentially susceptible to mild thyroid hormone excess.

Even institution of thyroid hormone replacement therapy in hypothyroidism has been reported to induce loss of bone mass, at least in the first year of treatment (Krølner et al., 1983, Coindre et al., 1986, Ribot et al., 1990). It is not known, if this initial increase in bone loss during L-thyroxine replacement therapy is followed by a "catch-up" bone formation phase in the following years, although Tremollieres (1992) recently has reported a follow-up study which has indicated a complete bone recovery at the spine but not at the femoral neck in the second year of treatment. The studies indicating initial loss of bone during institution of thyroid replacement therapy have been performed in mixed populations of males and females, the women outnumbering the men. A comparable study in a population consisting of only men could not confirm these data during a 3 years follow-up (Toh and Brown, 1990).

Speculations have been made about a possible role of thyrotoxicosis in the distant past as a cause of the L-thyroxine related bone loss. In two recent studies it was found that exclusion of subjects previously treated for thyrotoxicosis abolished the difference in bone density between L-thyroxine treated subjects and controls (Greenspan et al., 1991, Adlin et al., 1991). It could be argued, however, that in the remaining study groups the number of subjects was too small to show a significant difference in bone density. In another recent study (Franklyn et al., 1992), in which a negative effect of L-thyroxine treatment on bone density is disputed, $29 \%$ of the treated subjects had non-suppressed serum TSH-levels. This particular study may actually indicate that if L-thyroxine substitution is carefully monitored no loss of bone would be induced. 
In some studies a contributing role of calcitonine deficiency to bone loss during L-thyroxine treatment, especially in totally thyroidectomized subjects, was suggested (McDermott et al., 1983, Lowery et al., 1986, Diamond et al, 1990, Gonzalez et al., 1991, Adlin et al., 1991). In a comparison of subjects with elevated calcitonine levels after thyroidectomy for medullary thyroid carcinoma with subjects with decreased calcitonine secretory reserve because of subtotal thyroidectomy for benign disease Hurley et al. (1987), however, could not establish a bone-conserving role for calcitonine.

From all of these studies it may be concluded that longterm L-thyroxine treatment is only associated with decreased bone density, when TSH becomes suppressed. This seems especially true in postmenopausal women. We found that Z-scores of forearm bone density are inversely correlated with serum levels of FT4 in women with suppressed TSH and normal thyroid hormone levels (Chapter 4). No such correlation was found in the euthyroid goitre controls. In healthy women no correlation between forearm bone density and thyroid function was found either, although there was a tendency to an inverse correlation between forearm bone density and serum TSH (Chapter 3 ). These data illustrate the value of TSH as a marker for tissue thyroid hormone exposure: serum FT4 seems to be only indicative for the thyroid status at the level of the skeleton when TSH becomes suppressed.

Although decreased bone density is correlated with increased fracture risk (Hui et al., 1989 ), a prospective study of fracture rate in subjects with endogenous subclinical hyperthyroidism would be required to substantiate the clinical significance of the finding of reduced forearm bone density in women with subclinical hyperthyroidism. It would also be of interest if other clinical relevant sites of the skeleton, like the femur and the vertebrae, also show decreased bone density in endogenous subclinical hyperthyroidism. In a recent survey of 1180 patients on L-thyroxine replacement therapy no significant increase in fracture rate was observed in those with suppressed TSH, although there was a trend to a higher incidence of fractures in people over 65 years compared with those who had a normal TSH (Leese et al., 1992). In this particular study, however, only major fractures, requiring hospital admission were considered, which neglects clinically important fractures, like Colles fracture. 
In Chapter 6 is described that women with multinodular goitre who combine suppressed TSH levels with normal levels of thyroid hormones have a slight increase in heart rate without altered cardiac performance as was measured by PEP/LVET ratios. The finding of an increased heart rate is consistent with data of Boutin et al. (1983) who have described that heart rate in subjects with endogenous subclinical hyperthyroidism was midway between euthyroid and hyperthyroid subjects.

The PEP is physiologically represented by the isovolumetric contraction time, which is dependent on heart rate, preload, afterload, stroke volume and ventricular contractility (Weissler et al., 1968, Hirschfeld et al., 1976). Of these, the influence of heart rate is rather small (Weissler et al., 1968, Amidi et al., 1968). Analysis of the different components of the isovolumetric contraction time by Amidi et al. (1968) have shown that the decrease in PEP in hyperthyroidism is mainly the result of an increased myocardial contractility. The LVET is a function of heart rate, stroke volume, mean arterial pressure and ventricular contractility (Weissler et al. 1968, Amidi et al., 1968). Likewise, Amidi et al. (1968) have analyzed that the increase in LVET in hyperthyroidism is largely due to an increased inotropic state. The findings in the present study, combined with these earlier observations suggest that in thyroid hormone excess an increased chronotropy predominates over an increased inotropy. This is in agreement with the finding that the evelated cardiac output during excercise in thyrotoxis is entirely due to an increased heart rate, while stroke volume is not different from normal (Martin III et al., 1991). Moreover, the LVET may actually decrease during excercise in thyrotoxicosis, in contrast to an increase in euthyroidism (Forfar and Caldwell, 1985).

The clinical relevance of altered cardiac function in subclinical hyperthyroidism is illustrated by a high prevalence of atrial fibrillation, as has been documented in a Swedish population with endogenous subclinical hyperthyroidism (Tenerz et al., 1990). Conversely in selected patients presenting with atrial fibrillation subclinical hyperthyroidism may be the underlying condition (Forfar et al., 1979, Bruce et al., 1987). Especially eldery people with multinodular goitre seem to be at risk for this cardiac arrythmia (Forfar et al., 1979, Bruce et al., 1987, Tenerz et al., 1990). Thyrostatic treatment results in return to sinus rhythm, although cardioversion may be needed (Forfar et al., 1981).

A recent study showed an increased risk of ischaemic heart disease in subjects under the age of 65 years on L-thyroxine treatment, but the risk was not different between those with suppressed and normal TSH (Leese et al., 1992). This situation, however, might not be comparable with endogenous subclinical 
hyperthyroidism, since L-thyroxine substituted subjects might have experienced elevated serum cholesterol levels during a preceding phase of hypothyroidism. On the other hand decreased serum cholesterol levels in endogenous subclinical hyperthyroidism (Parle et al., 1992) might increase after thyrostatic treatment, which would possibly influence the risk of myocardial infarction. The net effects of these different influences and the effects of thyrostatic treatment on cardiac morbidity and mortality in endogenous subclinical hyperthyroidism should be evaluated in a prospective study.

\subsection{THYROSTATIC TREATMENT}

In Chapter 7 the results of thyrostatic treatment of 8 postmenopausal women with multinodular goitre and suppressed TSH in combination with normal serum thyroid hormone levels on some parameters of bone metabolism are described during a 2 years follow-up period. The data were compared with those in 8 untreated postmenopausal women with the same condition. It appeared that during thyrostatic treatment neither the serum osteocalcin nor the alkaline phosphatase levels changed significantly. The absence of a change in parameters of osteoblastic function contrasts with the rapid decline in urinary hydroxyproline excretion which was observed soon after the onset of thyrostatic treatment. Noting that activation of bone remodeling units always starts at the level of the osteoclast (Frost, 1969, Parfitt, 1979, Parfitt, 1986), it is not surprising that a decline in osteoblastic parameters may be delayed. Speculatively a possible mechanism for the absence of a decline in the parameters of osteoblastic function could be supposed by a return of depressed PTH levels to normal values during thyrostatic therapy (Ross et al., 1989b). This in its turn could restore the suppressed levels of 1,25 dihydroxyvitamin D3, which is the main activator of osteocalcin production by the osteoblast (Bouillon et al., 1980, Morrison et al., 1989). This possible sequence of events, however, was not explored in this study.

The elevated serum osteocalcin levels in the dynamic phase of thyrostatic treatment should be interpretated different from that in the stable phase of subclinical hyperthyroidism. In the last situation the increase in osteocalcin reflects increased bone turnover, which results in continuing bone loss, as was shown in the 8 postmenopausal women who received no thyrostatic treatment. In the former situation, however, the discrepancy between the lack of change in the parameters of bone formation and the decline in urinary hydroxyproline excretion seems to illustrate the conservation of bone density during thyrostatic treatment. 


\subsection{CONCLUSIONS}

- The second generation IRMA-TSH is a useful firstline thyroid function test in the diagnosis of hyperthyroidism in an outpatient setting of subjects who are suspected for hyperthyroidism. Serum TSH values $>0.1 \mathrm{mU} / \mathrm{l}$ almost definitly exclude hyperthyroidism.

- In healthy women neither bone metabolism nor forearm bone density is influenced by the level of thyroid function within the normal range.

- The existence of correlations both between the serum osteocalcin concentration and age and between forearm bone density and age accounts for the correlation between the serum osteocalcin concentration and forearm bone density. Therefore, the serum osteocalcin concentration is not a useful parameter of bone density.

- In women with untreated multinodular goitre the existence of a suppressed basal serum TSH level is indicative for hyperthyroidism, irrespective of the level of thyroid hormones, as was shown by increased serum concentrations of osteocalcin and alkaline phosphatase, decreased forearm bone density and increased heart rate in these subjects.

- Thyrostatic treatment with methimazole of postmenopausal women with subclinical hyperthyroid multinodular goitre results in a decline in bone resorption without a change in bone formation during the first two years of treatment.

- During thyrostatic treatment forearm bone density in postmenopausal women with subclinical hyperthyroid multinodular goitre is stabilized, while bone loss in untreated women is continued.

- The data on bone metabolism and cardiac function observed in women with subclinical hyperthyroid multinodular goitre indicate that "subclinical" hyperthyroidism is not essentially different from "overt" hyperthyroidism and should be treated as such. 
Adlin E.V., Maurer A.H., Marks A.D., Channick B.J. Bone mineral density in postmenopausal women treated wich L-thyroxine. Am J Med, 1991; 90: 360-366.

Amidi M., Leon D.F., de Groot W.J., Kroetz F.W., Leonard J.J. Effect of the thyroid state on myocardial contractility and ventricular ejection rate in man. Circulation, $1968 ; 38$ : 229-239.

Baran D.T., Braverman L.E. Thyroid hormones and bone mass. J Clin Endocrinol Metab, 1991; 72: 1182-1183.

Bartalena L., Placidi G.F., Martino E., et al. Noctural serum thyrotropin (TSH) surge and the TSH responce to TSH-releasing hormone: dissociated behavior in untreated depressives. $\mathrm{J}$ Clin Endocrinol Metab, 1990; 71: 650-655.

Beresford J.N., Gallagher J.A., Poser J.W., Russell R.G.G. Production of osteocalcin by human bone cells in vitro. Effects of $1,25(\mathrm{OH})_{2} \mathrm{D} 3,24,25(\mathrm{OH})_{2} \mathrm{D} 3$, parathyroid hormone, and glucocorticoids. Metab Bone Dis Rel Res, 1984; 5: 229-234.

Berghout A., Wiersinga W.M., Smits N.J., Touber J.L. The interrelationships between age, thyroid volume, thyroid nodularity and thyroid function in patients with sporadic nontoxic goitre. In: Berghout A. Sporadic nontoxic goitre. Rodopi, Amsterdam. Thesis, 1990: 35-48.

Bijlsma J.W.J., Duursma S.A., Roelofs J.M.M., der Kinderen P.J. Thyroid function and bone turnover. Acta Endocrinol, 1983; 104: 42-49.

Bouillon R, Muls E., de Moor P. Influence of thyroid function on the serum concentration of 1,25-dihydroxyvitamin D3. J Clin Endocrinol Metab, 1980; 51: 793-797.

Boutin J.M., Matte R., D'Amour P., et al. Characteristics of patients with normal T3 and T4 and a low TSH response to TRH. Clin Endocrinol, 1986; 25: 579-588.

Bruce S.A., Rangedara D.C., Lewis R.R., Corless D. Hyperthyroidism in elderly patients with atrial fibrillation and normal thyroid hormone measurements. J Royal Soc Med, 1987; 80: 74-76.

Burman K.D. Is long-term Levothyroxine therapy safe? Arch Intern Med, 1990; 150; 2010-2013.

Caldwell G., Gow S.M., Sweeting V.M., Beckett G.J., Seth J. Toft A.D. Value and limitations of a highly sensitive immunoradiometric assay for thyrotropin in the study of thyrotroph function. Clin Chem, 1987; 33: 303-305.

Caldwell G., Gow S.M., Sweeting V.M., Kellett H.A., Beckett G.J., Seth J. A new strategy for thyroid function testing. Lancet, 1985; I: 1117- 1119.

Chabert-Orsini V., Conte-Devolx B., Thiers-Bautrant D., et al. Densité osseuse après thyrotoxicose iatrogène infraclinique au long cours. Presse Méd, 1990; 19: 1709-1711.

Coindre J M., David J P., Rivière L., et al. Bone loss in hypothyroidism with hormone replacement. Arch Intern Med, 1986; 146: 48-53.

Conference Report. Consensus development conference: prophylaxis and treatment of osteoporosis. Am J Med, 1991; 90: 107-110.

Cooper D.S., Kaplan M.M., Ridgway E.C., Maloof F., Daniels G.H. Alkaline phosphatase isoenzyme patterns in hyperthyroidism. Ann Int Med, 1979; 90: 164-168.

Crowley W.F., Ridgeway E.C., Bough E.W. et al. Noninvasive evaluation of cardiac function in hypothyroidism. Response to gradual thyroxine replacement. N Eng J Med, 1977; 296: 1-6. 
DeFranco D.J., Glowacki J., Cox K.A., Lian J.B. Normal bone particles are preferentially resorbed in the presence of osteocalcin-deficient bone particles in vivo. Calcif Tissue Int, 1991; 49: 43-50.

DeGroot L.J., Mayor G. Admission screening by thyroid function tests in an acute general care teaching hospital. Am J Med, 1992; 93: 558-564.

Delmas P.D., Stenner D., Wahner H.W., Mann K.G., Riggs B.L. Increase in serum bone gamma-carboxyglutamic acid protein with aging in women. J Clin Invest, 1983a; 71: 1316-1321.

Delmas P.D., Wilson D.M., Mann K.G., Riggs B.L. Effect of renal function on plasma levels of bone Gla-protein. J Clin Endocrinol Metab, 1983b; 57: 1028-1030.

Delmas P.D., Demiaux B., Malaval L., Chapuy M.C., Meunier P.J. L'ostéocalcine (ou gla-protéine osseuse), nouveau marqueur biologique pour l'étude de la pathologie osseuse. Presse Med, 1986; 15: 643-646.

Delmas P.D., Christiansen C., Mann K.G., Price P.A. Bone gla protein (osteocalcin) assay standardization report. J Bone Min Res, 1990; 5: 5-11.

Delmas P.D., Schlemmer A., Ginyts E., Riis B., Christiansen C. Urinary excretion of pyridinoline crosslinks correlates with bone turnover measured on iliac crest biopsy in patients with vertebral osteoporosis. J Bone Min Res, 1991; 6: 639-644.

Diamond T., Nery L., Hales I. A therapeutic dilemma: suppressive doses of thyroxine significantly reduce bone mineral measurements in both premenopausal and postmenopausal women with thyroid carcinoma. J Clin Endocrinol Metab, 1990; 72: 1184-1188.

v. Doorn J., Roelfsema F., van der Heide D. Concentrations of thyroxine and 3,5,3'triiodothyronine at 34 different sites in euthyroid rats as determined by an isotopic equilibrium technique. Endocrinol, 1985; 117: 1201-1208.

Duda R.J., O'Brien J.F., Katzmann J.A., Peterson J.M., Mann K.G., Riggs B.L. Concurrent assays of circulating bone gla-protein and bone alkaline phosphatase: effects of sex, age, and metabolic bone disease. J Clin Endocrinol Metab, 1988; 66: 951-957.

Ehrmann D.A., Weinberg M., Sarne D.H. Limitations to the use of a sensitive assay for serum thyrotropin in the assessment of thyroid status. Arch Int Med, 1989; 149: 369-372.

Elders P.J.M., Netelenbos J.C., Lips P. et al. Perimenopausal bone mass and risk factors. Bone Min, 1989; 7: 289-299.

Elte J.W.F., Haak A., Frölich, Wiarda K.S., van Wermeskerken R.K.A. Autonomously functioning euthyroid multinodular goitre. Neth J Med, 1977; 20: 1-4.

Elte J.W.F., Haak A., Wiarda K.S. et al. Propranolol improves the impaired TSH response to TRH in patients with autonomously functioning euthyroid multinodular goitre. Clin Endocrinol, 1982; 15: 553-563.

Elte J.W.F., Bussemaker J.K., Haak A. The natural history of euthyroid multinodular goitre. Postgrad Med J, 1990; 66: 186-190.

Emrich D., Bähre M. Autonomy in euthyroid goitre: maladaptation to iodine deficiency. Clin Endocrinol, 1978; 8: 257-265.

Epstein S., McClintock R., Bryce G. Poser J., Johnston C.C. Jr., Hui S. Differences in serum bone gla protein with age and sex. Lancet, 1984; I: 307-310.

Eriksen E.F., Mosekilde L., Melsen F. Trabecular bone remodeling and bone balance in hyperthyroidism. Bone, 1985; 6: 421-428. 
Eriksen E.P. Normal and pathological remodeling of human trabecular bone: three dimensional reconstruction of the remodeling sequence in normals and in metabolic bone disease. Endocrinol Rev, 1986; 7: 739-410.

Evered D.C., Clark F., Petersen V.B. Thyroid function in euthyroid subjects with autonomous thyroid nodules. Clin Endocrinol, 1974; 3: 149-154.

Faber J., Gam A., Siersbaek-Nielsen K. Improved sensitivity of serum thyrotropin measurements. Studies on serum sex hormone-binding globulin in patients with reduced serum thyrotropin. Acta Endocrinol, 1990a; 123: 535-540.

Faber J., Perrild H., Johansen J.S. Bone gla protein and sex hormone-binding globulin in nontoxic goiter: parameters for metabolic status at the tissue level. J Clin Endocrinol Metab, 1990b; 70; 49-55.

Fallon M.D., Perry III H.M., Bergfeld M., Broke D., Teitelbaum L., Avioli L.V. Exogenous hyperthyroidism with osteoporosis. Arch Intern Med, 1983; 143: 442-444.

Farrugia W., Yates N.A., Fortune C.L., McDougall J.G., Scoggins B.A., Wark J.D. The effect of uninephrectomy on osteocalcin in sheep: a direct evaluation of renal osteocalcin clearence. J Endocrinol, 1991; 130: 213-221.

Fitzsimons D.P., Bodell P.W., Herrick R.E., Baldwin K.M. Effect of thyroid state on cardiac myosin P-light chain phosphorylation during exercise. J Appl Physiol, 1990; 69: 313-320.

Forfar J.C., Miller H.C., Toft A.D. Occult thyrotoxicosis: a correctable cause of "idiopathic" atrial fibrillation. Am J Cardiol, 1979; 44: 9-12.

Forfar J.C., Feek C.M., Miller H.C., Toft A.D. Atrial fibrillation and isolated suppression of the pituitary-thyroid axis: response to specific antithyroid therapy. Int J Cardiol, 1981; 1: 43-48.

Forfar J.C., Caldwell G.C. Hyperthyroid heart disease. Clinics Endocrinol Metab, 1985; 14: 491-508.

Franklyn J.A., Sheppard M.C. Thyroxine replacement treatment and osteoporosis. Br Med J, 1990; 300: 693-694.

Franklyn J.A., Betteridge J., Daykin J., et al. Long-term thyroxine treatment and bone mineral density. Lancet, 1992; 340: 9-13.

Fraser S.A., Smith D.A., Anderson J.B., Wilson G.M. Osteoporosis and fractures following thyrotoxicosis. Lancet, 1971; I: 981-983.

Friedman M.J., Okada R.D., Ewy G.A., Hellman D.J. Left ventricular systolic and diastolic function in hyperthyroidism. Am Heart J, 1982; 104: 1303-1308.

Frost H.M. Tetracycline-based histological analysis of bone remodeling. Calcif Tiss Res, 1969; 3: 211-237.

Gambert S.R. Environmental effects and physiologic variables. In: Wermer and Ingbar's The Thyroid. Eds: Braverman L.E. and Utiger R.D. Lippincott Company Philadelphia, Sixth Ed, 1991: 347-357.

Garrel D.R., Delmas P.D., Malaval L., Toumiaire J. Serum bone Gla protein: a marker of bone turnover in hyperthyroidism. J Clin Endocrinol Metab, 1986; 62: 1052-1055.

Gemsenjäger E., Girard J. Preclinical hyperthyroidism - a graded condition. Acta Endocrinol, 1983; 102: 521-526.

Gemsenjäger E., Staub J.J., Girard J., Heitz Ph. Preclinical hyperthyroidism in multinodular goiter. J Clin Endocrinol Metab, 1976; 43: 810-816. 
Giagulli V.A., Vermeulen A. Increased plasma $5 \alpha$-androstane-3 $\alpha, 17 \beta$-diol glucuronide concentration in clinically euthyroid women with suppressed plasma thyrotropin levels: further evidence for generalized tissue overexposure to thyroid hormones in these subjects. J Clin Endocrinol Metab, 1992; 74: 1465-1467.

Gibold G., Liehn J.C., Deltour G., Delisle M.J. TSH ultrasensible: une nouvelle approche diagnostique de l'hyperthyroïdie. Annales d'Endocrinologie, 1986; 47: 415-419.

Glowacki J., Rey C., Glimcher M.J., Cox K.A., Lian J. A role for osteocalcin in osteoclast differentiation. J Cell Biol, 1991; 45: 292-302.

Gonzalez D.C., Mautalen C.A., Correa P.H., Tamer E.E., Tamer S.E. Bone mass in totally thyroidectomized patients. Role of calcitonin deficiency and exogenous thyroid treatment. Acta Endocrinol, 1991; 124: 521-525.

Gow S.M., Elder A., Caldwell G., et al. An improved approach to thyroid function testing in patients with non-thyroidal illness. Clin Chim Acta, 1986; 158: 49-58.

Greenspan S.L., Greenspan F.S., Resnick N.M., Friedlander A.L., Genant H.K. Skeletal integrity in premenopausal and postmenopausal women receiving long-term L-thyroxine therapy. Am J Med, 1991; 91: 5-14.

Grossman W., Robin N.I., Johnson L.W., Brooks H.L., Selenkow H.A., Dexter L. The enhanced myocardial contractility of thyrotoxicosis. Ann Int Med, 1971; 74: 869-874.

Gundberg C.M., Markowitz M.E., Mizruchi M., Rosen J.F. Osteocalcin in human serum: a circadian rhythm. J Clin Endocrinol Metab, 1985; 60: 736-739.

Van Hamersvelt H.W., Kreutzer H.J.H., Tertoden J.F.W., Thijssen J.H.H. Koppeschaar H.P.F. The immunofluorometric TSH assay: a first-line test for suspected thyroid dysfunction. Neth J Med, 1989; 35: 192-200.

Harvey R.D., McHardy K.C., Reid I.W. et al. Measurement of bone collagen degradation in hyperthyroidism and during thyroxine replacement therapy using pyridinium cross-links as specific urinary markers. J Clin Endocrinol Metab, 1991; 72: 1189-1194.

Hashimoto T., Matsubara F., Nishibu M., Kawai K. Evaluation of a new chemiluminescence technique for human thyrotropin (Berilux hTSH): Diagnostic value of five immunometric assay methods. Eur J Clin Chem Clin Biochem, 1991; 29: 753-757.

Hassager C., Colwell A., Assiri A.M.A., Eastell R., Russell R.G.G., Christiansen C. Effect of menopause and hormone replacement therapy on urinary excretion of pyridinium cross-links: a longitudinal and cross-sectional study. Clin Endocrinol, 1992; 37: 45-50.

Hauschka P.V., Lian J.B., Gallop P.M. Direct identification of the calcium-binding amino acid, gamma-carboxyglutamate, in mineralized tissue. Proc Nat Acad Sci USA, 1975; 72 : 3925-3929.

Van Hemert A.M., Vandenbroucke J.P., Birkenhäger J.C, Valkenburg H.A. Prediction of osteoporotic fractures in the general population by a fracture risk score. Am J Epidemiol, 1990; 132: 123-135.

Hendriks J.Th.A.M., Smeenk D. Investigation of bone and mineral metabolism in hyperthyroidism before and after treatment using calcitonin, ${ }^{47} \mathrm{Ca}$ and balance studies. Acta Endocrinol, 1979: 91: 77-88.

Hennemann G., Docter R., Vos R.A., van Toor H., Krenning E.P. Vergelijking van gebruikelijke schildklierfunctietests met nieuwere TSH-tests bij patienten met ziekten die niet de schildklier betreffen. Ned Tijdschr Geneeskd, 1987; 131: 2355-2359.

Hirschfeld S., Meyer R., Korfhagen J., Kaplan S., Liebman J. The Isovolumic contraction time of the left ventricle. Circulation, 1976; 54: 751-756. 
Hui S.L., Slemenda Ch.W., Johnston C.C.Jr. Age and bone mass as predictors of fracture in a prospective study. J Clin Invest, 1988; 81: 1804-1809.

Hui S.L., Slemenda Ch.W., Johnston C.C.Jr. Baseline measurement of bone mass predicts fracture in white women. Ann Int Med, 1989; 111: 355-361.

Hurley D.L., Tiegs R.D., Wahner H.W., Heath III H. Axial and appendicular bone mineral density in patients with long-term deficiency or excess of calcitonin. N Engl J Med, 1987; 317: 537-541.

Hyldstrup L., Clemmensen I., Jensen B.A., Transbøl I. Non-invasive evaluation of bone formation: measurements of serum alkaline phosphatase, whole body retention of diphosphonate and serum osteocalcin in metabolic bone disorders and thyroid disease. Scan J Clin Lab Invest, 1988; 48: 611-619.

Jarløv A.E., Faber J., Hegedüs L., Mølholm Hansen J. Subtle changes in serum thyrotrophin (TSH) and sex-hormone-binding globulin (SHBG) levels during long-term follow-up after radioactive iodine in multinodular non-toxic goitre. Clin Endocrinol, 1992; 37: 335-337.

Jastrup B., Mosekilde L., Melsen F., Lund Bi., Lund Bj., Sørensen O.H. Serum levels of vitamin $\mathrm{D}$ metabolites and bone remodelling in hyperthyroidism. Metabolism, 1982; 31 : 126-132.

John R., Henley R., Chang D., McGregor A.M. Enhanced luminescence immunoassay: evaluation of a new, more sensitive thyrotropin assay. Clin Chem, 1986; 32: 2178-2183.

Johnston C.C.Jr., Slemenda Ch.W., Melten L.J. Clinical use of bone densitometry. N Eng J Med, 1991; 324: 1105-1109.

Jüppner H., Schettler T., Giebel G., Wenner S., Hesch R.D. Radioimmunoassay for human osteocalcin using an antibody raised against the synthetic human (h37-49) sequence. Calcif Tissue Int, 1986; 39: 310-315.

Kanzaki S., Hosoda K., Morinake T. et al. Serum propeptide and intact molecular osteocalcin in normal children and in children with growth hormone (GH) deficiency: a potential marker of bone growth and response to therapy. J Clin Endocrinol Metab, 1992; 75 : 1104-1109.

Kaplan G.C., Eilon G., Poser J.W., Jacobs J.W. Constitutive biosynthesis of bone gla protein in a human osteosarcoma cell line. Endocrinol, 1985; 117; 1235-1238.

Kivirikko K.I., Laitinen O., Lamberg B.A. Value of urine and serum hydroxyproline in the diagnosis of thyroid disease. J Clin Endocrinol, 1965; 25: 1347-1352.

Klee G.G., Hay I.D. Assessment of sensitive thyrotropin assays for an expanded role in thyroid function testing: proposed criteria for analytic performance and clinical utility. J Clin Endocrinol Metab, 1987; 64: 461-471.

Knapen M.H.J., Hamulyak K., Vermeer C. The effect of vitamin K supplementation on circulating osteocalcin (Bone Gla Protein) and urinary calcium excretion. Ann Int Med, 1989; 111: 1001-1005.

Kraenzlin M.E., Lau K.-H.W., Liang L., et al. Development of an immunoassay for human serum osteoclastic tartrate-resistant acid phosphatase. J Clin Endocrinol Metab, 1990; 71 : 442-451.

Krenning E.P., Hennemann G. Effect van veroudering op het schildkliermetabolisme en klinische implicaties daarvan. Ned Tijdschr Geneeskd, 1986; 130: 249-253. 
Krølner B., Vesterdal Jørgensen J., Pors Nielsen S. Spinal bone mineral content in myxoedema and thyrotoxicosis. Effects of thyroid hormone(s) and antithyroid treatment. Clin Endocrinol, 1983; 18: 439-446.

Kreutzer H.J.H., Tertoolen J.F.W., Thijssen J.H.H., der Kinderen P.J., Koppeschaar H.P.F. Analytical evaluation of four sensitive assays of thyrotropin, including effects of variations in patient sampling. Clin Chem, 1986: 32: 2085-2090.

Kung A.W.C., Pun K.K. Bone mineral density in premenopausal women receiving longterm physiological doses of Levothyroxine. JAMA, 1991; 265: 2688-2691.

Larsen P.R. Thyroid-pitiutary interaction-feedback regulation of thyrotropin secretion by thyroid hormones. N Eng J Med, 1982; 306: 23-32.

Larsen P.R., Alexander N.M. Chopra I.J. et al. Revised nomenclature for tests of thyroid hormones and thyroid-related proteins in serum. J Clin Endocrinol Metab, 1987; 64: 1089-1094.

Lau K.-H.W., Onishi T., Wergedal J.E., Singer F.R., Baylink D.J. Characterization and assay of tartrate-resistant acid phosphatase activity in serum: potential use to assess bone resorption. Clin Chem, 1987; 33: 458-462.

Lee M.S., Kim S.Y., Lee M.C., et al. Negative correlation between the change in bone mineral density and serum osteocalcin in patients with hyperthyroidism. J Clin Endocrinol Metab, 1989; 70: 766-770.

Leese G.P., Jung R.T., Guthrie C., Waugh N., Brouning M.C.K. Morbidity in patients on L-thyroxine: a comparison of those with normal TSH to those with suppressed TSH. Clin Endocrinol, 1992; 37; 500-503.

Lehmke J., Bogner U., Felsenberg D., Peters H., Schleusener H. Determination of bone mineral density by quantitative computed tomography and single photon absorptiometry in subclinical hyperthyroidism: a risk of early osteopaenia in post-menopausal women. Clin Endocrinol, 1992; 36: 511-517.

Levey G.S., Klein I. Catecholamine-thyroid hormone interactions and the cardiovascular manifestations of hyperthyroidism. Am J Med, 1990; 88: 642-646.

Lewis B.S., Ehrenfeld E.N., Lewis N., Gotsman M.S. Echocardiographic LV function in thyrotoxicosis. Am Heart J, 1979; 97: 460-468.

Lian J., Stewart C., Puchacz E., et al. Structure of the rat osteocalcin gene and regulation of vitamin D-dependent expression. Proc Natl Acad Sci USA, 1989; 86: 1143-1147.

Lien E., Aanderud S. Systolic time intervals in the evaluation of thyroid dysfunction. Acta Med Scan, 1982; 211: 265-268.

Lind P., Klima G., Költringer P., Langsteger W., Eber O. Negativer TRH-Test: Differenzierte Neubewertung durch empfindliche TSH-Bestimmung. Schweiz Med Wschr, 1988; 188: 1130-1134.

Linde J., Friis Th. Osteoporosis in hyperthyroidism estimated by photon absorptiometry. Acta Endocrinol, 1979; 91: 437-448.

Lowery W.D., Thomas C.G., Awbrey B.J., Rosenstein B.D., Talmage R.V. The late effect of subtotal thyroidectomy and radioactive iodine therapy on calcitonin secretion and bone mineral density in women treated for Graves' disease. Surgery, 1986; 100: 1142-1149.

Lukert B.P., Higgins J.C., Stoskoph M.M. Serum osteocalcin is increased in patients with hyperthyroidism and decreased in patients receiving glucocorticoids. J Clin Endocrinol Metab, 1986; 62: 1056-1058. 
Markose E.R., Stein J.L., Stein G.S., Lian J.B. Vitamin D-mediated modifications in protein-DNA interactions at two promoter elements of the osteocalcin gene. Proc Natl Acad Sci USA, 1990; 87: 1701-1705.

Martin III W.H., Spina R.J., Korte E. et al. Mechanisms of impaired exercise capacity in short duration experimental hyperthyroidism. J Clin Invest, 1991; 88: 2047-2053.

Martinez M.E., Herranz L., de Pedro C., Pallardo L.F. Osteocalcin levels in patients with hyper-and hypothyroidism. Horm Metab Res, 1986; 18: 212-214.

McDermott M.T., Kidd G.S., Blue P., Ghaed V., Hofeldt F.D. Reduced bone mineral content in totally thyroidectomized patients: possible effect of calcitonin deficiency. $\mathrm{J}$ Clin Endocrinol Metab, 1983; 56: 936-939.

Melsen F., Mosekilde L. Morphometric and dynamic studies of bone changes in hyperthyroidism. Acta Path Microbiol Scand Sect A, 1977; 85: 141-150.

Melton L.J., Eddy D.M., Johnston C.C.Jr. Screening for osteoporosis. Ann Int Med, 1990; 112: 516-528.

Meunier P.J., Bianchi G.G.S., Edouard C.M., Bernard J.C., Courpron P., Vignon G.E. Bony manifestations of thyrotoxicosis. Orth Clin North Am, 1972; 3: 745-774.

Miller J.M., Block M.A. Functional autonomy in multinodular goitre. JAMA, 1970; 214: 535-539.

Mintz G., Pizzarello R., Klein I. Enhanced left ventricular diastolic function in hyperthyroidism: noninvasive assessment and responce to treatment. J Clin Endocrinol Metab, 1991; 73: 146-150.

Morrison N.A., Shine J., Fragonas J.Ch., Verkest V., McMenemy, Eisman J.A. 1,25Dihydroxyvitamin D-responsive element and glucocorticoid repression in the osteocalcin gene. Science, 1989; 246: 1158-1161.

Mosekilde L., Eriksen E.F., Charles P. Effects of thyroid hormones on bone and mineral metabolism. Endocrinol Metab Clin North Am, 1990; 19: 35-63.

Mosekilde L., Christensen M.S. Decreased parathyroid function in hyperthyroidism: interrelationships between serum parathyroid hormone, calcium-phosphorus metabolism and thyroid function. Acta Endocrinol, 1977; 84: 566-575.

Mosekilde L., Christensen S.M., Melsen F., Schwartz Sørensen N. Effects of antithyroid treatment on calcium-phosphorus metabolism in hyperthyroidism. I: Chemical quantities in serum and urine. Acta Endocrinol, 1978; 87: 743-750.

Mosekilde L., Jastrup B., Melsen F., et al. Effects of propranolol treatment on bone mass, bone mineral content, bone remodelling, parathyroid function and vitamin D metabolism in hyperthyroidism. Eur J Clin Invest, 1984; 14: 96-102.

Mundy G.R., Shapiro J.L., Bandelin J.G., Canalis E.M., Raisz L.G. Direct stimulation of bone resorption by thyroid hormones. J Clin Invest, 1976; 58: 529-534.

Nicoloff J.T., Spencer C.A. The use and misuse of the sensitive thyrotropin assays. J Clin Endocrinol Metab, 1990; 71: 553-558.

Nielsen H.K., Brixen K., Mosekilde L. Diumal rhythm in serum activity of wheat-germ lectin-precipitable alkaline phosphatase: temporal relationships with the diurnal rhythm of serum osteocalcin. Scan J Clin Lab Invest, 1990a; 50: 851-856.

Nielsen H.K., Brixen K., Mosekilde L. Diurnal rhythm and 24-hour integrated concentrations of serum osteocalcin in normals: influence of age, sex, season, and smoking habits. Calcif Tissue Int, 1990b; 47: 284-290. 
Nielsen H.K., Lundby L, Rasmusen K, Charles P., Hansen C. Alcohol decreases serum osteocalcin in a dose-dependent way in normal subjects. Calcif Tissue Int, 1990c; 46: 173-178.

Nielsen H.K., Brixen K., Kassem M., Mosekilde L. Acute effect of 1,25-dihydroxyvitamin $\mathrm{D}_{3}$, prednisone, and 1,25-dihydroxyvitamin $\mathrm{D}_{3}$ plus prednisone on serum osteocalcin in normal individuals. J Bone Min Res, 1991; 6: 435-441.

Nielsen H.K., Brixen K., Kassem M., Charles P., Mosekilde L. Inhibition of the mornig cortisol peak abolishes the expected moming decrease in serum osteocalcin in normal males: evidence of a controlling effect of serum cortisol on the circadian rhythm in serum osteocalcin. J Clin Endocrinol Metab, 1992; 74: 1410-1414.

Nishimoto S.K., Price P.A. Secretion of the vitamin K-dependent protein of bone by rat osteosarcoma cells. J Biol Chem, 1980; 255: 6579-6583.

Obregon M.J., Roelfsema F., De Escobar G.M., Escobar del Rey F., Querido A. Exchange of triiodothyronine derived from thyroxine with circulating triiodothyronine as studied in the rat. Clin Endocrinol, 1979; 10: 305-315.

Ohta T., Mori M., Koshiba H., Takada J., Matsuyama T., Ishii S. Production of monoclonal antibodies specific for human bone gamma-carboxyglutamic acid containing protein. Virchov Archiv Pathol Anat, 1991; 418: 499-502.

Oppenheimer J.H. Thyroid hormone action at the molecular level. In: Werner and Ingbar's The Thyroid. Eds: Braverman L.E. and Utiger R.D. Lippincott Company Philadelphia, Sixth Ed., 1991: 204-224.

Ormston B.J., Cryer R.J., Garry R., Besser G.M. Thyrotropin-releasing hormone as a thyroid-function test. The Lancet, 1971; II: 10-14.

Orwoll E.S., Deftos L.J. Serum osteocalcin (BGP) levels in normal men: a longitudinal evaluation reveals an age-associated increase. J Bone Min Res, 1990; 5: 259-262.

Overgaard K., Nilas L., Johansen J.S., Christiansen C. Lack of seasonal variation in bone mass and biochemical estimates of bone tumover. Bone, 1988; 9: 285-288.

Parfitt A.M. Remodeling and microstructure of bone: relation to pathogenesis of age related fractures. In: Second international conference on osteoporosis. Social and clinical aspects. Masson, Milano, 1986: 104-119.

Parfitt A.M. Quantum concept of bone remodeling and turnover: implications for the pathogenesis of osteoporosis. Calcif Tissue Int, 1979; 28: 1-5.

Parisi A.F., Hamilton B.P., Thomas C.N., Mazzaferri E.L. The short cardiac pre-ejection period. Circulation, 1974; 49: 900-904.

Parle J.V., Franklyn J.A. Cross K.W., Jones S.C., Sheppard M.C. Prevalence and follow-up of abnormal thryotropin (TSH) concentrations in the elderly in the United Kingdom. Clin Endocrinol, 1991; 34: 77-83.

Parle J.V., Franklyn J.A. Cross K.W., Jones S.R., Sheppard M.C. Circulating lipids and minor abnormalities of thyroid function. Clin Endocrinol, 1992; 37: 411-414.

Paul T.L., Kerrigan J., Kelly A.M., Braverman L.E., Baran D.T. Long-term L-thyroxine therapy is associated with decreased hip bone density in premenopausal women. JAMA, $1988 ; 259: 3137-3141$.

Peerenboom H., Keck E., Krüskemper L., Strohmeyer G. The defect of intestinal calcium transport in hyperthyroidism and its response to therapy. J Clin Endocrinol Metab, 1984; 59: $936-940$.

Perry III H.M. Thyroid replacent and osteoporosis. Arch Intern Med, 1986; 146: 41-42. 
Pietschmann P., Resch H., Woloszczuk W., Willvonseder R. A circadian rhythm of serum osteocalcin levels in postmenopausal osteoporosis. Eur J Clin Invest, 1990; 20: 310-312.

Pioli G., Pedrazzoni M., Palummeri E. Longitudinal study of bone loss after thyroidectomy and suppressive thyroxine therapy in premenopausal women. Acta Endocrinol, 1992; 126: 238-242.

Popelier M., Jollivet B., Fouquet B., et al. Etude du métabolisme phospho-calcique dans l'hyperthyroïdie. Presse Méd., 1990; 19: 705-708.

Price D.E., O'Malley B.P., Northover B., Rosenthal F.D. Changes in circulating thyroid hormone levels and systolic time intervals in acute hypothyroidism. Clin Endocrinol, 1991; 35: 67-69.

Price P.A., Otsuka A.S., Poser J.W., Kristaponis J., Raman N. Characterization of a gammacarboxyglutamic acid-containing protein from bone. Proc Natl Acad Sci USA, 1976; 73: 1447-1451.

Price P.A., Nishimoto S.K. Radioimmunoassay for the vitamin K-dependent protein of bone and its discovery in plasma. Proc Natl Acad Sci USA, 1980a; 77: 2234-2238.

Price P.A., Parthemore J.G., Deftos L.J. New biochemical marker for bone metabolism. J Clin Invest, $1980 \mathrm{~b} ; 66: 878-883$.

Von Recklinghausen F. Die Fibröse oder deformierende Ostitis, die Osteomalacie und die osteoplastische Carcinose in Ihren gegenseitigen Beziehungen. In: Festschrift Virchow $\mathbf{R}$. Reemer, Berlin, 1891: 1-89.

Ribot C., Tremollieres F. Pouilles J.M., Louvet J.P. Bone mineral density and thyroid hormone therapy. Clin Endocrinol, 1990; 33: 143-153.

Rizzoli R., Poser J., Bürgi U. Nuclear thyroid hormone receptors in cultured bone cells. Metabolism, 1986; 35: 71-74.

Ross D.S., Neer R.M., Ridgway E.C., Daniels G.H. Subclinical hyperthyroidism and reduced bone density as a possible result of prolonged suppression of the pituitary-thyroid axis with L-thyroxine. Am J Med, 1987; 82: 1167-1170.

Ross D.S., Ardisson L.J., Meskell M.J. Measurements of thyrotropin in clinical and subclinical hyperthyroidism using a new chemiluminescent assay. J Clin Endocrinol Metab, 1989a; 69: 684-688.

Ross D.S., Nussbaum S.R. Reciprocal changes in parathyroid hormone and thyroid function after radioiodine treatment of hyperthyroidism. J Clin Endocrinol Metab, 1989b; 68: 1216-1219.

Ross D.S., Daniels G.H., Gouveia D. The use and limitations of a chemiluminescent thyrotropin assay as a single thyroid function test in an out-patient endocrine clinic. J. Clin Endocrinol Metab, 1990; 71: 764-769.

Ross D.S. Monitoring L-thyroxine therapy: Lessons from the effects of L-thyroxine on bone density. Am J Med, 1991a; 91: 1-4.

Ross D.S. Subclinical hyperthyroidism. In: Werner and Ingbar's The Thyroid. Eds. Braverman L.E. and Utiger R.D. Lippincott Company Philadelphia, USA, Sixth ed., 1991b: 1249-1255.

Ross D.S., Ardisson L.J., Nussbaum S.R., Meskell M.J. Serum osteocalcin in patients taking L-thyroxine who have subclinical hyperthyroidism. J Clin Endocrinol Metab, 1991c, 72: 507-509.

Ruffie A., Fossats A., Colle M. Valeurs normales de l'osteocalcine sérique au cours de la vie. Ann Biol Clin, 1989; 47: 629-634. 
Sato K., Han D.C., Fujii Y., Tsushima T., Shizume K. Thyroid hormone stimulates alkaline phosphatase activity in cultured rat osteoblastic cells (ROS 17/2.8) through 3,5,3'-triiodoL-thyronine nuclear receptors. Endocrinol, 1987; 120: 1873-1881.

Sawin C.T., Geller A., Kaplan M.M., Bacharach P., Wilson P.W.F., Hershman J.M. Low serum thyrotropin (thyroid-stimulating-hormone) in older persons without hyperthyroidism. Arch Intern Med, 1991; 151: 165-168.

Schlote B., Nowotry B., Schaaf L. et al. Subclinical hyperthyroidism: physical and mental state of patients. Eur Arch Psychiatry Clin Neurosci, 1992; 241: 357-364.

Seth J., Kellett H.A., Caldwell G., et al. A sensitive immunoradiometric assay for serum thyroid stimulating hormone: a replacement for the thyrotrophin releasing hormone test? Br Med J, 1984; 289: 1334-1336.

Siersbaek-Nielsen K., Skovsted L., Mølholm Hansen J., Kristensen M., Korsgaard Christensen L. Hydroxyproline excretion in the urine and calcium metabolism during long-term treatment of thyrotoxicosis with propylthiouracil. Acta Med Scan, 1971; 189: 485-488.

Silverberg S.J., Shane E., De la Cruz L. et al. Skeletal disease in primary hyperparathyroidism. J Bone Min Res, 1989; 4: 283-291

Smeulers J., Docter R., Visser T.J., Henneman G. Response to thyrotrophin-releasing-hormone and triiodothyronine suppressibility in euthyroid multinodular goitre. Clin Endocrinol, 1977; 7: 389-397.

Snapper I. De ziekte van Recklinghausen (ostitis fibrosa cystica generalisata of hyperparathyreoïdie). In: Ziekten van het skelet. Ed. Snapper I. De Erven Bohn, Haarlem, 1937: 1-79.

Spencer C.A., LoPresti J.S., Patel A., et al. Applications of a new chemiluminometric thyrotropin assay to subnormal measurement. J Clin Endocrinol Metab, 1990; 70: 453460.

Stall G.M., Harris S., Sokoll L.J., Dawson-Hughes B. Accelerated bone loss in hypothyroid patients overtreated with L-thyroxine. Ann Intern Med, 1990; 113: 265-269.

Stepán J.J., Pospíchal J., Schreiber V. The application of plasma tartrate-resistant acid phosphatase to assess changes in bone resorption in response to artificial menopause and its treatment with estrogen or norethisterone. Calcif Tissue Int, 1989; 45: 273-280.

Studer H., Hunziker H.R., Ruchti C. Morphologic and functional substrate of thyrotoxicosis caused by nodular goitres. Am J Med, 1978; 65: 227-234.

Studer H., Peter H.J., Gerber. Toxic nodular goitre. Clinics Endocrinol Metab, 1985; 14 : 351-372.

Surks M.I., Chopra I.J., Mariash C.N., Nicoloff J.T., Solomon D.M. American Thyroid Association guidelines for use of laboratory tests in thyroid disorders. JAMA, 1990; 16: 1529-1532.

Szabolcs I., Ploenes Chr., Bernard W., Herrmann J. Screening of geriatric patients for thyroid dysfunction with thyrotropin-releasing-hormone test, sensitive thyrotropin and free thyroxine estimation. Horm Metab Res, 1990; 22: 298-302.

Taelman P., Kaufman J.M., Janssens X., Vandecauter H., Vermeulen A. Reduced forearm bone mineral content and biochemical evidence of increased bone tumover in women with euthyroid goitre treated with thyroid hormone. Clin Endocrinol, 1990; 33: 107-117.

Tarallo P., Henny J., Foumier B., Siest G. Plasma osteocalcin: biological variations and reference limits. Scan J Clin Lab Invest, 1990; 50: 649-655. 
Tenerz $\AA$., Forberg R., Jansson R. Is a more active attitude warranted in patients with subclinical thyrotoxicosis? J Intern Med, 1990; 228: 229-233.

Thomsen K., Eriksen E.F., Jørgensen J.C.R., Charles P., Mosekilde L. Seasonal variation of serum bone GLA protein. Scan J Clin Lab Invest, 1989; 49: 605-611.

Tibi L., Patrick A.W., Leslie P., Toft A.D., Smith A.F. Alkaline phosphatase isoenzymes in plasma in hyperthyroidism. Clin Chem, 1989; 35: 1427-1430.

Toft A.D. Thyroxine replacement therapy. Clin Endocrinol, 1991; 34: 103-105.

Toh S.H., Claunch B.C., Brown P.H. Effects of hyperthyroidism and its treatment on bone mineral content. Arch Intern Med, 1985; 145: 883-886.

Toh S.H., Brown P.H. Bone mineral content in hypothyroid male patients with hormone replacement: a 3-year study. J Bone and Min Res, 1990; 5: 463-467.

Tracy R.P., Andianorivo A., Riggs B.L., Mann K.G. Comparison of monoclonal and polyclonal antibody-based immunoassays for osteocalcin: a study of sources in variation in assay results. J Bon Min Res, 1990; 5: 451-461.

Tremollieres F. Bone mass and bone metabolism during replacement therapy for hypothyroidism. In: Treatment of established osteoporosis - Primary and endocrine bone disease. Abstract book First European Conference on Osteoporosis. Nice, 1992: 72-73.

Tseng K.H., Walfish P.G., Persaud J.A., Gilbert B.W. Concurrent aortic and mitral valve echocardiography permits measurement of systolic time intervals as an index of peripheral tissue thyroid functional status. J Clin Endocrinol Metab, 1989; 69: 633-638.

Uebelhart D., Schlemmer A., Johansen J.S., Gineyts E., Christiansen C., Delmas P.D. Effect of menopause and hormone replacement therapy on the urinary excretion of pyridinium cross-links. J Clin Endocrinol Metab, 1991; 72: 367-373.

Valcavi R., Menozzi C., Roti E. Sinus node function in hyperthyroid patients. J Clin Endocrinol Metab, 1992; 75: 239-242.

Vanderschueren D., Gevers G., Raymaekers G., Devos P., Dequeker J. Sex- and age-related changes in bone and serum osteocalcin. Calcif Tissue Int, 1990; 46: 179-182.

Vanderschueren D., Gevers G., Dequeker J., et al. Seasonal variaton in bone metabolism in young healthy subjects. Calcif Tissue Int, 1991; 49: 84-89.

Vermeer C. Gamma-carboxyglutamate-containing proteins and the vitamin K-dependent carboxylase. Biochem J, 1990; 266: 625-636.

Vermeulen A.H.M., Vermeer C., Bosman F.T. Histochemical detection of osteocalcin in normal and pathological human bone. J Hist Cyto, 1989; 37: 1503-1508.

Wakasygi M., Wakao R., Tawata M., Gan N., Koizumi K., Onaya T. Bone mineral density in patients with hyperthyroidism measured by dual energy $\mathrm{X}$-ray absorptiometry. Clin Endocrinol, 1993; 38: 283-286.

Weinberger C., Thompson C.C., Ong E.S., Lebo R., Gruol D.J., Evans R.M. The c-erb-A gene encodes a thyroid hormone receptor. Nature, 1986; 324: 641-646.

Weissler P., Harris W.S., Schoenfeld C.D. Systolic time intervals in heart failure in man. Circulation, 1968; 37: 149-159.

Wiarda K.S., Elte J.W.F., Haak A. Thyroid suppressibility and functional autonomy in euthyroid multinodular goitre. In: Nuklear Medizin. Eds. Schmidt H.A.E. and Woldring M.F.K. Schattaner Verlag, Stuttgart, 1978: 716-719.

Wiersinga W.M., Endert E., Trip M.D., Verhaest-de Jong N. Immunoradiometric assay of thyrotropin in plasma: its value in predicting response to thyroliberin stimulation and assessing thyroid function in amiodarone-treated patients. Clin Chem, 1986; 32: 433-436. 
Wiersinga W.M. and Krenning E.P. Hyperthyreoidie. In: Schildklierziekten. Eds. Wiersinga W.M. and Krenning E.P. Samson Stafleu. Alphen a/d Rijn, 1988: 98-121.

Wilke T.J., Utley D.J. The role of precision in determing the performance of a thyrotropin assay in diagnosing hyperthyroidism. Clin Chem, 1988; 34: 1464-1467.

Wood W.G., Waller D., Hantke U. An evaluation of six solid-phase thyrotropin (TSH) kits. J Clin Chem Clin Biochem, 1985; 23: 461-471.

Worsfold M., Sharp C.A., Davie M.W.J. Serum osteocalcin and other indices of bone formation: an 8-decade population study in healthy men and women. Clin Chim Acta, 1988; 178: 225-236. 


\section{Chapter 9}

\section{SUMMARY}

SAMENVATTING 


\section{SUMMARY}

In Chapter 1 the concept of subclinical hyperthyroidism is discussed and the influence of thyroid hormones on bone and heart is summarized. The aim of this study was to explore the impact of spontaneous subclinical hyperthyroidism on some target tissues. Bone, as a slow changing parameter, and the heart, as a fast changing parameter, were chosen as target tissues. The group of interest consisted of females with multinodular goitre.

In Chapter 2 a survey is described in which the value of a "second generation" immuno-radiometric assay (IRMA) of TSH as a first line thyroid function test was defined in 36 subjects suspected for hyperthyroidism. Seventeen of these subjects had a subnormal response in the TRH-test (increase, measured by a radio-immuno assay (RIA), in TSH less than $1.0 \mathrm{mU} / \mathrm{l}$ ). At a discrimination value of TSH $=0.1 \mathrm{mU} / 1$ basal TSH-IRMA appeared to have a very high predictive value for the outcome of the TRH-test (positive and negative predictive value 1 and 0.95 , respectively). In the subjects with a normal response in the TRH-test $(n=19)$ basal TRH-IRMA correlated closely with the increase in TSH (measured by RIA) after TRH stimulation ( $y=0.13+0.13 x ; r=0.897 ; P$ $<0.001$ ). Based on these data "subclinical hyperthyroidism" was defined as suppressed basal serum TSH (= basal TSH $<0.1 \mathrm{mU} / \mathrm{l})$ in combination with normal serum thyroid hormone levels.

In Chapter 3 the interrelationships between serum osteocalcin, forearm bone density (measured by single photon absorptiometry), thyroid function parameters, age and body mass are explored in a cross-sectional study in 125 healthy women, aged between 21 and 75 years. Measurements in two different periods of a year showed neither differences in serum osteocalcin values nor in parameters of thyroid function. The serum concentration of osteocalcin was independently correlated with age and body mass index (osteocalcin = $9.774571+0.080023$ age (1) -0.12621 body mass index ${ }^{(2)}$, multiple $\mathrm{r}=0.39$; $\mathrm{P}^{(1)}<0.0001, \mathrm{P}^{(2)}=0.013$ ). No correlations were found between osteocalcin and thyroid function parameters. Inverse correlations between osteocalcin and both proximal and distal bone density appeared to be determined by age related variations in both parameters. The best fitting correlation between serum osteocalcin and age was obtained with cubic regression analysis $(y=23.86536$ $1.080274 x+0.024269 x^{2}-0.000161 x^{3} ; r=0.39 ; P=0.0002$ ). Also the relation between distal, respectively proximal, forearm bone density and age was best described with cubic regression analysis $(y=0.974144-0.002408 x+$ $0.000227 x^{2}-0.000004 x^{3} ; r=0.59 ; P<0.0001$ and $y=1.506425-0.020131 x+$ 
$0.000674 x^{2}-0.000007 x^{3} ; r=0.65 ; P<0.0001$, respectively). There were no independent correlations between forearm bone density and thyroid function parameters.

It is concluded that in healthy women the level of thyroid function has no influence on bone metabolism, nor on bone density. Since age related variations in both the serum osteocalcin concentration and forearm bone density account for the correlation between these two parameters it is concluded that the serum osteocalcin concentration is not a good parameter for bone density.

In Chapter 4 forearm bone densities in 23 women with subclinical hyperthyroid multinodular goitre are compared with those in 54 women with euthyroid multinodular goitres. The data were expressed as Z-scores related to the data in the 125 healthy females described in Chapter 3. The subclinical hyperthyroid subjects were significantly older than the euthyroid subjects (median (range) ages 57.2 (37-70.7) years vs 48.6 (24-69.8) years; $\mathrm{P}<0.01$ ) and had a significantly higher median (range) serum FT4 concentration (15.6 (1123.2) $\mathrm{pmol} / \mathrm{l}$ vs $11.9(8.3-18.3) \mathrm{pmol} / \mathrm{l} ; \mathrm{P}<0.001$ ). Mean $( \pm \mathrm{SEM}) \mathrm{Z}$-scores of both distal and proximal bone density appeared to be lower in the subclinical hyperthyroid than in the euthyroid goitre subjects $(-0.69 \pm 0.17$ vs $-0.1 \pm 0.18$; $P<0.05$ and $-0.5 \pm 0.18$ vs $0.07 \pm 0.18 ; P<0.05$, respectively). In contrast to what was found in the euthyroid subjects, FT4 correlated inversely with Zscores of both distal and proximal forearm bone density in the subjects with subclinical hyperthyroidism $(\mathrm{r}=-0.42 ; \mathrm{P}<0.05$ and $\mathrm{r}=-0.45 ; \mathrm{P}<0.05$, respectively).

In Chapter 5 serum osteocalcin and alkaline phosphatase concentrations in the subjects described in Chapter 4 are compared. Both median (range) osteocalcin and alkaline phosphatase concentrations in serum were higher in the subclinical hyperthyroid than in the euthyroid multinodular goitre subjects (12.4 (6.7-19.6) $\mu \mathrm{g} / \mathrm{l}$ vs $9.9(4.6-18.8) \mu \mathrm{g} / \mathrm{l} ; \mathrm{P}=0.01$ and 74 (42-95) $\mathrm{U} / 1$ vs 55 (29-94) $\mathrm{U} / \mathrm{i} ; \mathrm{P}=0.0034$, respectively). Expression of the osteocalcin data as $\mathrm{Z}$-scores revealed that the difference in serum osteocalcin concentrations was not due to the difference in age between the groups (median (range) $\mathrm{Z}$-score of osteocalcin in subclinical hyperthyroid vs euthyroid goitre subjects 0.33 (- 1.57 to 3.83 ) vs $-0.16(-2.84$ to 3.13$) ; P=0.0225)$. Both in the euthyroid and in the subclinical hyperthyroid subjects osteocalcin correlated significantly with alkaline phosphatase $(r=0.51 ; P<0.001$ and $r=0.45 ; P=0.0313$; respectively). These data indicate that bone tumover in women with subclinical hyperthyroid multinodular goitre is increased in comparison with euthyroid multinodular goitre subjects. 
In Chapter 6 a survey is described in which some cardiac effects of endogenous subclinical hyperthyroidism are explored in a cross-sectional study in 27 women with subclinical hyperthyroid multinodular goitre and in 27 women with euthyroid multinodular goitre. Systolic time intervals, expressed as the ratio of the pre-ejection period (PEP) to the left ventricular ejection time (LVET), were measured from simultaneous electrocardiographic and M-mode echocardiographic tracings, obtained from a two-dimensional echocardiogram. No significant difference between the mean ( \pm SD) PEP/LVET ratios in the two groups was observed $(0.266 \pm 0.049$ vs $0.281 \pm 0.048$; N.S.). Mean $( \pm$ SD) resting heart rate, however, was higher in the subclinical than in the euthyroid multinodular goitre subjects $(89.7 \pm 12.9$ beats $/ \mathrm{min}$ vs $80 \pm 14.4$ beats $/ \mathrm{min} ; \mathrm{P}=$ 0.012).

In Chapter 7 some longitudinal data are presented concerning bone metabolism and forearm bone density in 8 postmenopausal women with subclinical hyperthyroid multinodular goitre during monotherapy with methimazole. These data are compared with those obtained in 8 untreated postmenopausal women with the same condition. The follow-up period in this study was up to 24 months. Thyrostatic treatment in the 8 postmenopausal women with subclinical hyperthyroidism resulted in a rapid decline in urinary hydroxyproline excretion. No significant changes in the serum concentrations of osteocalcin and alkaline phosphatase levels, nor in urinary calcium excretion were observed. In the treatment group forearm bone density remained stable during the observation period. In contrast, in the untreated subjects a gradual loss of forearm bone density was observed, which was significant $(\mathrm{P}<0.05)$ for the distal site. It was concluded that bone loss in postmenopausal women with subclinical hyperthyroid multinodular goitre is settled down by thyrostatic treatment with methimazole, while it continues if subclinical hyperthyroidism is left untreated.

The studies described in this thesis indicate that "subclinical" hyperthyroidism is not essentially different from "overt" hyperthyroidism and should be treated as such. 


\section{SAMENVATTING}

In Hoofdstuk I wordt het begrip "subklinische hyperthyreodie" besproken en er wordt een samenvatting gegeven van de invloed van schildklierhormonen op het bot en het hart. Het doel van het onderzoek beschreven in dit proefschrift was na te gaan wat de invloed van spontane subklinische hyperthyreoïdie is op enkele doelorganen van schildklierhormonen. Bot, als een langzaam veranderende parameter, en het hart, als een snel veranderende parameter, werden gekozen als doelorganen. De onderzoeksgroep bestond uit vrouwen met multinodulair struma.

In Hoofdstuk 2 wordt het onderzoek beschreven waarin de waarde werd onderzocht van een "tweede generatie" immuno-radiometrische assay (IRMA) voor TSH als een initieel schildklierfunctie onderzoek. Dit onderzoek werd uitgevoerd bij 36 patiënten bij wie het vermoeden op hyperthyreoïdie bestond. Zeventien van deze patiënten hadden een subnormale respons in een TRH-test (stijging van TSH, gemeten met een radio-immuno assay (RIA), minder dan 1.0 $\mathrm{mU} / \mathrm{l})$. Bij een discriminatiegrens van $\mathrm{TSH}=0.1 \mathrm{mU} / \mathrm{l}$ bleek dat een basaal gemeten TSH-IRMA een zeer hoge voorspellende waarde had voor de uitkomst van de TRH-test (positief en negatief voorspellende waarde respectievelijk 1 en 0.95). Bij de patiënten met een normale respons in de TRH-test $(n=19)$ correleerde de basaal gemeten TSH-IRMA goed met de stijging van TSH (gemeten d.m.v. RIA) na TRH stimulatie $(\mathrm{y}=0.13+0.13 \mathrm{x} ; \mathrm{r}=0.897 ; \mathrm{P}<$ 0.001 ). Op grond van deze gegevens werd de diagnose "subklinische hyperthyreodie" gedefinieerd als een combinatie van een onderdrukte basaal gemeten serum TSH concentratie (TSH $<0.1 \mathrm{mU} / \mathrm{l}$ ) en normale serum-concentraties van schildklierhormonen.

In Hoofdstuk 3 worden de relaties beschreven tussen serum osteocalcine, botdichtheid van de pols (gemeten door middel van "single photon absorptiometry") en parameters van de schildklierfunctie, leeftijd en lichaamsgewicht in een transversale studie betreffende 125 gezonde vrouwen tussen 21 en 75 jaar. Metingen in twee verschillende periodes in een jaar toonden geen verschil in serum-concentraties van osteocalcin, noch van schildklierfunctieparameters. De serum-concentratie van osteocalcine correleerde onafhankelijk met de leeftijd en de Queteletindex (osteocalcine $=9.774571+0.080023$ leeftijd ${ }^{(1)}$ 0.12621 Queteletindex ${ }^{(2)}$, multipele $\mathrm{r}=0.39 ; \mathrm{P}^{(1)}<0.0001, \mathrm{P}^{(2)}=0.013$ ). $\mathrm{Er}$ werden geen correlaties gevonden tussen osteocalcine en schildklierfunctieparameters. Omgekeerde correlaties tussen osteocalcine en zowel proximale als distale botdichtheid bleken te worden veroorzaakt door leeftijdsafhankelijke variaties in beide parameters. De beste correlatie tussen de serum osteocalcine- 
concentratie en de leeftijd werd verkregen met cubische regressie-analyse $(y=$ $\left.23.86536-1.080274 x+0.024269 x^{2}-0.000161 x^{3} ; r=0.39 ; P=0.0002\right)$. Ook de correlatie tussen distale, respectievelijk proximale, botdichtheid van de pols en de leeftijd werd het best beschreven met cubische regressie-analyse ( $y=$ $0.974144-0.002408 \mathrm{x}+0.000227 \mathrm{x}^{2}-0.000004 \mathrm{x}^{3} ; \mathrm{r}=0.59 ; \mathrm{P}<0.0001$, respectievelijk $y=1.506425-0.020131 x+0.000674 x^{2}-0.000007 x^{3} ; r=0.65$ $P<0.0001)$. Er werden geen onafhankelijke correlaties tussen de botdichtheid van de pols en parameters van de schildklierfunctie vastgesteld.

Concluderend blijkt dat bij gezonde vrouwen het niveau van de schildklierfunctie noch van invloed is op het botmetabolisme, noch op de botdichtheid. Aangezien de correlatie tussen de serum-concentratie van osteocalcine en de botdichtheid van de pols wordt veroorzaakt door leeftijds-afhankelijke schommelingen in beide parameters, wordt vastgesteld dat de serum concentratie van osteocalcine geen goede parameter is van de botdichtheid.

Hoofdstuk 4 betreft een studie waarbij de botdichtheid gemeten aan de pols van 23 vrouwen met subklinische hyperthyreoïdie en multinodulair struma wordt vergeleken met die van 54 vrouwen met euthyreoïde multinodulaire strumae. De gegevens werden uitgedrukt als Z-scores gerelateerd aan de waarden van de 125 gezonde vrouwen die in Hoofdstruk 3 werden beschreven. De patiënten met subklinische hyperthyreoïdie waren significant ouder dan de euthyreoïde patiënten (mediane (spreiding) leeftijd 57.2 (37-70.7 jaar) vs 48.6 (24-69.8 jaar; $\mathrm{P}<0.01)$ en zij hadden een significant hogere mediane (spreiding) serum concentratie FT4 (15.6 (11-23.2) vs 11.9 (8.3-18.3); $P<0.001)$. Bij de subklinische hyperthyreoïde patiënten bleek de gemiddelde $( \pm$ SEM) Z-score van zowel de distale als de proximale botdichtheid lager te zijn dan bij de euthyreoïde strumapatiënten $(-0.69 \pm 0.17$ vs $-0.1 \pm 0.18$; $P<0.05$, respectievelijk $-0.5 \pm 0.18$ vs $0.07 \pm 0.18 ; P<0.05$ ). In tegenstelling tot de euthyreoïde patiënten was bij de subklinisch hyperthyreoide patiënten FT4 omgekeerd gecorreleerd met de $Z$-scores van zowel de distale als de proximale botdichtheid van de pols $(r=-0.42 ; P<0.05$, respectievelijk $r=-0.45 ; P<0.05)$.

In Hoofstuk 5 wordt een vergelijking gemaakt tussen de serum-concentraties van osteocalcine en alkalische fosfatase van de patiënten die beschreven zijn in Hoofdstuk 4. Bij de subklinisch hyperthyreoilde patiënten waren zowel de mediane (spreiding) osteocalcine als de mediane (spreiding) alkalische fosfatase concentraties in serum hoger dan die van de euthyreoïde multinodulaire strumapatiënten $(12.4(6.7-19.6) \mu \mathrm{g} / \mathrm{l}$ vs $9.9(4.6-18.8) \mu \mathrm{g} / \mathrm{l} ; \mathrm{P}=0.01$, respectievelijk 74 (42-95) U/l vs $55(29-94) \mathrm{U} / \mathrm{P} \mathrm{P}=0.0034)$. Wanneer de osteocalcinewaarden werden uitgedrukt als Z-scores, bleek dat het verschil in de serum osteocalcine-concentraties niet werd veroorzaakt door het verschil in leeftijd tussen de twee groepen (mediane (spreiding) Z-score van osteocalcine van de 
subklinisch hyperthyreoïde vs de euthyreoïde strumapatiënten $0.33(-1.57$ tot $3.83)$ vs $-0.16(-2.84$ tot 3.13$) ; P=0.0225)$. Zowel bij de euthyreoïde als bij de subklinische hyperthyreoïde patinten was osteocalcine significant gecorreleerd met alkalische fosfatase $(r=0.51 ; P<0.001$, respectievelijk $r=0.45 ; P=$ 0.0313 ). Deze gegevens wijzen erop dat de botombouw van vrouwen met subklinische hyperthyreoildie en multinodulair struma verhoogd is vergeleken met die van euthyreoïde multinodulaire strumapatiënten.

In Hoofdstuk 6 wordt een onderzoek beschreven waarin enkele cardiale invloeden van endogene subklinische hyperthyreoïdie werd onderzocht in een transversale studie bij 27 vrouwen met subklinische hyperthyreoïdie en multinodulair struma in vergelijking met 27 vrouwen met euthyreoïde multinodulaire strumae. Systolische tijdsintervallen, uitgedrukt als de ratio van de pre-ejectie periode (PEP) en de linker ventriculaire ejectietijd (LVET), werden gemeten door middel van gelijktijdige registratie van het electrocardiogram en " $M$ mode" echocardiogram, gemeten met een twee-dimensionale echocardiograaf. Er werden geen significante verschillen waargenomen tussen de gemiddelde ( \pm SD) PEP/LVET ratio's van de twee groepen $(0.266 \pm 0.049$ vs $0.281 \pm 0.048$; N.S.). De gemiddelde ( $\pm \mathrm{SD}$ ) hartfrequentie in rust was echter hoger bij de subklinisch hyperthyreoïde dan bij de euthyreoïde multinodulaire strumapatiënten ( $89.7 \pm 12.9$ slagen $/ \mathrm{min}$ vs $80 \pm 14.4$ slagen $/ \mathrm{min} ; \mathrm{P}=0.012$ ).

In Hoofdstuk 7 worden enkele longitudinale gegevens gepresenteerd betreffende het botmetabolisme en de botdichtheid van de pols bij 8 postmenopausale vrouwen met subklinische hyperthyreoïdie en multinodulair struma tijdens monotherapie met methimazol. Deze gegevens werden vergeleken met die welke werden verkregen bij 8 onbehandelde postmenopausale vrouwen met dezelfde aandoening. Dit vervolgonderzoek beslaat een tijdsduur van 24 maanden. Thyreostatische behandeling van de 8 menopausale vrouwen resulteerde in een snelle daling van de hydroxyproline-uitscheiding in de urine. Er werden geen significante verschillen in de serum-concentraties van osteocalcine en alkalische fosfatase, noch in de calciumuitscheiding in de urine waargenomen. In de behandelde groep veranderde de botdichtheid van de pols niet gedurende de studieduur. In de onbehandelde groep trad echter een geleidelijke daling van de botdichtheid op, die significant $(\mathrm{P}<0.05)$ was voor de distale meting. Hieruit blijkt dat het botverlies van postmenopausale vrouwen met subklinische hyperthyreoïdie en multinodulair struma afgeremd kan worden door thyreostatische behandeling met methimazol, terwijl het botverlies doorgaat als de subklinische hyperthyreoïdie niet wordt behandeld.

De onderzoeken beschreven in dit proefschrift tonen aan dat "subklinische" hyperthyreoïdie niet wezenlijk verschilt van "manifeste" hyperthyreoïdie en als zodanig behandeld zou moeten worden. 


\section{NAWOORD}

Het onderzoek beschreven in dit proefschrift werd uitgevoerd in het Slingeland Ziekenhuis te Doetinchem. De patiënten en vele vrijwilligsters die bereid waren deel te nemen aan dit onderzoek ben ik zeer erkentelijk.

Met grote waardering voor zijn vele opvallende kwaliteiten wil ik Professor dr. A.C. Nieuwenhuijzen Kruseman bedanken. Door zijn enthousiasmerende begeleiding heb ik aan dit onderzoek veel vreugde beleefd en heeft niet de zo gevreesde "promotie-onderzoeks-ontgoocheling" toegeslagen. Door zijn scherp-analytisch vermogen, efficiënte werkwijze en zijn stuurmanskunst de hoofdlijn consequent te blijven volgen, is de tijdsbesteding in hoge mate effectief geweest, zodat het mogelijk was dit proefschrift te volbrengen naast een praktijk als internist zonder dat het aantal uren slaap beneden een kritisch minimum daalde.

Dr. F.J.L. Reijnders stond mij letterlijk als een "auctor intellectualis" bij ter plaatse van het onderzoek, in Doetinchem. Zeer erkentelijk ben ik hem voor de stimulerende discussies en zijn daadwerkelijke hulp bij de uitvoering van het onderzoek. Zijn nauwgezetheid was van een grotere orde dan ik tevoren had vermoed. Zijn kritisch oordeel getuigde ervan dat hij zich, als gynaecoloog goeddeels onbekend met de materie, serieus in het onderwerp heeft verdiept.

Mijn collega H. Drost ben ik zeer erkentelijk voor zijn aandeel in de uitvoering van het onderzoek naar de cardiale invloed van subklinische hyperthyreoidie en zijn relativerende, nuchtere kritiek.

Het personeel van de Interne functie-afdeling van het Slingeland Ziekenhuis te Doetinchem verrichtte zonder enig eigenbelang de vele botdensitometrieën. Els, Els, Rini, Riny, Anja, Karin, Lydia, Marlie en Annemie, ik ben jullie hiervoor zeer erkentelijk.

H. Jonkers en A.J. Bastiaanse wil ik bedanken voor de vele biochemische bepalingen die zij, mede met behulp van het personeel van het Isotopenlaboratorium, hebben verricht.

Janny Schuurman-van Valburg en Letty Hendriks-Bouwmeester ben ik zeer veel dank verschuldigd voor het typewerk, waarmee zij uiteindelijk na vele versies tot op de komma's en punten nauwkeurig het werk hebben volbracht.

De direktie van het Slingeland Ziekenhuis te Doetinchem, ten tijde van het onderzoek drs. Fr.C.A. Jaspers en dr. L. Weeda, ben ik erkentelijk voor de geboden faciliteiten. 
Dr. A.P.M. van Oudheusden ben ik zeer erkentelijk voor zijn kritische opmerkingen en het geboden onderdak in Rekem.

Tenslotte wil ik Ada Mudde-Groot, mijn echtgenote, bedanken, voor haar non-oppressieve steun; omdat het niet hoefde en omdat het toch kon. 


\section{CURRICULUM VITAE}

Naam:

Aart Hendrik Mudde.

Geboren:

20 juli 1954 te Eindhoven.

Burgelijke staat:

gehuwd, 1 dochter, 2 zoons.

Middelbare school:

1966 - 1972; gymnasium $\beta$, Eindhovens Protestants Lyceum, te Eindhoven.

Studie geneeskunde:

september 1972 - maart 1980; Vrije Universiteit, te Amsterdam.

Opleiding tot internist:

mei 1980 - april 1984; Sint Elisabeth's of Groote Gasthuis te Haarlem, hoofd opleiding: dr.L.van Beugen.

april 1984 - mei 1985; Academisch Ziekenhuis Leiden, te Leiden, vakgroep endocrinologie; hoofd opleiding: prof.dr. J.J. Veltkamp, hoofd vakgroep: prof.dr. H.M.J. Krans.

Aanvullende scholing:

mei 1985 - juli 1986; Academisch Ziekenhuis Leiden, te Leiden, afdeling experimentele endocrinologie, "balans-afdeling", vakgroep endocrinologie; hoofd afdeling: prof.dr. O.L.M. Bijvoet.

Registratie aandachtsgebied endocrinologie:

1 mei 1991.

Huidige functie:

vanaf 1 juli 1986; internist, Slingeland Ziekenhuis, te Doetinchem. 
